UNIVERSIDADE DE SÃO PAULO

ESCOLA DE ENFERMAGEM DE RIBEIRÃO PRETO

\author{
LEONARDO MARTINS KEBBE
}

\title{
DESEMPENHO DE ATIVIDADES E IMAGEM CORPORAL: REPRESENTAÇÕES SOCIAIS DE UM GRUPO DE MULHERES COM CÂNCER DE MAMA
}

Tese apresentada à Escola de Enfermagem de Ribeirão Preto da Universidade de São Paulo para obtenção do Título de Doutor em Enfermagem em Saúde Pública. Área de Concentração: Enfermagem em Saúde Pública. Linha de pesquisa: Assistência à Saúde da Mulher no Ciclo Vital.

Ribeirão Preto

2006 
UNIVERSIDADE DE SÃO PAULO

ESCOLA DE ENFERMAGEM DE RIBEIRÃO PRETO

\author{
LEONARDO MARTINS KEBBE
}

\title{
DESEMPENHO DE ATIVIDADES E IMAGEM CORPORAL: REPRESENTAÇÕES SOCIAIS DE UM GRUPO DE MULHERES COM CÂNCER DE MAMA
}

\begin{abstract}
Tese apresentada à Escola de Enfermagem de Ribeirão Preto da Universidade de São Paulo para obtenção do Título de Doutor em Enfermagem em Saúde Pública. Área de Concentração: Enfermagem em Saúde Pública. Linha de pesquisa: Assistência à Saúde da Mulher no Ciclo Vital.
\end{abstract}

Orientadora:

Profa. Dra. Ana Maria de Almeida

Ribeirão Preto

2006 


\begin{abstract}
AUTORIZO A REPRODUÇÃO E DIVULGAÇÃO TOTAL OU PARCIAL DESTE TRABALHO, POR QUALQUER MEIO CONVENCIONAL OU ELETRÔNICO, PARA FINS DE ESTUDO E PESQUISA, DESDE QUE CITADA A FONTE.
\end{abstract}

\title{
FICHA CATALOGRÁFICA
}

Kebbe, Leonardo Martins

Desempenho de atividades e imagem corporal: representações sociais de um grupo de mulheres com câncer de mama. Ribeirão Preto, 2006.

$$
158 \text { p. : il. ; } 30 \mathrm{~cm}
$$

$\underline{\text { Tese de Doutorado, apresentada à Escola de Enfermagem de }}$ Ribeirão Preto.

Orientador: Almeida, Ana Maria de

1. Câncer de mama. 2. imagem corporal. 3. terapia ocupacional. 


\section{FOLHA DE APROVAÇÃO}

Leonardo Martins Kebbe

Desempenho de atividades e imagem corporal: representações sociais de um grupo de mulheres com câncer de mama.

Tese apresentada à Escola de Enfermagem de Ribeirão Preto da Universidade de São Paulo para obtenção do Título de Doutor em Enfermagem em Saúde Pública. Área de Concentração: Enfermagem em Saúde Pública. Linha de pesquisa: Assistência à Saúde da Mulher no Ciclo Vital.

\section{Aprovada em:}

\section{Banca Examinadora}

Prof $^{a}$. Dr ${ }^{\mathrm{a}}$. Ana Maria de Almeida

Instituição: EERP-USP Assinatura

Prof $^{a}$. Dra ${ }^{\mathrm{a}}$. Maria José Clapis

Instituição: EERP-USP Assinatura

Prof $^{a}$. Dr ${ }^{\mathrm{a}}$. Marysia Mara Rodrigues do Prado de Carlo

Instituição: FMRP-USP Assinatura

Prof ${ }^{\mathrm{a}}$. Dr ${ }^{\mathrm{a}}$. Regina Yoneko Dakuzaku Carretta

Instituição: FMRP-USP Assinatura

Prof ${ }^{\mathrm{a}}$. Dr ${ }^{\mathrm{a}}$. Clícia Valim Côrtes Gradim

Instituição: UNIFAL-MG Assinatura 


\section{DEDICATÓRIA}

Aos meus pais, Elza e Eduardo, companheiros desta e de todas as outras trajetórias por mim percorridas, pelo incentivo, apoio, estímulo e afeto incondicional.

Aos meus irmãos Eduardo e Soraya, que embora distantes, mantiveram-se próximos e afetivos, compreendendo minha ausência durante a elaboração deste trabalho.

Aos tios Vitor, Ivone, Jorge e Isabel, pilares de sustentação, sem os quais a construção deste estudo teria sido mais difícil.

Aos colegas terapeutas ocupacionais, Cláudia, Débora, Ana Cláudia, Vânia, Maria Paula e Heloísa, que suavizaram os vários momentos de angústia nesse meu processo, talvez por compreenderem que o trabalho produtivo, quando exacerbado, impede o lazer e interfere no autocuidado...

Aos companheiros de todos os dias, Eduardo, Débora, Cláudia, Rosana, Rogério e Anderson, pela força e apoio prestados.

Às mulheres assistidas no REMA, por me ensinar que a vida pode ser mais bela, apesar das intempéries. 


\section{AGRADECIMENTOS}

À Dra ${ }^{\mathrm{a}}$. Ana Maria de Almeida, que no compartilhar deste árduo trabalho, se fez presente

de diversas formas: orientando, emprestando livros, ensinando, apoiando.

A você, minha admiração, respeito e gratidão! 
Às grandes mulheres que participaram deste estudo, embora algumas não estejam mais aqui, com sua simplicidade, coragem e sabedoria oportunizaram-me aprender que nessa passagem pela vida, temos de valorizar tudo aquilo que nos é dado. 


\section{AGRADECIMENTOS}

A Dra . Maria José Clapis e Ana Márcia Nakano, pelas contribuições inestimáveis no processo de qualificação deste, então, "projeto" de pesquisa.

À Dr ${ }^{a}$ Marli Villela Mamede, pelas importantes sugestões, na pré-avaliação desta tese. A você, meu respeito e admiração.

Às docentes que contribuíram para a finalização deste estudo: Dra ${ }^{\mathrm{a}}$ Clícia, Regina e Marysia, meu muito obrigado!

À $\operatorname{Dr}^{\mathrm{a}}$ Adriana Sparenberg Oliveira, que me possibilitou chegar até aqui, oportunizando minha entrada no REMA.

À Antonieta, pela disponibilidade, competência, afeto e respeito, características que a fazem muito especial.

À Cíntia, por ter compartilhado de todo o processo de elaboração deste trabalho, sem poupar esforços para auxiliar-me nas muitas horas de necessidade. 
Às colegas do REMA, Lenita, Vânia, Larissa e Fabrícia, pelo carinho e pela forma com que se doam na assistência às mulheres com câncer de mama.

À Bernadete e Lourdes, pela disponibilidade de ajuda oferecida, em diversos momentos, na sala de leitura da Escola de Enfermagem da USP.

A todas as pessoas, da vida real e da ficção, que me ensinaram a buscar e tentar vencer desafios. 


\section{SUMÁRIO}

RESUMO

ABSTRACT

RESUMEN

1. APRESENTAÇÃ

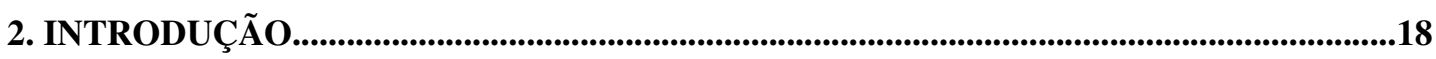

2.1 Considerações sobre o câncer de mama e a problemática da doença para a mulher..........18

2.2 A imagem corporal feminina após o câncer de mama..................................................................... 23

2.2.1 A avaliação da imagem corporal .............................................................................................................. 29

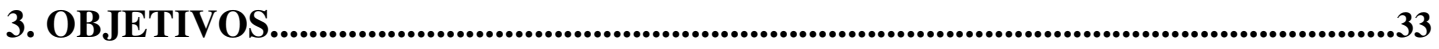

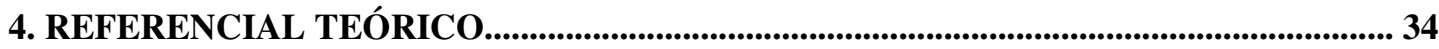

4.1 Fundamentos teóricos da Teoria das Representações Sociais ................................................. 34

4.1.1. A Teoria das Representações Sociais .......................................................................................... 37

4.1.2. As representações sociais e suas funções...................................................................................... 39

4.1.3. Formação das Representações Sociais .............................................................................. 39

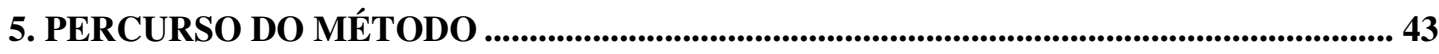

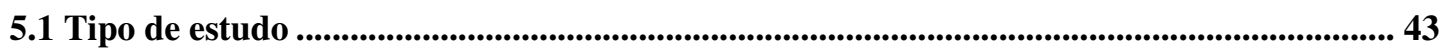

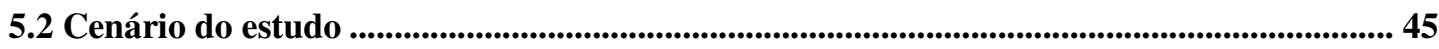

5.3 Sujeitos do estudo................................................................................................................................46

5.4 Inserção do pesquisador no campo de estudo ................................................................................. 47

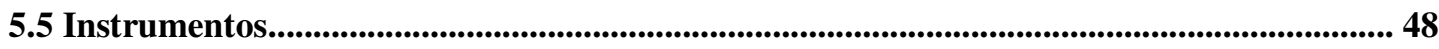

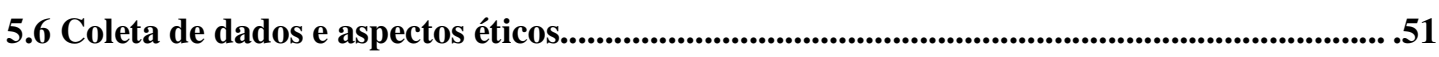

5.7 Descrição das oficinas de reflexão com as mulheres estudadas ................................................. 52

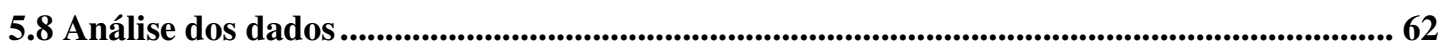

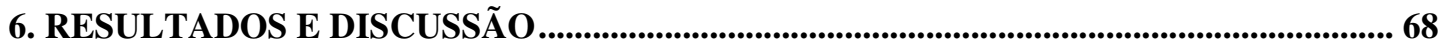

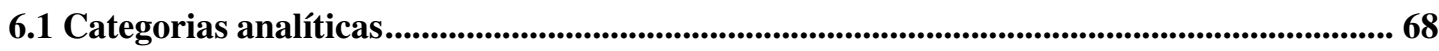

6.1.1 Corpo e tratamento.............................................................................................................................. 68

6.1.2 Corpo e fazer............................................................................................................................................105

6.1.2.1 Atividades da vida diária (AVDs) ................................................................................................. 105

6.1.2.2 Atividades produtivas e do trabalho ............................................................................................. 117

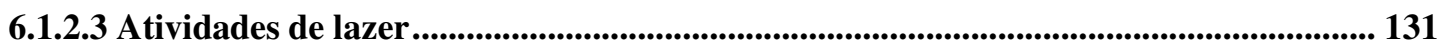

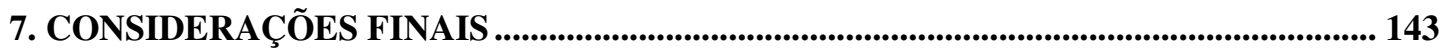

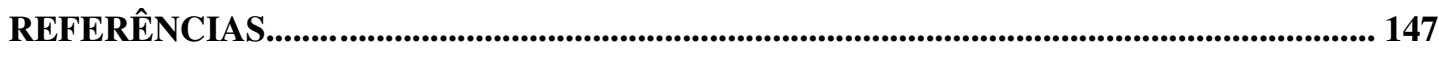

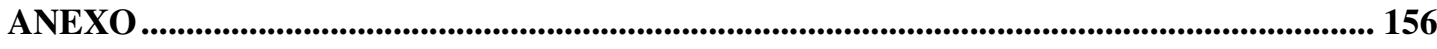

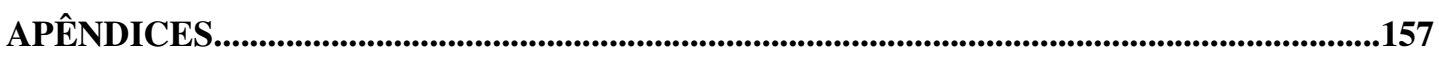


KEBBE, L. M. Desempenho de atividades e imagem corporal: representações sociais de um grupo de mulheres com câncer de mama. 2006. 158 f. Tese (Doutorado em Enfermagem em Saúde Pública)- Escola de Enfermagem de Ribeirão Preto da Universidade de São Paulo, Ribeirão Preto, São Paulo, 2006.

\section{RESUMO}

Este estudo teve como objetivo conhecer as representações sociais de mulheres tratadas por câncer mamário acerca da imagem corporal e suas repercussões no desempenho ocupacional. O referencial teórico utilizado foram as Representações Sociais na perspectiva das Ciências Sociais. Participaram deste estudo oito mulheres submetidas a diferentes modalidades cirúrgicas, como mastectomia, quadrantectomia e nodulectomia. Os dados foram coletados por meio de quatro encontros grupais elaborados para a discussão dos seguintes temas: 1) corpo e cirurgia; 2) corpo e atividades da vida diária; 3 ) corpo e trabalho e 4) corpo e lazer. Para a análise dos dados foi utilizada a técnica de análise temática de conteúdo, que possibilitou a emergência de duas categorias de análise: 1) corpo e tratamento, em que as mulheres representaram alterações na aparência do corpo, corpo limitado e sentimentos de fragilidade e revolta, independentemente da modalidade cirúrgica a que foram submetidas; 2) corpo e fazer, em que as mulheres representaram alterações no desempenho de atividades da vida diária, da produtividade e do lazer. As dificuldades associadas à realização das atividades assinalaram para a presença de uma imagem corporal distorcida mediante a percepção de um corpo modificado em sua aparência e funcionalidade, levando as mulheres a sentirem-se incapazes, denotando o câncer de mama como uma doença estigmatizante. Os dados evidenciaram que a continuidade das atividades se fez para a desconstrução do estigma da doença e para a manutenção dos papéis sociais das mulheres, predominantemente associados aos cuidados do lar e de familiares, revelando valores assimilados por elas de uma sociedade pautada em uma cultura androcêntrica.

Palavras-chave: câncer de mama, imagem corporal, terapia ocupacional 
KEBBE, L. M. Activities performance and body image: social representations of a group of women with breast cancer. Ribeirao Preto SP, $2006158 \mathrm{f}$ ( doctor degree in Nursing in Public Health) Ribeirao Preto School of Nursing from the University of Sao Paulo, Ribeirao Preto, Sao Paulo, 2006.

\section{ABSTRACT}

The objective of the study was to know the social representation of breast cancer treated women about the body image and its effects in the occupational performance. The theoretical referencial used was the social representation in the perspective of social sciences. Eight women who have undergone different surgery types such as radical mastectomy and breast conserving surgery participated from the study. The data were collected through four group meetings elaborated for the discussion of the following themes: 1) body and surgery and 2) body and everyday life activities 3) body and work and 4) body and leisure. To analyse the data it was used the content thematic analyses technique which made possible the appearance of two analyses categories: 1) body and treatment, in which women showed alterations in the body aspect, limited body and feelings of fragility and revolt, despite the surgery type they had been through. 2) Body and activities doing, in which women showed alterations in the performance of everyday life activities, productivity and leisure, the difficulties associated to the accomplishment of everyday activities stressed the presence of a distorted body image in view of the perception of a modified body in its aspect and functional way causing the women to feel not capable, showing breast cancer as a stigmatizing disease. The data made it clear that the continuation of everyday life was used to erase the stigma of the disease and for the maintenance of the women's social roles, entirely related to home and family care, revealing values assimilated by them of a society based on masculine values.

Key-words: breast cancer, body image, occupational therapy 
KEBBE, L. M. Desempeño de las actividades y imagen corporal: representaciones sociales de un grupo de mujeres con cáncer de mama. 2006. 158 f. Tesis (Doctorado em Enfermería en Salud Pública)- Escuela de Enfermería de Ribeirão Preto de la Universidad de São Paulo, Ribeirão Preto, São Paulo, 2006.

\section{RESUMEN}

Este estudio tuvo como objetivo conocer las representaciones sociales de mujeres tratadas por cáncer mamário acerca de la imagen corporal y sus repercusiones en el desempeño ocupacional. El referencial teórico utilizado fue Representaciones Sociales en la perspectiva de las Ciencias Sociales. Participaron de este estudio ocho mujeres sometidas a diferentes modalidades cirúrgicas, como mastectomía radical, cuadrantectomía y nodulectomía. Los datos fueron colectados por medio de cuatro encuentros grupales elaborados para la discusión de los siguientes temas: 1) cuerpo y cirugía; 2) cuerpo y actividades de la vida diária; 3) cuerpo y trabajo y 4) cuerpo y lazer. Para el análisis de los datos fue utilizada la técnica de análisis temática de contenido, que posibilitó el surgimiento de dos categorias de análisis: 1) cuerpo y tratamiento, en que las mujeres representaron alteraciones en la apariencia del cuerpo, cuerpo limitado y sentimientos de fragilidad y revuelta, independentemente de la modalidad cirúrgica a que fueron sometidas; 2) cuerpo y hacer, en que las mujeres representaron alteraciones en el desempeño de actividades de la vida diária, de la produtividad y del lazer. Las dificultades asociadas a la realización de las actividades apuntaron para la presencia de una imagen corporal distorcida mediante la percepción de un cuerpo modificado en su apariencia y funcionalidad, llevando las mujeres a sentirse incapaces, denotando el cáncer de mama como una enfermedad estigmatizante. Los datos evidenciaron que la continuidad de las actividades se dió para la desconstrucción del estigma de la enfermedad y para el mantenimiento de los papeles sociales de las mujeres, predominantemente asociados a los cuidados del hogar y de familiares, revelando valores asimilados por ellas de una sociedad pautada en una cultura androcéntrica.

Palabras claves: cáncer de mama, imagen corporal, terapía ocupacional 


\section{APRESENTAÇÃO}

Graduei-me em Terapia Ocupacional no ano de 1997 pela Universidade Federal de São Carlos, ano em que realizei atividades de estágio profissionalizante junto ao Núcleo de Ensino, Pesquisa e Assistência na Reabilitação de Mastectomizadas (REMA) do Departamento Materno Infantil e Saúde Pública da Escola de Enfermagem de Ribeirão Preto da Universidade de São Paulo.

Neste período, a perspectiva de atuar junto à equipe multiprofissional do Núcleo foi um desafio, pois a atuação clínica da Terapia Ocupacional na reabilitação de mulheres com câncer de mama era desconhecida naquele contexto e também para mim, que não havia tido experiência anterior de trabalho com aquela clientela.

Esta dificuldade foi reforçada pela constatação de que as bases teóricas referentes à prática profissional do terapeuta ocupacional na reabilitação de pacientes com câncer de mama era praticamente inexistente, dificultando a elaboração de uma abordagem fundamentada e pertinente às necessidades das pacientes que freqüentavam o REMA.

Embora inicialmente tenha me deparado com obstáculos na delimitação de uma prática clínica específica de Terapia Ocupacional para mulheres com câncer mamário, as atividades do estágio possibilitaram-me entender o câncer de mama como uma doença complexa e de múltiplas conseqüências para as mulheres assistidas naquele serviço, envolvendo-as em suas dimensões biológicas, psicológicas, emocionais e sociais. Isto me fazia considerar o REMA como um espaço promissor e oportuno à inserção da Terapia Ocupacional, uma vez que a assistência oferecida às pacientes se apoiava em bases filosóficas semelhantes à desta profissão, no sentido de se buscar a compreensão e a assistência integral do ser humano, neste caso a mulher mastectomizada em uma perspectiva biopsicossocial.

$\mathrm{Na}$ busca de conhecer melhor as diferentes experiências vividas pelas mulheres com câncer de mama e na tentativa de apreender a dimensão da doença em suas vidas, tenho participado das atividades do REMA nos últimos nove anos desde a conclusão da graduação. Desta experiência, foram muitos os aspectos por mim aprendidos sobre as diversas possibilidades de se assistir às mulheres com câncer de mama, oportunizados pelo convívio com a equipe atuante no serviço. 
Como terapeuta ocupacional, tenho buscado compreender a forma pela qual o câncer de mama, as diferentes modalidades de tratamentos, como a cirurgia e suas conseqüentes limitações, interferem na vida de atividades destas mulheres, sejam aquelas relacionadas ao auto-cuidado, trabalho ou lazer e por entender que recolocar o indivíduo em sua vida ativa constitui uma das principais finalidades da Terapia Ocupacional.

Assim, tenho estado especialmente atento aos relatos das pacientes que participam da dinâmica de trabalhos com grupos de apoio do REMA, relacionados às queixas, às preocupações e mesmo à satisfação no desempenho de suas atividades diárias, o que tem sido para mim fonte de constantes reflexões e questionamentos.

Observo que as pacientes recém chegadas ao REMA tendem a focalizar preocupações na própria sobrevivência, expressando seu medo e angústia diante da possibilidade da recidiva do câncer e questionando a eficácia do tratamento, seja em relação à cirurgia ou mesmo à quimioterapia e radioterapia, apontando ainda as dificuldades sentidas com os efeitos colaterais destas últimas.

Parte dessas pacientes também expressa muitas dúvidas quanto as reais possibilidades de continuarem a realizar as atividades domésticas, profissionais ou de lazer que desenvolviam antes da cirurgia, cessado o período de tratamento, e são prontamente esclarecidas pelos profissionais da equipe do REMA sobre os cuidados necessários para que isto ocorra sem causar-lhes maiores prejuízos funcionais.

Nesses momentos as mulheres são orientadas sobre a possibilidade de retorno gradual às atividades diárias, devendo-se evitar exageros durante a realização das tarefas domésticas, principalmente, o que poderia predispô-las ao surgimento do linfedema do braço.

A necessidade da adoção de cuidados para a prevenção do linfedema, durante as atividades, é outra orientação enfatizada pela equipe, principalmente para os casos de pacientes submetidas ao esvaziamento das cadeias de linfonodos ganglionares axilares. As orientações também atentam para a importância da realização de atividades físicas específicas para a melhora da postura e da amplitude articular dos membros superiores, comprometidas pela cirurgia.

De posse destas orientações, as pacientes costumam apontar o despreparo das equipes de saúde que as acompanhavam no período de internação para a realização da cirurgia até a alta hospitalar, responsabilizando-as pela desinformação acerca das 
orientações e cuidados a serem adotados para o retorno das atividades diárias, assim como em relação ao prognóstico da doença, o que as deixavam muito angustiadas.

Embora as orientações oferecidas pelos profissionais do REMA as tranqüilizassem nos momentos em que colocavam suas dúvidas, percebia, nos relatos destas pacientes, que a perspectiva de lidar concretamente com as alterações no desempenho de atividades devido às limitações físicas provocadas pela cirurgia era uma situação altamente ameaçadora e preocupante.

Muitas pacientes acreditavam na impossibilidade de retorno satisfatório às suas atividades relacionando essa dificuldade às alterações físicas e emocionais provocadas pela cirurgia e pelo tratamento, por vezes considerada por elas como mutiladora tornando-as diferentes das outras mulheres, seja em relação ao próprio corpo ou em seus aspectos psicológicos.

Nesses momentos, chamava a atenção os depoimentos de pacientes que questionavam seu valor pessoal e seu papel como mulher diante dessas mudanças relacionadas ao fazer, o que lhes acentuava as dificuldades de adaptação a um novo corpo exigente de cuidados que poderiam alterar, em certa medida, seu desempenho de atividades e, conseqüentemente, seus diferentes papéis sociais.

Algumas mulheres referiam sentirem-se expostas no convívio com familiares, amigos e colegas do trabalho, principalmente pelas dificuldades vivenciadas durante a execução de suas tarefas domésticas e profissionais. Comentavam sentir o corpo diferente, no sentido de não responder satisfatoriamente às exigências das diferentes ocupações que desenvolviam antes da cirurgia, fato que também as deixavam angustiadas diante do pensamento de que as pessoas com as quais conviviam pudessem tratá-las de modo diferente.

No processo de compartilhar as dificuldades vividas pelas mulheres com câncer de mama que chegavam ao REMA, freqüentemente indagava que repercussões as alterações da imagem corporal traziam na realização de suas atividades da vida diária (AVDs), de lazer e de produtividade? Que tipo de valorização as mulheres atribuíam ao seu fazer? Que estratégias adotavam para lidar com esta problemática? Qual o significado destas dificuldades vividas por elas? Como pensavam sua nova condição e que sentimentos lhes suscitavam? Como acessar adequadamente estas questões nas mulheres assistidas no serviço? 
Estas reflexões estimularam-me a elaboração do presente estudo, com vistas a buscar respostas que possibilitem contribuir para instrumentalizar melhor minha prática profissional, assim como a de outros profissionais e serviços envolvidos na assistência a mulheres com câncer de mama.

Considero importante destacar, no que tange à Terapia Ocupacional, que os referenciais teóricos específicos da atuação desta profissão com mulheres com câncer mamário, em processo de reabilitação, ainda é escasso, o que continua a ser um desafio para a prática clínica com esta clientela, embora exista um início de produção científica versando sobre a atuação terapêutico-ocupacional para essas mulheres, a exemplo dos trabalhos de Hinman (2002), Pengo e Santos (2004), Shearsmith (2001) e Vockins (2004).

Embora esses trabalhos se focalizem na descrição de abordagens voltadas para a reabilitação física e para o tratamento do linfedema de braço em mulheres tratadas por câncer das mamas, existe menção sobre a necessidade de se atentar para as questões da imagem corporal dessa clientela e suas conseqüências para o desempenho ocupacional. Apontam, nesse sentido, a importância de se contemplar também as questões psicossociais das pacientes envolvidas no tratamento.

Em Terapia Ocupacional, o conceito de desempenho ocupacional está associado à capacidade dos indivíduos de realizar tarefas que possibilitem o desempenho de papéis ocupacionais, em conformidade com sua faixa etária, cultura e ambiente. Estes papéis ocupacionais desenvolvem-se conjuntamente com as ocupações que o indivíduo desempenha em diferentes contextos sociais, a exemplo dos papéis de dona de casa, estudante, trabalhador, pai ou mãe, entre outros (PEDRETI; EARLY, 2004).

As ocupações são definidas como coisas comuns e familiares que as pessoas fazem no dia a dia, consideradas, também, como sendo as atividades que dão sentido à suas vidas (EARLY, 2004; NEISTADT; CREPEAU, 2002).

As ocupações contribuem para o senso de identidade das pessoas, o que se torna evidente quando estas se definem, comumente, por meio de suas diferentes ocupações que desenvolvem nos cenários do trabalho, lazer ou da vida diária. Nesse sentido, o acometimento de doença que acarrete em incapacidades físicas e psicossociais, de forma temporária ou permanente, ameaça a identidade de uma pessoa (EARLY, 2004).

$\mathrm{Na}$ internalidade da Terapia Ocupacional, as atividades da vida diária (AVDs), as atividades produtivas e de trabalho e as atividades de lazer configuram as áreas de 
desempenho ocupacional. O desempenho em ocupações pode, ainda, ser considerado de acordo com os componentes de desempenho, tidos como as habilidades ou funções que apóiam a capacidade para o desempenho, a exemplo da força muscular, equilíbrio, memória, habilidades psicossociais e psicológicas, entre outras. As ocupações também se efetivam em contextos de desempenho, que consideram dimensões temporais e ambientais. (EARLY, 2004; PEDRETI; EARLY, 2004).

No contexto de desempenho, a dimensão temporal é dada por características como a idade, o estágio de desenvolvimento do indivíduo e sua condição clínica. A dimensão ambiental engloba o ambiente físico, como a residência do indivíduo, mobília, edificações e os diferentes objetos. $\mathrm{O}$ ambiente social também é considerado, constituindo-se no grupo de pessoas significativo para o indivíduo, sendo os costumes, crenças, comportamentos, oportunidades de educação, entre outros, constituintes de seu ambiente cultural (PEDRETI; EARLY, 2004).

Neste estudo, a problemática vivenciada pelas mulheres tratadas por câncer das mamas será abordada de acordo com as três áreas de desempenho ocupacional (AVDs; atividades produtivas e do trabalho; atividades de lazer).

A opção por esse recorte se deu por entendermos que as atividades humanas se efetivam nestas três áreas sendo, a doença oncológica e seu tratamento, responsáveis por mudanças no desempenho ocupacional, visto comprometer a integridade física e psicossocial de mulheres tratadas por câncer mamário.

A introdução que se segue busca situar teoricamente o câncer de mama e suas possibilidades terapêuticas, apontando a problemática da doença para a mulher, incluindo as questões relativas à imagem corporal, pós-tratamento. 


\section{INTRODUÇÃO}

\subsection{Considerações sobre o câncer de mama e a problemática da doença para a mulher}

Nos países ocidentais, atribui-se ao câncer de mama uma das principais causas de morte em mulheres, sendo considerado o tipo de câncer mais temido devido a alta freqüência e aos efeitos psicológicos que afetam a percepção da sexualidade e imagem corporal.

Tanto em países desenvolvidos como nos países em desenvolvimento, as estatísticas mostram aumento na freqüência do câncer de mama. Durante as décadas de 60 e 70, a Organização Mundial da Saúde (OMS) registrou um aumento de dez vezes nas taxas de incidência da doença, em diversos continentes (BRASIL, 2006).

Nos Estados Unidos, de acordo com a Sociedade Americana de Cancerologia, há previsão de que uma entre dez mulheres desenvolva câncer de mama ao longo da vida. No Brasil, entre os diferentes tipos de câncer, o de mama é apontado como aquele que mais causa a morte entre as mulheres. Em 2000, foram registradas 8.390 mortes por câncer de mama e, para 2006, existe previsão para se diagnosticar 48.930 casos novos (BRASIL, 2006).

As possibilidades terapêuticas mais comuns para o tratamento do câncer de mama são a cirurgia, radioterapia associada à cirurgia ou como tratamento único para casos avançados, hormonioterapia e quimioterapia como tratamento paliativo ou adjuvante do tratamento cirúrgico. O estágio do câncer de mama irá determinar o tipo de procedimento cirúrgico a ser realizado, mas quaisquer destes tratamentos provocam alterações físicas que vão desde uma deformação mínima da mama até a perda completa do órgão, ruptura na integridade da pele, e ainda da drenagem linfática e venosa (ALMEIDA, 1997; GRADIM, 2005; PRADO, 2001).

Pengo e Santos (2004) descrevem os tipos de intervenção cirúrgica para o câncer das mamas, entre os quais:

1) Tumorectomia, seguida de dissecção dos linfonodos axilares e de radioterapia para o tecido mamário remanescente; 
2) Quadrantectomia, em que se procede à ressecção do quadrante mamário envolvido, dissecção dos linfonodos axilares, também radioterapia;

3) Mastectomia simples, caracterizada pela remoção do tecido mamário da clavícula à reborda costal e da linha médio-external, até a borda lateral do músculo grande dorsal;

4) Mastectomia radical modificada de Pattey, em que o tecido mamário é retirado em sua totalidade junto com os linfonodos axilares. $\mathrm{O}$ músculo peitoral menor é retirado e o maior, conservado;

5) Mastectomia radical de Halsted, na qual toda a mama é removida com os linfonodos axilares e os músculos peitorais maior e menor. Atualmente, esta técnica é utilizada nos casos em que o tumor infiltra o músculo peitoral maior;

6) Cirurgia Madden, na qual toda a mama é extirpada com os linfonodos axilares, sendo conservados os músculos peitorais maior e menor.

Os músculos e cadeias ganglionares retirados durante a cirurgia para câncer de mama colocam a mulher frente a complicações físicas passíveis de surgimento imediato ou tardio. Entre estas, podem ser identificadas hemorragia, lesão de nervos, diminuição de movimentos de ombro e braço, e o linfedema (MAMEDE, 1991).

O linfedema é uma complicação bastante freqüente após a cirurgia, sendo que toda paciente submetida à linfadenectomia axilar deveria ser orientada sobre a necessidade de se realizar exercícios de forma gradual, no período pós-operatório, com vistas à prevenção do mesmo e para a recuperação funcional do braço afetado (JUNQUEIRA JUNIOR; QUADROS; SANTOS, 1988).

Mamede (1991) considera a prática dos exercícios enquanto parte integrante dos procedimentos de reabilitação de mulheres com câncer de mama, visando a prevenção, diminuição ou eliminação do linfedema, dor e limitações articulares, entre outras necessidades. Refere que, para se buscar um trabalho efetivo de reabilitação dessas mulheres, há necessidade dos profissionais envolvidos conhecerem o tipo de cirurgia a qual a paciente foi submetida, assim como das estruturas extirpadas durante o referido procedimento, e suas conseqüências.

O linfedema constitui um incômodo de ordem física e emocional para as mulheres com câncer mamário, causando uma limitação de movimentos que as levam a reduzir as 
atividades produtivas que realizavam anteriormente à cirurgia, tanto no lar como no ambiente de trabalho. $\mathrm{O}$ edema do membro superior ameaça a intimidade e a imagem corporal das mulheres que, não raro, experimentam depressão e ansiedade, necessitando de apoio psicológico ou intervenção psiquiátrica (PANOBIANCO, 1998).

O diagnóstico e o tratamento de um câncer mamário não se restringe ao órgão afetado, pois a mulher é acometida física, emocional e socialmente, podendo apresentar alterações na imagem corporal, sendo sua recuperação dependente de como ela percebe seu corpo, do apoio familiar e de amigos, e das idéias construídas sobre a doença (ALMEIDA, 1997; GRADIM, 2005).

As mamas são órgãos atribuídos de significados importantes para a mulher, tanto físicos como psicológicos, pois constituem parte da estética feminina, além de exercerem papel na diferenciação de gênero. Relacionam-se ao ato de amamentar, sendo considerados símbolos da maternidade, denotando ainda aspectos ligados à expressão da feminilidade e ao potencial erógeno (CANTINELLI et al., 2006; HECKERT, 1995; KRYNSKI, 1986; YALOM, 1998).

As questões acima apontadas têm sido utilizadas como estratégia de mercado na publicidade, que ao valorizar mamas grandes e firmes e o corpo feminino em si, o torna alvo de "marketing" para a venda de produtos (GRADIM, 2005).

Assim, diante desta valorização social e cultural atribuída às mamas femininas, torna-se possível compreender que a realização de cirurgia para a retirada total ou parcial destes órgãos causa impacto psicológico relevante na mulher em decorrência de suas repercussões neste complexo universo de significados.

Pacientes com câncer de mama podem apresentar ansiedades e fantasias relacionadas à perda da capacidade de amamentar, também da obtenção de prazer sexual, além de prejuízos estéticos (WOLFF, 1996).

A literatura reporta-se às diversas manifestações psicológicas na mulher frente ao diagnóstico de câncer de mama, tais como sentimento de menos valia, depressão, raiva e culpa. O temor de serem abandonadas pelo companheiro ou tornarem-se objetos de piedade, além da recorrência do câncer e da presença de metástases também configuram como fontes de preocupação para a clientela. 
Entre as implicações psicossociais e comportamentais em mulheres com câncer de mama, encontram-se diminuição na freqüência de relações sociais e sexuais destas pacientes, em decorrência da alteração de imagem corporal (FRIES; REINHARD, 1996).

Mudanças na imagem corporal podem levar a mulher a isolar-se do convívio social, por sentir-se inadequada ou para preservar-se dos demais. Esse tipo de atitude acarretaria em prejuízos em suas atividades de lazer e da produtividade, a exemplo das tarefas domésticas e aquelas relativas ao trabalho fora do lar (WOLFF, 1996).

A duração do tratamento e a incerteza dos seus resultados são considerados fatores que afetam o desempenho ocupacional das mulheres, nas áreas do lazer e da produtividade, sendo oportuno atentar para a escassez de estudos sobre recursos terapêuticos a serem utilizados em casos de alterações das atividades desempenhadas por elas (DUARTE; ANDRADE, 2003; TULMAN; FAWCETT, 1990).

No que concerne às práticas de reabilitação com mulheres com câncer de mama, parte da literatura afirma a importância de integralização de suas necessidades físicas, psicológicas e sociais, mencionando alteração no desempenho ocupacional das pacientes, a exemplo do trabalho doméstico e remunerado, também do lazer, em decorrência das limitações na movimentação do braço ou da presença do linfedema (CARRILO; JAVIER, 1997; MAMEDE, 1991; PANOBIANCO, 1998; SALES et al., 2001; SHIMOZUMA et al. 1999).

Em consonância com a literatura científica, nossa prática profissional com mulheres com câncer mamário nos têm feito atentar para a importância da realização das suas atividades diárias, de forma moderada e graduada, como um estímulo para a movimentação do braço afetado, assim como para a necessidade de alguns cuidados especiais a serem considerados durante tais atividades, especialmente para aquelas pacientes que se submeteram ao esvaziamento axilar, entre os quais: evitar queimaduras, cortes, arranhões, injeções, carregar peso excessivo, exposição excessiva ao sol, esforços físicos excessivos entre outros (ALMEIDA, 1997; BRASIL, 2002; MAMEDE et al., 1999).

Sasaki e Lamari (1997), Schieroni et al., (1995) e Svatics (1998) reportam-se às alterações no desempenho ocupacional de mulheres com câncer de mama, concernentes às atividades de vida diária e do lazer, afirmando a necessidade dos profissionais de saúde atentarem a essas questões. 
O tratamento cirúrgico para o câncer de mama acarreta para a mulher diversas alterações de ordem física e emocional, também na imagem corporal e no desempenho ocupacional, sendo que o trabalho de reabilitação deve incluir exercícios para a recuperação da amplitude de movimentos do braço e do ombro (MAMEDE et al., 2000).

Apesar da literatura científica enfatizar as diferentes modalidades cirúrgicas e suas repercussões para a imagem corporal em mulheres com câncer mamário, autores como Mcphail e Wilson (2000) apontam para as repercussões do tratamento quimioterápico na imagem corporal, considerando seus efeitos adversos como alopecia e aumento de peso e fadiga, os quais, combinadamente, podem modificar os padrões de atividades das pacientes.

Entendendo que as diferentes formas de tratamento por câncer de mama, tais como a cirurgia e a quimioterapia, as limitações físicas dele decorrentes ou a presença do linfedema ameaçam a imagem corporal da mulher, envolvendo-a em seus aspectos funcionais, emocionais, sociais e no desempenho ocupacional, consideramos que a Terapia Ocupacional tem importante contribuição a oferecer a essas pacientes, quando objetiva facilitar a retomada de sua vida de atividades.

A Terapia Ocupacional se configura em uma área de conhecimento e prática de saúde interessada pelos problemas do homem em sua vida de atividades sendo, estas últimas, consideradas na internalidade da profissão como o produto e o meio de construção do próprio homem, buscando entender as relações que o mesmo, em seu fazer, estabelece em sua condição de vida e saúde (MEDEIROS, 2003).

A profissão de Terapia Ocupacional busca auxiliar as pessoas com possíveis incapacidades ou deficiências a realizarem as atividades diárias que são importantes para elas, sendo o termo "ocupação" compreendido como todas as atividades que ocupam o tempo das pessoas, dando sentido a suas vidas (NEISTADT; CREPEAU, 2002).

$\mathrm{Na}$ ótica da Terapia Ocupacional, tais atividades são divididas nas seguintes principais áreas de desempenho ocupacional: atividades da vida diária (AVD), incluindo o auto-cuidado, a manutenção da saúde, a socialização, a comunicação e mobilidade funcionais e ainda a expressão sexual; atividades profissionais e produtivas, entre as quais se inserem tarefas relacionadas a administração da casa e do dinheiro, do cuidado com os outros assim como atividades vocacionais referentes ao trabalho e, por fim, as atividades de diversão e lazer (NEISTADT; CREPEAU, 2002). 
Consideramos que, ao compreender as relações que as mulheres com câncer de mama estabelecem entre o desempenho de suas atividades e o significado que atribuem aos seus corpos físicos, que passaram por alterações, virá auxiliar os profissionais de saúde e em especial ao terapeuta ocupacional a direcionarem o planejamento de uma assistência que incorpore o mundo de atividades dessa clientela.

Partimos ainda do pressuposto de que o retorno às atividades é de extremo interesse para as mulheres com câncer de mama, mas que as alterações na imagem corporal provocadas pela cirurgia constitui-se em um importante fator impeditivo para que isto ocorra. Portanto, aprofundar o conhecimento nesta dimensão se torna imperativo.

\subsection{A imagem corporal feminina após o câncer de mama}

Por imagem do corpo humano entende-se a figuração de nosso corpo formada em nossa mente, ou seja, o modo pelo qual o corpo se apresenta para nós. Essa definição considera as expectativas investidas nesta imagem de corpo, seja em termos de sua aparência física ou funcionalidade. (SCHILDER, 1981).

O conceito de imagem corporal acima exposto apresenta características de subjetividade, por centrar-se na representação mental do indivíduo sobre seu próprio corpo, englobando múltiplas formas pelas quais o indivíduo o experiencia e o conceitua (BREDIN, 1999; TAVARES, 2003).

Esse processo depende de uma organização cerebral integrada, de fatores sensoriais, também de aspectos psicodinâmicos, embora dependa de uma estrutura orgânica concreta (o próprio corpo). A imagem corporal deve ser compreendida como um fenômeno singular, na medida em que se estrutura no contexto da experiência existencial e individual do ser humano, em um universo de inter-relações entre imagens corporais (TAVARES, 2003).

Schilder (1981) refere ser por meio dessa inter-relação entre imagens corporais que se dá a maior ou menor valorização e interesse dos indivíduos em determinadas partes dos seus próprios corpos e destes para com o de outros indivíduos, levando a uma associação entre a imagem que o sujeito tem de si e dos outros.

Os problemas com a imagem corporal são dados a partir uma discrepância acentuada entre a imagem de corpo figurada na mente do indivíduo com as expectativas 
nela depositadas (em termos de aparência e funcionalidade), sendo, tal discrepância, geradora de alterações no desempenho ocupacional dos sujeitos (SCHILDER, 1981; SHEARSMITH, 2001).

Tomando como base o que foi exposto, torna-se possível considerar que quaisquer alterações que comprometam o corpo, especialmente suas partes mais valorizadas culturalmente, levam o sujeito a uma inadaptação individual e social. Pois as expectativas nele investidas, quer seja pelo próprio indivíduo ou pelas pessoas com as quais convive necessitam ser repensadas e reajustadas.

Assim, reiteramos que este estudo, ao abordar mulheres que realizaram cirurgia por câncer de mama, possibilita desvelar diferentes significados de um corpo mutilado para elas e compreender como isto lhes interfere no desempenho ocupacional. O caráter de subjetividade envolvido nas alterações da imagem corporal e nas diferentes valorações conferidas ao seu fazer serão aqui levadas em conta, visto serem passíveis de diferentes representações.

Para a terapeuta ocupacional Shearsmith (2001) a imagem corporal de um indivíduo se desenvolve a partir da infância, sendo influenciada pelo contexto social e cultural em que vive. Constrói-se mediante experiências perceptivas e subjetivas que contribuem para o modo do indivíduo pensar, sentir e agir.

O impacto de uma doença que coloque em risco a vida humana pode resultar em mudanças físicas, psicológicas e sociais que alteram ou ameaçam drasticamente a imagem corporal de uma pessoa. A aparência do corpo, as crenças a ele atribuídas acerca das possíveis limitações e sobre o modo como interage com o meio podem acentuar as mudanças mencionadas, de forma permanente ou temporária, sendo expressas ou veladas pelos pacientes (SHEARSMITH, 2001).

Como apontado anteriormente, a modificação da imagem corporal em mulheres submetidas à cirurgia por câncer mamário as coloca diante de dificuldades de readaptação em seus relacionamentos interpessoais e no desempenho ocupacional (HARTCOURT; RUMSEY, 2001; WOLFF, 1996).

A mastectomia, procedimento mais comum como tratamento cirúrgico do câncer de mama, pode desconstruir a imagem corporal da mulher de forma abrupta, a qual necessitará de tempo para a assimilação e incorporação de seu novo corpo. A mastectomia é considerada um dos tratamentos mais comuns para o câncer de mama e a mutilação dela 
decorrente se traduz em muitas questões na vida das mulheres, especialmente aquelas relacionadas à imagem corporal. O modo sobre como a mulher percebe e lida com essa nova imagem corporal e como isso afeta sua existência constituem-se em inquietações para os profissionais que se propõe prestar uma assistência integral (FERREIRA; MAMEDE, 2003).

A amputação de qualquer parte externa ou interna do corpo é traumática, modificando a imagem corporal, a qual deve ser ajustada a essa nova situação. A experiência da mastectomia revela que as mulheres percorrem trajetórias diferentes quando retornam aos seus familiares e às suas atividades, mas ainda não há clareza como esse processo é vivido e interpretado por elas (FERREIRA; MAMEDE, 2003).

Assim, diante do exposto, consideramos que a alteração da imagem corporal resultante de cirurgia por câncer de mama é uma experiência bastante subjetiva para a mulher, portanto impossível de ser generalizada, pois está relacionada a fatores psicológicos, sociais e culturais, estando também associada ao tipo de procedimento cirúrgico a que foi submetida.

As técnicas cirúrgicas para a retirada total da mama afetada pelo câncer vem sendo substituídas por outras cirurgias que evitam a mutilação, tais como a quadrantectomia e lumpectomia, na tentativa de se preservar o corpo da paciente. Para os casos avançados de câncer, em que há necessidade da retirada completa da mama, existe atualmente a possibilidade de reconstrução do órgão com utilização de silicone ou do tecido abdominal (DUARTE; ANDRADE, 2003).

O desenvolvimento das técnicas de cirurgia plástica tem proporcionado resultados satisfatórios para a expectativa estética e psicológica da mulher, reduzindo o trauma causado pela mutilação. Atualmente, a mastectomia somente é indicada para tumores avançados, implicando na retirada da mama afetada juntamente com os linfonodos axilares.

Apesar de não ser consenso, existem estudos na literatura que apontam que mulheres que realizaram cirurgias conservadoras ou de reconstrução do seio imediatamente após a mastectomia tendem a superar mais facilmente as dificuldades com a imagem corporal, do que aquelas submetidas à extirpação completa da mama (AL-GHAZAL; FALLOWFIELD; BLAMEY, 2000; FUNG et al., 2001; McPHAIL; WILSON, 2000). 
Estes trabalhos investigam o impacto psicossocial do câncer de mama na qualidade de vida da mulher, apontando as repercussões da imagem corporal alterada nas atividades diárias de pacientes que receberam tratamento cirúrgico conservador, cirurgia de reconstrução da mama após mastectomia, ou que realizaram mastectomia como tratamento único.

Utilizando o referencial teórico-metodológico das representações sociais, o trabalho de Ferreira e Mamede (2003) teve como objetivo compreender a forma pela qual a mulher representa o seu corpo após a mastectomia, ao retornar para casa. Participaram do estudo dez mulheres submetidas a mastectomia radical ou conservadora ou quadrantectomia, por câncer de mama, entrevistadas no domicílio, no sétimo dia pós-alta, e uma vez por mês nos primeiros quatro meses subseqüentes à cirurgia.

Segundo as autoras acima, o conteúdo das entrevistas evidenciou que as mulheres, após a mastectomia representaram um corpo mutilado, experimentando sensação de impotência, dor e limitação e ainda percebiam que o mesmo necessitava de cuidados.

Os resultados do estudo apontaram que a percepção do corpo mutilado, pelas mulheres submetidas a mastectomia radical, se relacionou a sentimentos de tristeza e estranheza. Também apontaram que, durante a internação as mulheres estudadas acreditavam que a situação de dependência dos outros para se cuidarem era normal, mas que a expectativa de reassumirem seus papéis domésticos e de cuidados com a família foi frustrada pela percepção das dificuldades a serem enfrentadas, tais como a dor e limitações físicas.

Um estudo de Duarte e Andrade (2003) buscou identificar a forma pela qual seis mulheres mastectomizadas percebiam sua sexualidade. Essas mulheres apresentavam idade entre trinta e sete a cinqüenta e cinco anos e o tempo de cirurgia de um ano e meio a oito anos. Todas as mulheres tiveram diagnóstico avançado de câncer de mama e foram submetidas à mastectomia radical, sendo que três delas optaram pela cirurgia de reconstrução da mama. Como técnica de coleta de dados foram utilizadas entrevistas não dirigidas que, conforme referem os autores, buscou facilitar a livre expressão de questões relacionadas ao processo de adoecimento e as repercussões psicossociais vividas pelas pacientes após a cirurgia.

Os resultados apontaram o sentimento de estranheza e sofrimento das mulheres ao lidarem com o próprio corpo após a mastectomia, ao observarem a ausência de uma das 
mamas ou ambas e também a perda dos cabelos, decorrentes da quimioterapia. Estas mulheres mencionaram a diminuição das atividades praticadas em grupos de amigos e também alterações na qualidade da relação sexual.

Com relação aos depoimentos das mulheres que realizaram a cirurgia de reconstrução da mama, a maioria delas considerou a experiência como uma oportunidade de recuperação da feminilidade, sexualidade e erotismo. Este aspecto também é discutido no trabalho de Ferreira e Mamede (2003), onde as mulheres entrevistadas referiram-se à cirurgia plástica como uma possibilidade de recuperação do corpo imperfeito.

Fung et al. (2001) investigaram o impacto de diferentes tipos de cirurgia para câncer de mama em mulheres chinesas, especificamente a mastectomia, o tratamento cirúrgico conservador e a reconstrução imediata da mama após a mastectomia. Quarenta e nove pacientes foram entrevistadas, transcorridos seis meses da realização da cirurgia e novamente após dois anos. Do total de sujeitos entrevistados, dezessete mulheres receberam tratamento cirúrgico conservador, quinze pacientes mastectomia radical e dezessete mulheres optaram pela reconstrução da mama no período pós-operatório imediato.

A percepção da imagem corporal foi um dos aspectos avaliados no estudo, por meio de entrevistas em profundidade sendo constatado que as mulheres que receberam tratamento cirúrgico conservador e reconstrução apresentaram menos dificuldades com a imagem corporal, comparadas às que realizaram mastectomia radical. Essas pacientes mostraram menor preocupação com a aparência e com a mudança do corpo, apontando satisfação quanto ao vestir e na relação sexual com os companheiros.

Apesar dos trabalhos citados avaliarem as alterações da imagem corporal junto de outros aspectos psicossociais em mulheres que receberam diferentes modalidades de tratamento cirúrgico por câncer de mama, vale ressaltar que nem todos os estudos da literatura se reportam às alterações das atividades da mulher em decorrência destas modificações corporais. Estes estudos apontam as cirurgias conservadoras e de reconstrução da mama como responsáveis pela melhora de aspectos psicológicos das pacientes, como a redução de sintomas depressivos e a satisfação ante a imagem corporal.

A exemplo disso, Mcphail e Wilson (2000) descreveram as experiências de mulheres inglesas que receberam tratamento cirúrgico conservador por câncer de mama, diagnosticado na fase inicial. Os dados foram coletados após três meses da realização da 
cirurgia, por meio de questionários enviados a setenta e seis pacientes. Segundo os autores, os resultados evidenciaram que oitenta por cento das pacientes manifestaram satisfação com a aparência física após o tratamento.

Al-Ghazal, Fallowfield e Blamey (2000) avaliaram os efeitos psicológicos e a satisfação de pacientes com câncer de mama submetidas à cirurgia conservadora, mastectomia radical e mastectomia seguida de cirurgia de reconstrução da mama. Participaram do estudo 577 pacientes com idade inferior a setenta anos, das quais 254 receberam tratamento conservador, 202 realizaram mastectomia radical e 121 mulheres foram submetidas à reconstrução da mama após a mastectomia. Para a coleta de dados foram utilizadas escalas para se avaliar, respectivamente, (1) depressão e ansiedade e (2) imagem corporal. Foi também utilizado um questionário para a avaliação do nível de satisfação das pacientes, de acordo com as três modalidades de tratamento cirúrgico que receberam.

Os resultados da pesquisa apontaram para diferenças significativas quanto a satisfação e aos aspectos psicológicos das pacientes, de acordo com o tratamento cirúrgico a que foram submetidas. As mulheres que receberam cirurgia conservadora apresentaram melhores resultados na avaliação da imagem corporal do que as pacientes que realizaram mastectomia radical ou mesmo a cirurgia de reconstrução do seio. Para os autores, isso ocorreu pelo fato do tratamento conservador ser menos desfigurante que as outras modalidades cirúrgicas como a mastectomia e mesmo a reconstrução mamária.

Entretanto, não existe consenso na literatura quanto aos benefícios psicológicos ou para a percepção positiva da imagem corporal decorrentes das cirurgias conservadoras e da reconstrução da mama para as mulheres em tratamento por câncer mamário.

Hartcourt et al. (2003) desenvolveram um estudo objetivando investigar as implicações psicológicas decorrentes da mastectomia radical e da reconstrução imediata e tardia da mama posteriormente à mastectomia, em mulheres inglesas em idade entre vinte $\mathrm{e}$ nove e setenta e oito anos. Do total de 103 mulheres que participaram da pesquisa, cinqüenta e seis realizaram mastectomia radical, trinta e sete receberam cirurgia de reconstrução no período imediato à mastectomia e dez fizeram a reconstrução tardia.

Os dados foram obtidos por meio de entrevistas semi estruturadas, durante os períodos pré-operatório e posteriormente aos seis e doze meses da realização da cirurgia. 
Nesses mesmos períodos, também foram aplicados questionários para avaliação do estado psicológico e da imagem corporal das mulheres estudadas.

Os resultados apontaram uma diminuição do estresse psicológico no período de um ano pós-cirurgia, em todas as mulheres pesquisadas independentemente do tratamento cirúrgico realizado, o que constitui um indicativo de que os benefícios psicológicos obtidos independem do tipo de cirurgia realizada. Este aspecto foi ressaltado pela constatação de que mesmo as mulheres submetidas a mastectomia radical sem possibilidade de reconstrução da mama apresentaram melhora no estado psicológico global, enquanto outras pacientes que optaram pela reconstrução imediata ou tardia mostraram alterações na avaliação da imagem corporal.

Para Hartcourt et al. (2003) os resultados do estudo alertam aos profissionais de saúde quanto a inconsistência das afirmações de que a cirurgia de reconstrução da mama necessariamente traz benefícios psicológicos e para a imagem corporal das mulheres, comparadas às pacientes mastectomizadas.

Assim, novamente consideramos necessário atentar ao caráter de subjetividade envolvido no contexto da assistência e da avaliação de questões relativas à imagem corporal de mulheres mastectomizadas, na medida em que variáveis psicológicas, sociais, também referentes à modalidade de tratamento cirúrgico devem ser consideradas, quando se pretende o desenvolvimento de uma abordagem adequada às necessidades destas pacientes.

\subsubsection{Avaliação da imagem corporal}

A literatura sobre câncer de mama comumente apresenta avaliações sobre a imagem corporal de pacientes junto de outros aspectos, como o impacto psicossocial da doença em mulheres submetidas a mastectomia radical, comparadas à cirurgias conservadoras, de reconstrução da mama ou mesmo ao tratamento adjuvante (BREDIN, 1999; HARTCOURT; RUMSEY, 2001).

Estes estudos discorrem sobre as modificações ocorridas no corpo da mulher focalizando-se na retirada total ou parcial da mama, de acordo com os diferentes tratamentos cirúrgicos citados, mas a crescente utilização dos tratamentos adjuvantes na última década tem também influenciado na imagem corporal das mulheres. Assim, o aumento do peso e a perda dos cabelos, decorrentes da quimioterapia, são aspectos que 
necessitam ser incluídos nas avaliações da imagem corporal da mulher em tratamento para o câncer das mamas (McPHAIL; WILSON, 2000).

Acresce-se a isso que a imagem corporal está intimamente relacionada a aspectos psicológicos, especialmente a sexualidade, acarretando aos pesquisadores e profissionais da saúde dificuldades de se avaliá-la adequadamente devido a ampla gama de variáveis nela imbricadas, incluindo a fragilidade do próprio conceito (HARTCOURT; RUMSEY, 2001; SHEARSMITH, 2001).

Parte dessas dificuldades centra-se no fato de algumas pacientes negarem os problemas com o próprio corpo devido ao temor do estigma de se assumirem como doentes, ou ainda por sentirem-se constrangidas diante de questões associadas à sexualidade, visto que esta última geralmente aparece vinculada ao conceito de imagem corporal, tornando difícil sua avaliação por meio de instrumentos quantitativos (BREDIN, 1999; FUNG et al., 2001).

O tempo de ajustamento da paciente com câncer de mama à sua nova imagem corporal constitui outra variável a ser considerada para tal avaliação, pois este processo não é vivido da mesma forma e ao mesmo tempo por todas as mulheres (HARTCOURT; RUMSEY, 2001).

Embora a avaliação adequada da imagem corporal de pacientes com câncer mamário seja dificultada pelos fatores mencionados, profissionais da saúde e pesquisadores devem realizar este procedimento de forma mais efetiva junto desta clientela. Devido às variáveis altamente subjetivas envolvidas neste processo, os pesquisadores costumam elaborar seus próprios instrumentos para a avaliação da imagem corporal destas pacientes diante da conseqüente inconsistência dos instrumentos padronizados disponíveis para tal procedimento.

Os instrumentos de avaliação, elaborados pelos pesquisadores, também apresentam alta subjetividade, pois são elaborados e aplicados para casos particulares, dependendo dos objetivos de cada pesquisa, tornando inviável sua utilização em outros estudos (BREDIN, 1999; HARTCOURT; RUMSEY, 2001).

Segundo Shearsmith (2001), terapeutas ocupacionais atuantes na área de oncologia, mais especificamente com pacientes que recebem cuidados paliativos, têm utilizado instrumentos quantitativos para avaliação da imagem corporal, associada à sexualidade, o que acaba restringindo sua avaliação a esta última área. 
A avaliação da imagem corporal não pode estar limitada a áreas isoladas, tal como a sexualidade, pois tem implicações mais amplas. Alterações da imagem corporal acarretam aos pacientes outros problemas, como comprometimentos no desempenho ocupacional e psicológico, e a dimensão dessa problemática deve ser apreendida por meio da compreensão das experiências individuais dos pacientes que passaram por tais alterações (SHEARSMITH, 2001).

Shearsmith (2001) aponta que a escuta atenta ao relato das pacientes parece ser o caminho mais adequado para a identificação das questões relativas à imagem corporal, devido a alta subjetividade das questões envolvidas, as quais não podem ser satisfatoriamente avaliadas pelo uso de instrumentos quantitativos.

Nesse sentido, os profissionais da saúde devem valorizar e priorizar a autoavaliação das pacientes sobre o próprio corpo, pois constituem importantes fontes de informação (BREDIN, 1999; McPHAIL; WILSON, 2000).

Com vistas a possibilitar às mulheres com câncer mamário a expressão e o diálogo aberto das questões relacionadas às dificuldades vividas com a imagem corporal e sua interferência no desempenho ocupacional, neste estudo foram utilizadas as oficinas de reflexão como técnica de coleta de dados, sendo um instrumental desenvolvido na área da saúde da mulher.

A escolha por este instrumental foi por entendermos que a avaliação das dificuldades com a imagem corporal pós-cirurgia por câncer de mama não seria possível por meio do emprego de instrumentos quantitativos, conforme assinalado, e por considerarmos que a livre expressão das mulheres estudadas traduziria, com mais clareza, as diferentes representações sobre a problemática vivida com a imagem corporal e suas repercussões no desempenho ocupacional.

Entendemos que a mulher ainda não é vista em sua integralidade em serviços pautados no modelo estrutural e funcionalista, cuja visão biológica não adota métodos participativos que lhe possibilite ser sujeito, no que concerne à sua saúde. Dentre as diretrizes do Programa de Assistência Integral à Saúde da Mulher (PAISM), de 1983, encontram-se práticas educativas que visam assegurar a apropriação, pela clientela, dos conhecimentos necessários a um maior controle sobre a própria saúde, sendo as oficinas de reflexão uma dessas estratégias educativas (DINIZ et al., 2000). 
Diante do que foi exposto, delimitamos, a seguir, os objetivos do presente estudo, baseando-nos no pressuposto de que a alteração da imagem corporal se constitui em fator interferente à realização efetiva e adequada das atividades das mulheres operadas por câncer mamário, independentemente do tratamento cirúrgico a que foram submetidas. 


\section{OBJETIVOS}

\section{- Objetivo geral}

Identificar as relações estabelecidas pelas mulheres com câncer de mama entre o desempenho das AVDs, atividades produtivas e do trabalho, atividades de lazer e as representações sociais que fazem sobre seus corpos.

\section{- Objetivos específicos}

1) Identificar as representações sociais de mulheres com câncer de mama sobre o corpo feminino após o tratamento para o câncer de mama e suas relações com a imagem corporal de si mesmas;

2) Identificar as representações sociais da imagem corporal após tratamento do câncer de mama e suas relações com as AVDs;

3) Identificar as representações sociais da imagem corporal após tratamento do câncer de mama e suas relações com as atividades produtivas e do trabalho;

4) Identificar as representações sociais da imagem corporal após tratamento do câncer de mama e suas relações com as atividades de lazer. 


\section{REFERENCIAL TEÓRICO}

A escolha pela Teoria das Representações Sociais (TRS), na perspectiva das Ciências Sociais, como referencial teórico para a análise das questões vividas pelas mulheres que realizaram cirurgia por câncer de mama foi por entendermos que a percepção sobre o retorno ao desempenho das atividades as fazem identificar mais claramente as alterações da imagem corporal impostas pelo tratamento da doença.

Situação esta que interfere em diferentes dimensões como o repensar as condições do próprio corpo após o tratamento, em uma perspectiva individual e frente às pessoas com quem convivem durante o fazer, como o lidar com sentimentos a partir da representação de um corpo diferente do ideal valorizado socialmente e a busca por estratégias para dar continuidade às demandas das atividades.

Assim, a Teoria das Representações Sociais foi aqui utilizada para tornar visível estas questões que, como as compreendemos, puderam ser representadas de diferentes formas pelas mulheres estudadas.

\subsection{Fundamentos teóricos da Teoria das Representações Sociais}

As representações sociais consistem em um termo filosófico que significa a reprodução de uma percepção retida na lembrança ou do conteúdo do pensamento. Na internalidade das Ciências Sociais, as representações sociais são definidas como categorias de pensamento que expressam a realidade, podendo explicá-la, justificá-la ou, ainda, questioná-la. Tais percepções, enquanto material de estudo, são consensualmente importantes, atravessando a história e as diferentes correntes de pensamento sobre o social (MINAYO, 1995).

O termo representações sociais designa um campo de estudo elaborado pelo psicólogo social francês Serge Moscovici a partir de sua obra "La psychanalyse, son image, son public", de 1961, considerada marco inicial representativo da teoria homônima. Nessa obra, Moscovici ocupa-se em apreender a representação social da psicanálise pela população parisiense no fim dos anos 1950. Época em que aumenta o interesse pelos fenômenos do domínio do simbólico e uma preocupação para explicá-los através das noções de consciência e imaginário (ARRUDA; 2002; SÁ, 1995). 
Sabe-se que a teoria das representações sociais foi elaborada a partir da crítica de Moscovici à perspectiva individualista da psicologia social de tradição norte-americana. Sendo ele atuante na vertente psicossociológica renovadora de origem européia, seu argumento crítico centra-se no questionamento daquela perspectiva focalizar processos psicológicos individuais, influenciados por um social vago e abstrato, portanto, incapaz de dar conta da dimensão cotidiana das relações sociais, da vida humana, em nível mais individual ou coletivo.

Moscovici buscou, inicialmente, fundamentar sua crítica à psicologia social em uma tradição sociológica tão oposta como a de Durkheim, que se posicionava contrariamente diante de qualquer possibilidade de explicação psicológica dos fatos sociais (SÁ, 1995).

Nóbrega (1990) refere que Durkheim, ao buscar compreender o aspecto essencial e permanente da humanidade, tomou como objeto de estudo as práticas religiosas das tribos das sociedades primitivas australianas, concebendo a natureza fundamental do homem como residindo na religião. Atribuiu a esta prática social a propriedade de representar, coletivamente, os fenômenos capazes de assegurar os laços entre os membros de uma sociedade e de os manter por gerações.

Durkheim desenvolveu o conceito de representações coletivas propondo um conjunto sistemático de elementos para explicar uma multiplicidade de fenômenos sociais. Esses elementos compreendiam saberes e práticas partilhadas coletivamente, tais como crenças, mitos, ciência, religiões e opiniões, com a característica de revelar o que havia de irredutível à experiência individual e que se estende no tempo e no espaço (NÓBREGA, 1990).

As representações coletivas, ao serem compartilhadas por um grupo social, estabelecem formas de representar o mundo e as relações sociais, assegurando a coesão social. Estas representações se impõem coercitivamente à coletividade, assemelhando-se ao poder de uma autoridade social (TURA, 2004).

Assim, Moscovici não construiu sua obra em um vazio cultural. Apoiou-se nos fundadores das ciências sociais na França, principalmente em Durkheim, um dos expoentes da sociologia moderna (FARR, 1995).

Observa-se que Durkheim propôs o termo representações coletivas para enfatizar a primazia do pensamento social em relação ao pensamento individual, considerando 
fenômenos como os mitos, a religião, a ciência, as categorias de espaço e tempo como conhecimentos inerentes à sociedade (HERZLICH, 1991; SÁ, 1995).

Em sua obra "As regras do método sociológico", Durkheim concebe a sociedade como uma realidade exterior aos indivíduos, considerando que as formas coletivas de se pensar ou agir, enquanto parte dessa realidade externa, impõem-se aos sujeitos que, em cada momento, conformam-se com elas (DURKHEIM, 2002).

Durkheim (2002) concebe essas formas coletivas como coisas que têm existência própria, sublinhando que os indivíduos não têm como reagir contra elas, sendo, ao contrário, influenciados por elas.

A noção de fato social figura em um conceito norteador para o entendimento sobre as regras do método sociológico: "O fato social não pode definir-se pela sua generalidade no interior da sociedade. Características do fato social: $1^{\circ}$ - a sua exterioridade em relação às consciências individuais; $2^{\circ}$ - a ação coerciva que exerce ou é suscetível de exercer sobre as mesmas consciências [...]" (DURKHEIM, 2002, p. 31).

Nesse sentido, os fatos sociais são externos à consciência e se estruturam na interação entre os indivíduos, havendo um sentimento e uma consciência coletiva preexistentes. As diferentes formas de pensar e agir são construtos coletivos e, nessa ótica, não derivam de indivíduos isolados (TURA, 2004).

Partindo da afirmação de Durkheim (2002) de que os fatos sociais estão presentes onde há organização social definida, torna-se possível compreendê-los enquanto objeto de estudo da sociologia diferenciando-os, desse modo, dos fatos sociais tomados como objeto de estudo de outras áreas do conhecimento. Pois, ao priorizar a sociedade como lócus da vida do indivíduo, entende que o modo coletivo de viver interfere no individual.

Ao publicar sua obra sobre a representação social da psicanálise, Moscovici deu vida nova a essa noção, remodelando o conceito durkheimniano e, nesse sentido, preenchendo a lacuna existente entre a Psicologia Social e a Sociologia que buscavam, respectiva e isoladamente, explicar fenômenos coletivos humanos em uma perspectiva individual, no caso da primeira, e coletiva, como almejava a segunda (ARRUDA, 2002; HERZLICH, 1991; NÓBREGA, 1990). 
Também lhe deu novas conotações e atualidade uma vez que passou a servir à análise de uma sociedade mais complexa do que a sociedade francesa onde viveu Durkheim (TURA, 2004).

\subsubsection{A Teoria das Representações Sociais}

Moscovici resiste a apresentar uma definição clara sobre as representações sociais, acreditando que isso implicaria em comprometer a amplitude conceitual da teoria. Esta falta de delimitação teórico - conceitual fez com que o termo representação social se fizesse presente em diferentes áreas do conhecimento, dificultando ainda mais a elaboração de uma definição comum (SÁ, 1995).

Embora criticado quanto a fluidez conceitual das representações sociais, com sua diversidade de enunciados, Moscovici posiciona-se afirmando tratar-se de uma fluidez proposital, na medida em que possibilita desenvolver a teoria e a criatividade dos pesquisadores centrando-se na descoberta e não na verificação e na comprovação (ARRUDA, 2002).

Abric (1998) reafirma a gênese da teoria das representações sociais pelo abandono da distinção clássica, particularmente desenvolvida pelas abordagens comportamentalistas, entre sujeito e objeto. Este autor apoia-se em Moscovici para argumentar que inexiste a separação entre o universo interno e externo do indivíduo ou de um grupo, pois sujeito e objeto não são forçosamente distintos. Considera ainda que não existe uma realidade objetiva a priori, mas que ela é representada pelo indivíduo ou pelo grupo, sendo reconstruída no seu sistema cognitivo e integrada no seu sistema de valores, dependendo da história e dos contextos social e ideológico que cercam o indivíduo.

As representações sociais são socialmente elaboradas e compartilhadas contribuindo para a construção de uma realidade comum possibilitando a comunicação. Tais fenômenos, acessados a partir de seu conteúdo cognitivo devem ser entendidos na internalidade do seu contexto de produção (SPINK, 1993).

Nesse sentido, torna-se "[...] necessário entender, sempre, como o pensamento individual se enraíza no social (remetendo, portanto, às condições de sua produção) e como um e outro se modificam mutuamente [...]" (SPINK, 1995, p.89). 
Moscovici, ao referir-se à noção de representações sociais a compreende como uma forma equivalente, na sociedade atual, aos mitos e crenças das sociedades tradicionais, caracterizando um conjunto de conceitos, explicações e afirmações geradas na vida cotidiana e a partir das comunicações interpessoais, sendo consideradas como a versão contemporânea do senso comum (LEME, 1995).

A proposição moscoviciana sobre a noção de representações sociais a define como sendo uma construção social de um saber ordinário, de senso comum, elaborado a partir das interações sociais através das crenças, valores e estereótipos partilhados por um grupo social originando uma visão comum dos diferentes objetos, tais como pessoas, acontecimentos, categorias etc. Essa definição, ao incorporar teorias acerca dos saberes populares são construídas e partilhadas coletivamente, com o objetivo de elaborar e interpretar o real (ANADON; MACHADO, 2001; OLIVEIRA; WERBA, 2001).

Nesse sentido, as representações sociais, enquanto imagens construídas sobre o real, são um material importante para a pesquisa no interior das Ciências Sociais (MINAYO, 1995).

Observamos que, de acordo com os autores citados anteriormente, a linguagem é um elemento primordial e constitutivo da comunicação interpessoal, sendo considerada como geradora e principal meio de expressão das representações sociais.

As representações sociais manifestam-se por meio de palavras, sentimentos e condutas que se institucionalizam, devendo ser compreendidas a partir das estruturas e dos comportamentos sociais. A linguagem é tomada como forma de conhecimento e de interação social, embora seja passível de traduzir um pensamento fragmentário limitandose a aspectos parciais da experiência existencial, sendo, tal experiência, freqüentemente contraditória (MINAYO, 1995).

A realidade vivida é também representada e através dela, os atores sociais se movem e edificam sua vida explicando-a mediante seu estoque de conhecimentos. Assim, a visão de mundo dos diferentes grupos expressa as contradições e conflitos presentes nas condições em que foram engendradas, sendo importante um olhar crítico às representações sociais, visto corresponderem a situações reais de vida.

O senso comum passa a ser, nesse sentido, um sistema de representação social empírico e observável, capaz de revelar a natureza contraditória da organização em que os atores sociais estão inseridos. Esse processo de revelar se faz pela comunicação gerada na 
vida cotidiana, em que as palavras traduzem os fios ideológicos da sociedade, sendo a compreensão da fala imprescindível à compreensão das relações sociais que ela expressa (MINAYO, 1995).

\subsubsection{As representações sociais e suas funções}

A comunicação social é lócus de produção das representações sociais, que se estruturam em três níveis: 1) cognitivo (refere-se ao acesso desigual das informações, interesse ou implicação dos sujeitos, necessidade de agir em relação aos outros); 2) elaboração das representações sociais (objetivação e ancoragem); 3) edificação das condutas (opiniões, atitudes, estereótipos) (NÓBREGA, 1990).

As representações sociais respondem a quatro funções: a primeira função é permitir aos atores sociais compreender e explicar a sua realidade, a partir da inserção de conhecimentos adquiridos em um quadro assimilável e compreensível por eles próprios, em consonância com seu funcionamento cognitivo e valores compartilhados. Auxiliando-os, desse modo, a se organizar e dominar seu ambiente material e social.

A segunda função atua na direção de facilitar a comunicação possibilitando as trocas sociais, a partir deste quadro de referência comum. Esta comunicação estabelecida entre os membros de um grupo atua no sentido de nominar e classificar partes do mundo desse grupo, também de experiências vividas no âmbito individual e coletivo dessa comunidade.

A função identitária, outra função das representações sociais, atua de forma a garantir a especificidade e imagem positiva do grupo, situando indivíduos e grupos em um contexto social possibilitando-lhes a elaboração de uma identidade individual e social.

Por fim, a função justificadora possibilita aos atores sociais explicar e manter suas condutas em determinadas situações, diante de seus parceiros e nas relações entre grupos (ABRIC, 1998; MOSCOVICI, 1978; NÓBREGA, 1990).

\subsubsection{Formação das Representações Sociais}


As representações sociais se estruturam mediante dois processos, denominados objetivação e ancoragem. Estes processos se desenvolvem a partir do posicionamento de cada sujeito diante de um acontecimento e de suas observações acumuladas desde então (MOSCOVICI, 1978; NÓBREGA, 2001).

A objetivação refere-se ao processo de materialização das abstrações, no sentido de tornar concreto o que antes era impalpável ou simbólico, reabsorvendo “[...] um excesso de significações materializando-as (e adotando assim certa distância a seu respeito). É também transplantar para o nível de observação o que era apenas inferência ou símbolo[...] Houve substituição do percebido pelo conhecido" (MOSCOVICI, 1978, p. 111).

O processo de objetivação desenvolve-se em três etapas, sendo elas a construção seletiva, caracterizada pela seleção de informações circulantes no meio objetivo; o esquema figurativo, etapa em que se dá o transporte dos elementos do meio objetivo ao cognitivo, condensando-os e atenuando-os de seus aspectos conflitivos para que sejam inseridos em uma ordem preexistente, sem desestabilizar os pensamentos anteriormente estruturados; a esta etapa segue-se a naturalização, em que os elementos internalizados se tornam evidentes e simples, possibilitando ao sujeito julgá-los como uma realidade quase concreta (MOSCOVICI, 1978).

A ancoragem consiste no processo de assimilação e inserção de idéias e pensamentos inéditos aos pensamentos sociais preexistentes. Articula-se dialeticamente com a objetivação, garantindo três funções essenciais da representação, sendo estas a incorporação do novo, a interpretação do real e a orientação dos comportamentos (NÓBREGA, 1990; SPINK, 1993).

As representações sociais difundem-se através de três modalidades de comunicação social, denominadas difusão, que corresponde à edificação das condutas de opiniões; a propagação, correspondente às atitudes; e a propaganda, associada aos estereótipos (MOSCOVICI, 1978).

Nóbrega (2001) explicita os elementos indutores da comunicação, acima citados.

1) Difusão à opinião: Esta modalidade de comunicação social caracteriza-se pela indiferenciação de posições assumidas entre o emissor e o receptor da mensagem, 
sendo tal noção associada à opinião. Reflete-se em uma descontinuidade e contradição dos temas levando a uma fragilidade e fluidez das posições adotadas pelos atores.

2) Propagação à atitude: implica que as mensagens passem por um processo de organização psíquica, traduzindo-se em uma atitude, aqui entendida como uma relação maior ou menor do sujeito para com o objeto, produzindo um efeito seletivo sobre as reações dos sujeitos.

3) Propaganda ao estereótipo: gerada a partir de relações sociais conflituosas, esta forma de comunicação atua na elaboração de uma postura relativa ao objeto. Exige unidade e auto-afirmação de um grupo em relação a outro grupo, sendo a representação do objeto conflitivo efetivada em um referencial de verdadeiro ou falso, forjando estereótipos, provocando respostas genéricas, rígidas e simplificadoras dos fatos.

No tocante aos processos de elaboração das representações sociais aqui apresentados, Nóbrega (1990) sugere um esquema para facilitar a visualização desses processos, da seguinte forma: 1) cognitivo; 2) elaboração das representações sociais: objetivação e ancoragem; 3) edificação das condutas: opiniões (difusão), atitudes (propagação) e estereótipos (propaganda).

A aplicabilidade da teoria das representações sociais na área da saúde é expressiva, possibilitando análises referentes às políticas sociais e também ao planejamento de intervenções de âmbito social. Pesquisadores da área da saúde têm encontrado neste domínio epistemológico uma importante base teórico-metodológica para suas questões de pesquisa e objetos de estudo. A produção brasileira no campo das representações sociais entre os anos de 1988 e 1997 reuniu aproximadamente 867 títulos sendo $28 \%$ desses trabalhos referentes a estudos da área da saúde (TURA; MOREIRA, 2004).

As representações sociais podem ser tratadas como produto e como processo, sendo que cada enfoque determina a escolha do método e do modo de compreensão de um fenômeno. Enquanto produto, as representações sociais emergem como um pensamento constituído e um campo estruturado e, nessa perspectiva, a pesquisa busca depreender os elementos constitutivos das representações, que devem ser analisadas tomando como base as condições em que foram produzidas (SPINK, 1995).

Os estudos que tratam das representações sociais enquanto processo postulam que as mesmas emergem como pensamento constituinte ou núcleos estruturantes, 
voltando-se para a compreensão da elaboração e transformação das representações sob a força das determinações sociais, ou ainda à compreensão do funcionamento e eficácia das representações na interação social. Estes estudos visam examinar os processos de objetivação e ancoragem na elaboração cognitiva ou, por outro lado, a formulação de hipóteses sobre os núcleos centrais das cognições de uma representação (SPINK, 1995).

No presente estudo, nossa opção pelo desenvolvimento de uma abordagem qualitativa tornou possível a compreensão das representações sociais de mulheres que realizaram cirurgia por câncer de mama. Especificamente, das dificuldades decorrentes da cirurgia no que tange à imagem corporal e sua interferência nas atividades diárias, sendo, tais representações, aqui tratadas enquanto produto, pois a partir das representações obtidas foi possível atingir as condições sociais que geraram às mulheres estudadas diferentes percepções, sentimentos e atitudes diante da problemática vivida. 


\section{PERCURSO DO MÉTODO}

\subsection{Tipo de estudo}

O presente estudo se caracteriza por uma pesquisa qualitativa por ter possibilitado compreender melhor o significado de um corpo alterado pela cirurgia por câncer de mama e suas repercussões nas atividades de mulheres submetidas ao tratamento da doença e por ter possibilitado apreender as crenças, valores e atitudes atribuídos ao fazer pelas mulheres estudadas.

Nossa opção pela pesquisa qualitativa deu-se a partir do entendimento de que este tipo de abordagem se focaliza em um recorte da realidade impossível de ser quantificada, pois ao se centrar no universo de significados, motivações, crenças, valores e atitudes, neste caso referente às questões vividas pelas mulheres com câncer de mama, tal abordagem corresponde a um espaço mais profundo das relações, dos processos e dos fenômenos que não podem ser reduzidos à operacionalização de variáveis (MINAYO, 2001).

Nesse sentido, a abordagem qualitativa se mostrou pertinente por possibilitar o aprofundamento do fenômeno pesquisado considerando a complexidade do comportamento humano e a impossibilidade de ser descrito e compreendido unicamente por meio de suas características exteriores, pois o mesmo depende também de atitudes mentais e do sentido que os agentes atribuem às suas ações, ou seja, sua subjetividade (GOLDENBERG, 1997).

Assim, considerando as características de subjetividade envolvidas nos processos de avaliação da imagem corporal de mulheres com câncer mamário, justificase a abordagem qualitativa adotada nesta pesquisa na medida em que esta nos possibilitou lançar um olhar mais profundo para a realidade destas mulheres, cujas experiências e representações seriam dificilmente medidas quantitativamente.

A pesquisa qualitativa apresenta características básicas as quais, de acordo com Bogdan e Biklen (1994), são:

1- Os dados devem ser coletados onde ocorre o fenômeno pesquisado sendo o pesquisador o instrumento principal visto ser ele quem analisará os dados;

Essa característica foi levada em consideração quando da escolha do local deste estudo, ou seja, o Núcleo de Ensino, Pesquisa e Assistência de Mastectomizadas 
(REMA), de onde emergiram as questões trazidas por elas sobre as dificuldades vividas com as alterações da imagem do corpo e em suas atividades, após tratamento por câncer de mama.

2- Os dados coletados são predominantemente descritivos, possibilitando aprofundamento no estudo;

Neste estudo foi utilizado como técnica de coleta de dados a oficina de reflexão, com vistas a depreender e valorizar o significado das representações elaboradas pelas mulheres estudadas. A oficina de reflexão consiste em instrumento de investigação concebido na área da saúde da mulher, sendo também um recurso terapêutico grupal, possibilitador do resgate do papel das mulheres enquanto sujeitos das diferentes experiências vividas por elas, em diversos contextos.

3- $O$ pesquisador tem em conta o processo da investigação e não o seu produto;

As relações interpessoais estabelecidas entre as mulheres, sujeitos deste estudo, por meio de encontros grupais, foram singulares para a emergência de diferentes representações a cada encontro, processo este que tornou possível identificar a diversidade de sentidos atribuídos à situação vivida pelas mulheres com câncer de mama com relação ao corpo mutilado e as repercussões em seu fazer.

4- Os dados são analisados de forma indutiva;

Este estudo, adotando como referencial teórico a Teoria das Representações Sociais (TRS), foi orientado por um quadro teórico que norteou a coleta e análise dos dados.

5- $\mathrm{O}$ foco da pesquisa qualitativa se centra no significado dado pelas pessoas às suas questões de vida, levando o pesquisador a valorizar a perspectiva particular dos sujeitos pesquisados.

Aqui, as experiências vividas pelas mulheres estudadas representadas em seus discursos, foram valorizadas enquanto importante recurso para se apreender o significado destas mesmas experiências. 


\subsection{Cenário do estudo}

Este estudo foi realizado no Núcleo de Ensino, Pesquisa e Assistência na Reabilitação de Mastectomizadas (REMA), vinculado ao Departamento de Enfermagem Materno Infantil e Saúde Pública da Escola de Enfermagem de Ribeirão Preto, da Universidade de São Paulo-USP.

A seleção desse serviço de reabilitação de mulheres com câncer de mama, cenário deste estudo, se mostrou adequada à proposta de identificar as mudanças ocorridas nas atividades de mulheres submetidas à cirurgia, a partir das alterações da imagem corporal pós-tratamento.

A escolha pelo REMA baseou-se em dois motivos: primeiro, por atender a um grande número de usuárias, o que possibilitou o contato com mulheres de diferentes contextos sócio-culturais, facilitando a estruturação de um grupo heterogêneo que compôs a amostra desta pesquisa, permitindo uma análise dos problemas expressos sob diferentes perspectivas de vida, e por ter possibilitado uma intervenção esclarecedora, empática e direcionada às necessidades dessas mulheres, na tentativa de suprir a carência de informações sobre os cuidados com o corpo e para com a realização de suas atividades.

O REMA foi estruturado no ano de 1989 nas dependências da Escola de Enfermagem de Ribeirão Preto da Universidade de São Paulo, visando assistir a mulheres com câncer de mama em uma perspectiva multidimensional que incluísse as necessidades anatômicas e fisiológica destas mulheres e também aquelas de ordem psicológica, emocional e social para, com isso, se buscar sua assistência integral.

Acresce-se, a este objetivo, um olhar voltado para a abordagem das questões vividas pelas mulheres e por suas famílias a partir do diagnóstico do câncer mamário e ainda a busca pelo desenvolvimento de seus papéis e habilidades que, como referido, tendem a sofrer alterações diante do diagnóstico e tratamento da doença (MAMEDE, 1991).

A criação do serviço partiu da iniciativa de um grupo de docentes da Escola de Enfermagem de Ribeirão Preto-USP, sendo sua coordenação atualmente efetivada por uma docente deste grupo. O REMA atende a mulheres com câncer de mama às segundas, quartas e sextas-feiras no horário de 8:00 às 12:00 horas, sendo a demanda encaminhada pelos serviços de saúde da cidade e região, ou mesmo por meio da 
divulgação efetivada pelas próprias mulheres assistidas no serviço (ALMEIDA, 1997; CLAPIS, 1996; MAMEDE, 1991).

Para a consolidação de sua proposta de ensino, pesquisa e assistência, o serviço conta com uma equipe composta por docentes da Escola de Enfermagem de Ribeirão Preto-USP, assim como enfermeiras assistenciais, fisioterapeutas, psicólogos, alunos de graduação e pós-graduação em nível de mestrado e de doutorado.

Além disso, o REMA serve como campo de estágio para alunos de graduação e pós-graduação em enfermagem e de treinamento de profissionais enfermeiros, fisioterapeutas, terapeutas ocupacionais e psicólogos. Até o momento de elaboração deste estudo, participavam da equipe multidisciplinar profissionais de enfermagem, fisioterapia, terapia ocupacional, psicologia e educação física (USP, 2006).

\subsection{Sujeitos do estudo}

Os sujeitos deste estudo foram oito mulheres, em atendimento no REMA, que realizaram cirurgia por câncer de mama transcorridos quatro a doze meses da realização da mesma. Esse período foi proposto por ser a fase em que as mulheres vivenciam seu retorno à vida de atividades de modo mais efetivo, passado o momento das inquietações do pós-alta imediato.

Essa opção levou em consideração a literatura científica, ao apontar que no período do pós-alta imediato, as mulheres tendem a se preocupar com a sobrevivência, sendo as questões com a imagem corporal e o desempenho ocupacional posteriormente vivenciadas pelas pacientes, comumente no retorno a suas atividades produtivas, no lar e no trabalho (DUARTE; ANDRADE, 2003).

O número de sujeitos selecionado para este estudo foi composto por oito mulheres que aceitaram participar das oficinas e que atendiam aos critérios de estar no período entre quatro e doze meses do diagnóstico do câncer de mama e não estar em nenhuma etapa do tratamento da doença, ou seja, não realizando quimioterapia e radioterapia.

A faixa etária das oito mulheres estudadas situou-se entre 37 e 69 anos, sendo que três delas eram do lar e cinco desenvolviam atividades profissionais anteriormente à cirurgia. As ocupações profissionais exercidas por essas cinco mulheres foram as 
seguintes: funcionária doméstica; costureira; proprietária de bar; auxiliar de enfermagem e cozinheira (APÊNDICE A).

As mulheres estudadas submeteram-se a diferentes modalidades cirúrgicas, como quadrantectomia acompanhada ou não de cirurgia plástica para redução do volume da mama contralateral, mastectomia unilateral e bilateral, sendo esta última seguida de cirurgia imediata de reconstrução das mamas e nodulectomia, sendo realizada linfadenectomia axilar em todas as mulheres. $\mathrm{O}$ tipo de cirurgia variou, mas como foi realizada a linfadenectomia axilar em todas as mulheres, os cuidados com o braço homolateral à cirurgia passam a ser algo comum a todas.

Como assinalado neste estudo, a opção por mulheres submetidas a diferentes tipos de cirurgia toma por base a literatura científica, ao apontar que essas pacientes costumam experimentar dificuldades com a imagem corporal independentemente do procedimento cirúrgico realizado para a extirpação do tumor.

\subsection{Inserção do pesquisador no campo de estudo}

Conforme assinalado na parte inicial deste estudo, o vínculo e o compromisso com as pacientes assistidas no REMA vêm sendo construídos desde o ano de 1997, tendo sido fundamental para o contato prévio com as mulheres aqui estudadas.

A essa fase do estudo científico, denomina-se período exploratório, em que se dá a imersão do pesquisador no contexto estudado, dando-lhe visibilidade do problema de pesquisa contribuindo também para focalização das questões de estudo e identificação de informantes que, neste caso, foram mulheres assistidas no REMA (ALVES-MAZZOTTI, 2001).

As mulheres, sujeitos do estudo, foram por nós convidadas a participar da pesquisa a partir do mês de outubro de 2005 , tendo sido contatadas inicialmente no REMA. Nesse período, as esclarecemos quanto aos objetivos deste estudo lhes informando a não obrigatoriedade da participação, assim como:

- As técnicas de coleta de dados que foram aqui utilizadas e a necessidade de registro de nossos encontros através de filmagem; o instrumento de coleta de dados empregado neste estudo foi a oficina de reflexão, sendo as mulheres informadas sobre a necessidade de cinco encontros grupais: um primeiro encontro para explicação 
detalhada sobre a natureza da pesquisa e o tipo de participação requerida, assim como para a assinatura do termo de consentimento livre e esclarecido (APÊNDICE B); mais quatro encontros, sendo que cada um deles versaria sobre um tema específico, em consonância com os objetivos desta pesquisa;

- Foi colocada a necessidade e importância da presença de um auxiliar de coordenação dos encontros, sendo este um profissional de Psicologia, também aluno de pós-graduação do Programa de Doutorado em Enfermagem em Saúde Pública e integrante da equipe multidisciplinar do REMA. A opção por esse profissional foi importante para não causar estranheza nas pacientes, o que poderia ter ocorrido caso tivesse sido convidado um profissional desconhecido pelas mulheres em estudo;

- Posteriormente a essas explicações preliminares acerca da pesquisa, o convite às mulheres sobre a participação foi reforçado sendo que, após o aceite verbal, registramos o endereço e telefone das participantes para agendar os encontros grupais que se seguiriam;

- Na primeira quinzena do mês de novembro de 2005, após termos selecionado um laboratório da Escola de Enfermagem em que foram realizados os encontros do grupo, telefonamos às participantes informando-lhes o dia da primeira reunião e também a data, local, horário e o tempo aproximado de duração de cada um dos quatro encontros, especificamente planejados para a coleta de dados. Houve receptividade, disponibilidade e interesse das mulheres convidadas em participar desta pesquisa.

\subsection{Instrumentos}

Para a obtenção dos dados, foram utilizadas as oficinas de reflexão, consideradas, simultaneamente, um recurso terapêutico e um instrumento pertinente para as investigações desenvolvidas na área de saúde da mulher.

Sua gênese se deu no movimento feminista da década de 1970, com vistas a proporcionar um espaço alternativo para a aprendizagem, análise e ações políticas sobre a condição feminina. Estas abordagens grupais também buscavam proceder a questionamentos acerca da autoridade médica, das relações de gênero, assim como sobre a sexualidade e o corpo feminino enquanto dispositivo de controle social (CARNEIRO; AGOSTINI, 1994; CHIESA, 1996). 
A utilização desse instrumental para a coleta de dados deste estudo se deu por considerarmos duas de suas características: 1) essa técnica, tendo sido originada no movimento feminista, é pertinente para se trabalhar com mulheres visando resgatar seu protagonismo nas diferentes situações vividas; 2) apresenta proximidade com a Teoria das Representações Sociais, pois segundo Carneiro e Agostini (1994), possibilita às participantes da oficina representarem seus pensamentos, idéias, valores e sentimentos de suas vivências como mulheres no que concerne às suas atividades que, neste estudo, foram consideradas na ótica da Terapia Ocupacional: atividades da vida diária, produtivas e de lazer.

Essas oficinas podem ser coordenadas por diferentes profissionais da saúde que incorporam abordagens educativas em suas práticas. A incorporação de técnicas advindas das terapias corporais da área da saúde mental, junto ao trabalho de reflexão proposto nas oficinas fazem das mesmas um espaço singular para a consolidação de uma visão integradora do ser humano, superando a dicotomia do pensar, julgar e do agir, pois " [...] tais oficinas representam espaço inigualável para que a mulher possa se encontrar com seu próprio corpo - suporte, registro e esteio de sua vida e de sua identidade - utilizando-se essa pedagogia que inclui os momentos do sentir, do saber e do atuar" (CARNEIRO; AGOSTINI, 1994, p.57).

A abordagem das oficinas de reflexão fundamenta-se na concepção filosófica, política e metodológica da educação de Paulo Freire, na medida em que propõe a modificação da realidade opressiva e de exploração vivida, pela transformação dos objetos em sujeitos. O conceito de autonomia por ele proposto embasa esta proposta de trabalho, quando tais grupos se propõem a oferecer condições para que as mulheres possam se descobrir e se conquistar como sujeitos de sua história e de sua fala (CARNEIRO; AGOSTINI, 1994).

É a partir do diálogo sobre sua história de vida que a mulher busca a si mesma, comunicando-se e aprendendo com o outro, dando sentido novo à experiência vivida através da reflexão. Nessa perspectiva metodológica, o estar em grupo favorece a troca de experiências, auxiliando a mulher na superação do sentimento de que ela é única a passar por situações problemáticas, de forma isolada (CARNEIRO; AGOSTINI, 1994; CHIESA, 1996).

Chiesa (1996), baseando-se em Freire (1996), aponta que a principal vantagem das oficinas é o estabelecimento de uma relação horizontal entre técnicos e a 
população, visto que o espaço de discussão objetiva resgatar os conhecimentos existentes, manifestar os sentimentos relativos à vivência, facilitar a expressão e a comunicação intragrupal, aliadas à motivação para a discussão dos conteúdos.

A operacionalização das oficinas de reflexão seguem etapas pré-estabelecidas, tais como: 1) o aquecimento; 2) a proposição do tema a ser explorado; 3) a utilização de técnicas facilitadoras; 4) o compartilhamento das experiências e 5) a análise do material surgido (CARNEIRO; AGOSTINI, 1994).

Cabe ao coordenador da oficina possibilitar a articulação entre as vivências individuais dos participantes com o geral, sendo este concebido como o resultante da inserção social dos mesmos. Esta articulação entre o particular e o geral, entre a subjetividade e a objetividade constitui uma das principais funções do coordenador destes grupos (CHIESA, 1996).

A fase inicial de aquecimento auxilia no estabelecimento de um vínculo de confiança entre os componentes do grupo com o coordenador, por meio de técnicas e exercícios para estimular a interação interpessoal preparando os participantes para a reflexão que será proposta.

Embora as oficinas trabalhem com temáticas pré-determinadas, após o aquecimento segue-se a proposição e o reforço do tema do encontro pelos coordenadores. Nesta etapa, diversas técnicas mobilizadoras podem ser incorporadas para facilitar a expressão das histórias de vida das participantes do grupo, tais como colagens, dramatizações, exercícios corporais, modelagens e desenhos.

A fase do compartilhamento das experiências, também denominada processo de trocas, é vital no trabalho com oficinas de reflexão. É nela que os participantes comunicam algo de si e escuta a fala dos outros, construindo informações, experimentando a solidariedade e ainda um estado nascente de formação do sujeito coletivo, de modo a compartilhar o que antes era vivido solitariamente. O processo também possibilita a compreensão da dimensão política das situações cotidianas construídas na relação com o outro (CARNEIRO; AGOSTINI, 1994; CHIESA, 1996).

Após o compartilhamento, segue-se a fase de processamento ou análise das vivências, na qual se pode elucidar conceitos e informações de relevância para o grupo, referentes ao tema proposto e desenvolvido na oficina. Consiste em resgatar as 
vivências relatadas no grupo contextualizando-as com os diferentes processos de vida dos participantes em suas dimensões histórica, social, cultural e política.

Este processo de análise implica em uma avaliação do que foi produzido na oficina, assinalando os "[...] atores sociais, as instituições e os poderes que incidem sobre o corpo produtivo feminino, o corpo como lugar de ação e de registro da cultura" (CARNEIRO; AGOSTINI, 1994, p. 62).

\subsection{Coleta de dados e aspectos éticos}

Os dados foram coletados durante o desenvolvimento de quatro oficinas de reflexão, realizadas entre os meses de novembro e dezembro de 2005, em um laboratório adjunto ao REMA, visando assegurar ao grupo de mulheres privacidade e segurança para a expressão de suas experiências vividas. Cada oficina, realizada uma vez por semana, teve uma duração aproximada de uma hora e meia, totalizando quase seis horas de trabalho.

O tempo de duração dos encontros foi justificado por nossa preocupação em não prejudicar a concentração das participantes do grupo e por considerarmos que o horário estipulado seria suficiente para o desenvolvimento de todas as etapas de funcionamento previstas para as oficinas.

Levando em conta os aspectos éticos de pesquisa com seres humanos, conforme a resolução 196 de outubro de 1996 do Conselho Nacional de Saúde (BRASIL, 2006), reforçamos às mulheres a necessidade de filmagem dos encontros e solicitamos, após seu aceite verbal, para que assinassem o termo de consentimento livre e esclarecido posteriormente a essas explicações (APÊNDICE B).

O projeto foi avaliado pelo Comitê de ética em Pesquisa da Escola de Enfermagem de Ribeirão Preto da Universidade de São Paulo, tendo recebido parecer favorável pelo mesmo (ANEXO A).

Frente à opção de se analisar os discursos dos encontros considerando os temas surgidos em cada uma das quatro oficinas, sem destacar as participantes individualmente, isso por si garantiu o anonimato de cada uma. Neste estudo, cada grupo foi designado por: G1, G2, G3 e G4, respectivamente. 
As oficinas foram filmadas integralmente, tendo sido planejadas para a abordagem dos seguintes temas:

Tema 1 ( $1^{\mathrm{a}}$ encontro): Corpo e cirurgia: como me vejo depois da cirurgia?

Tema 2 ( $2^{\mathrm{a}}$ encontro): Corpo e atividades da vida diária (AVD);

Tema 3 ( $3^{\mathrm{a}}$ encontro): Corpo e trabalho;

Tema 4 ( $4^{\mathrm{a}}$ encontro): Corpo e lazer.

Para alcançar os objetivos deste estudo, desenvolvemos a temática acima buscando oferecer às mulheres estudadas um espaço estruturado para a percepção e apropriação de si e das outras, oportunizados pelos encontros grupais, descritos a seguir.

\subsection{Descrição das oficinas de reflexão com as mulheres estudadas}

A descrição das oficinas de reflexão que se segue visa ilustrar sua estrutura geral, assinalando o modo pelo qual os temas foram desenvolvidos em cada encontro, assim como as técnicas utilizadas para este propósito, de acordo com as fases de operacionalização de cada oficina, sendo estas, o aquecimento, o desenvolvimento do tema e a síntese final.

As oficinas de reflexão foram realizadas em um laboratório adjunto ao REMA, dentro da Escola de Enfermagem de Ribeirão Preto-USP, sendo este espaço equipado com quatro câmeras suspensas, cada uma em um canto do teto, com capacidade de registrar imagens e falas das pessoas presentes na sala sob diferentes ângulos. Os equipamentos de operacionalização de áudio e vídeo estavam alocados em uma antesala e permaneceram ligados no transcorrer dos encontros, após testagem prévia do equipamento e assessoria técnica prestada por funcionários da Escola de Enfermagem de Ribeirão Preto.

Embora inicialmente pensássemos que o uso de câmeras pudesse inibir as participantes deste estudo, isso não ocorreu, visto a localização das câmeras estar fora do alcance da visão dos sujeitos, incluindo-se os equipamentos de controle acima referidos.

O espaço físico do laboratório, embora pequeno, dispunha de dois armários que serviram de apoio para os pertences das mulheres estudadas enquanto participavam 
das oficinas, dispondo também de duas mesas localizadas ao centro e cadeiras em quantidade suficiente para acomodar todo o grupo.

A maioria das janelas permaneceu fechada por persianas, sendo que uma janela central foi propositalmente aberta para melhorar a iluminação do local e também para oferecer às participantes uma agradável visão do jardim, defronte ao laboratório, visando conferir ao ambiente uma sensação de tranqüilidade. Ressaltamos que essa janela não era suficientemente alta, mas, mesmo assim, garantiu total privacidade às participantes das oficinas.

Antes do início dos trabalhos com o grupo, organizávamos a sala de modo que as cadeiras ficassem dispostas em círculo ao redor das mesas, com vistas a facilitar a comunicação verbal e visual entre as participantes destes grupos; os materiais necessários para o desenvolvimento das técnicas empregadas nas oficinas eram dispostos sobre as mesas sendo que, sobre um dos armários laterais, o aparelho de som era posicionado.

A recepção das mulheres foi sempre um momento animado em que elas conversavam vários assuntos entre si e, após sentarem-se, era-lhes distribuídos crachás de identificação e solicitado para que, em círculo, dissessem seus nomes em voz alta. Embora se conhecessem previamente por participarem do REMA, esta técnica facilitou o entrosamento e o reconhecimento mútuo, também favorecendo maior contato visual entre elas.

Posteriormente a essa técnica, reforçávamos às mulheres para que falassem alto e devagar, durante as atividades do grupo, para que as câmeras pudessem registrar imagem e som, adequadamente. 
Primeiro encontro. Tema: Corpo e cirurgia: como me vejo após a cirurgia?*

\begin{tabular}{|l|l|l|}
\hline \multicolumn{1}{|c|}{ TÉCNICAS } & \multicolumn{1}{|c|}{ DESCRIÇÃO } & \multicolumn{1}{c|}{ OBJETIVOS } \\
\hline $\begin{array}{l}\text { Relaxamento dirigido } \\
\text { (Aquecimento) }\end{array}$ & $\begin{array}{l}\text { Solicitado às participantes, } \\
\text { sentadas nas cadeiras, em } \\
\text { posição confortável e de olhos } \\
\text { fechados, ao som de uma música } \\
\text { suave, que respirassem } \\
\text { lentamente imaginando cenas } \\
\text { agradáveis; que massageassem, } \\
\text { relaxando progressivamente, dos } \\
\text { pés ao rosto em em seguida, se } \\
\text { proposto. à discussão do tema } \\
\text { dessem um "auto-abraço", } \\
\text { abrindo lentamente os olhos. } \\
\text { A seguir, foi pedido que cada } \\
\text { uma expressasse o que sentiu e } \\
\text { pensou durante o relaxamento. }\end{array}$ \\
\hline $\begin{array}{l}\text { Apreciação de desenho de uma } \\
\text { mulher nua } \\
\text { (Desenvolvimento do tema) }\end{array}$ & $\begin{array}{l}\text { Solicitado para que o grupo } \\
\text { relacionasse, espontaneamente, } \\
\text { cada parte do corpo da mulher } \\
\text { desenhada a uma palavra. }\end{array}$ & $\begin{array}{l}\text { Pensar sobre as representações } \\
\text { que tem sobre o próprio corpo } \\
\text { após a cirurgia. }\end{array}$ \\
\hline $\begin{array}{l}\text { Música Maria Maria (cantada } \\
\text { por Elis Regina) } \\
\text { (Síntese e Encerramento) }\end{array}$ & $\begin{array}{l}\text { Entrega da letra da música a a } \\
\text { cada participante. }\end{array}$ & $\begin{array}{l}\text { Encerrar o encontro, após } \\
\text { reflexões e síntese. }\end{array}$ \\
\hline
\end{tabular}

* Todas as quatro oficinas foram baseadas e adaptadas de Afonso e Pinto (2002).

A técnica de relaxamento proposta consistiu em que as participantes fechassem os olhos, ao som de uma música instrumental, iniciando uma massagem lenta a partir dos tornozelos e, sob nossas orientações, massageassem outras partes do corpo até chegar à cabeça. Durante esta automassagem, deveriam também imaginar cenas agradáveis, que lhes trouxessem tranqüilidade sendo que, ao final do relaxamento deveriam abraçar o próprio corpo de uma forma afetiva.

$\mathrm{O}$ envolvimento das mulheres nessa fase de aquecimento foi inicialmente relutante, sendo observado que durante o início do relaxamento duas participantes não conseguiram fechar os olhos, conforme solicitado.

Porém, antes do término dessa atividade elas conseguiram se envolver no relaxamento seguindo nossas orientações, no sentido de massagearem partes do próprio corpo, de forma gradual.

Após o encerramento do relaxamento, solicitamos às mulheres para que abraçassem o próprio corpo e ao final abrissem os olhos, momento em que sugerimos para que expressassem o que sentiram durante a realização do mesmo. Algumas mulheres disseram ter relaxado e ter conseguido imaginar cenas agradáveis, sendo que uma delas emocionou-se e chorou referindo-se particularmente à necessidade que sentia 
de ser abraçada e apoiada em suas dificuldades pessoais, situação a que o grupo concordou prontamente.

Levando em consideração a necessidade expressa pelas mulheres, no sentido de desejarem ser abraçadas e tocadas, sugerimos a elas que a técnica de relaxamento fosse mantida ao longo dos encontros, particularmente no início de cada oficina, sendo que o grupo aceitou a proposta.

Posteriormente, apresentamos às participantes o tema desta oficina e solicitamos para que observassem, uma por vez, um cartaz com um desenho de uma mulher nua com as mamas perfeitas, desenho este reproduzido de um livro de anatomia humana: uma mulher em posição ortostática com o olhar direcionado ao horizonte, pernas semi abertas e palmas das mãos voltadas para frente.

Posteriormente a essa observação, as mulheres deveriam avaliar o que sentiram diante da figura desenhada, inicialmente por meio de uma palavra e depois através de comentários livres.

Foi observado que as participantes não atenderam integralmente a esta proposta, pois na medida em que observavam o desenho iniciavam comentários acerca de suas impressões pessoais para com a ilustração em questão. Isso não comprometeu os objetivos deste encontro, pois os discursos evidenciaram diferentes impressões e representações das mulheres a partir da apreciação do desenho, comparando-o com o próprio corpo.

Ao término destes comentários, solicitamos ao grupo para que selecionasse e refletisse sobre os principais aspectos vivenciados no encontro, sendo que as mulheres discutiram acerca de como as percepções sobre um corpo considerado perfeito podem ser diferentes.

As mulheres mostraram satisfação por terem participado desta primeira oficina, por meio de verbalizações e sorrisos. Questionamentos do tipo "estamos respondendo certo?" foram constantes, lhes sendo respondido que estas oficinas não pretendiam discutir valores como certo ou errado, mas valorizar as contribuições dadas por cada participante.

Antes do encerramento deste encontro, distribuímos às mulheres folhas de papel sulfite com a letra da música Maria Maria, interpretada por Elis Regina, para que pudessem acompanhar a música tocada no aparelho de som e refletissem sobre as 
similaridades e diferenças desta música para com suas próprias vidas. Todas as participantes mostraram-se bastante entusiasmadas com a música, dizendo existir muitas coisas em comum entre a música e sua experiência com relação ao câncer de mama.

Nesse momento, referindo-se à letra da música, uma participante verbalizou que “... é muito parecido com a gente na hora que fala que é preciso ter força e que a gente tem uma marca no corpo, mas tem fé na vida”.

Após o término desta oficina e despedida das participantes, procedemos a uma discussão sobre nossas percepções acerca do trabalho realizado neste primeiro encontro. Nossas impressões pessoais foram positivas, tornando possível considerar que esta oficina atendeu aos objetivos propostos.

Segundo encontro. Tema: Corpo e atividades da vida diária (AVDs)

\begin{tabular}{|c|c|c|}
\hline TÉCNICAS & DESCRIÇÃO & OBJETIVOS \\
\hline $\begin{array}{l}\text { Relaxamento dirigido } \\
\text { (Aquecimento) }\end{array}$ & $\begin{array}{l}\text { Solicitado às participantes, } \\
\text { sentadas nas cadeiras, em } \\
\text { posição confortável e de olhos } \\
\text { fechados, ao som de uma música } \\
\text { suave, que respirassem } \\
\text { lentamente imaginando cenas } \\
\text { agradáveis; que massageassem, } \\
\text { relaxando progressivamente, dos } \\
\text { pés ao rosto e, em seguida, se } \\
\text { dessem um "auto-abraço", } \\
\text { abrindo lentamente os olhos. } \\
\text { A seguir, foi pedido que cada } \\
\text { uma expressasse o que sentiu e } \\
\text { pensou durante o relaxamento. }\end{array}$ & $\begin{array}{l}\text { Descontrair e criar um clima } \\
\text { propício à discussão do tema } \\
\text { proposto. }\end{array}$ \\
\hline $\begin{array}{l}\text { Apresentação ao grupo do } \\
\text { elenco das AVDs para reflexão } \\
\text { em duplas. } \\
\text { (Desenvolvimento do tema) }\end{array}$ & $\begin{array}{l}\text { AVDs descritas em folhas de } \\
\text { papel, apresentadas ao grupo } \\
\text { para apreciação. O grupo foi } \\
\text { separado em duplas para refletir } \\
\text { sobre o significado e o sentido } \\
\text { das AVDs em suas vidas. } \\
\text { Posteriormente, cada dupla } \\
\begin{array}{l}\text { apresentou ao grupo o que } \\
\text { discutiu. }\end{array}\end{array}$ & $\begin{array}{l}\text { Informar as diferentes AVDs; } \\
\text { Identificar o significado e } \\
\text { importância da realização das } \\
\text { atividades da vida diária para as } \\
\text { mulheres, após a cirurgia. }\end{array}$ \\
\hline $\begin{array}{l}\text { Caixinha de surpresas } \\
\text { (Síntese e encerramento) }\end{array}$ & $\begin{array}{l}\text { 1) Cada pessoa escreve a (s) } \\
\text { atividade(s) que gostaria (m) de } \\
\text { discutir no grupo, sem } \\
\text { identificar-se; } \\
\text { participante retira um bilhete da } \\
\text { caixa e responde a ele, dizendo o } \\
\text { que faria caso estivesse no lugar } \\
\text { da pessoa que o escreveu; 3) O } \\
\text { grupo faz um levantamento dos } \\
\text { problemas e soluções que mais } \\
\text { apareceram e sua relação com a } \\
\text { vida das participantes. }\end{array}$ & $\begin{array}{l}\text { Estimular o compartilhamento } \\
\text { de experiências sobre estratégias } \\
\text { para minorar dificuldades na } \\
\text { realização das AVDs. }\end{array}$ \\
\hline
\end{tabular}


Para iniciar a oficina "Corpo e atividades da vida diária (AVDs), foi realizado o relaxamento dirigido, à semelhança do primeiro encontro. Observamos a participação de todas as mulheres sendo que, durante o auto-abraço, a expressão de satisfação no semblante das mulheres foi evidente, traduzida por sorrisos.

Posteriormente, para o desenvolvimento do tema desta oficina, distribuímos às mulheres folhas impressas com uma lista de AVDs, para que cada participante pudesse apreciá-las individualmente, durante aproximadamente cinco minutos.

Após esta apreciação, solicitamos às mulheres para que se separassem em duplas e buscassem discutir, com seus pares, durante um período de cinco a dez minutos, sobre o sentido destas AVDs em suas vidas. Especificamente, sobre como essas atividades têm sido realizadas por elas após a cirurgia por câncer de mama e qual o significado desta realização. As orientações oferecidas às duplas acerca desta etapa da oficina foi para que utilizassem todo o espaço da sala que ocupavam, não necessitando ficar sentadas em círculo.

Reforçamos para que não se preocupassem em discutir cada atividade em particular, visto que o objetivo desse momento foi buscar apreender o sentido geral da realização das AVDs, na perspectiva das mulheres, após a cirurgia.

Após a discussão, as duplas deveriam retornar aos seus lugares e formar novamente o grupo para apresentarem oralmente as questões discutidas propiciando uma reflexão grupal. O que se seguiu foi uma apresentação minuciosa de cada AVD separadamente, nesse sentido não atendendo à proposta dessa técnica, o que acabou por prolongar o tempo destinado a esta fase do encontro. Observamos que os depoimentos de grande parte das mulheres, nesse momento da oficina, não deixava transparecer quaisquer dificuldades vividas por elas no que tange à independência na realização de suas AVDs.

Algumas participantes expressaram dificuldades referentes à atividade de vestirse, por terem aumentado o peso corporal principalmente após o tratamento quimioterápico, situação considerada por elas como desmotivante, deixando-lhes insatisfeitas com a aparência do corpo; outras participantes expressaram dificuldades quanto à expressão sexual, referindo falta de interesse em relacionar-se sexualmente com os companheiros.

Seguiu-se, após a discussão acima, a etapa final deste encontro em que as mulheres foram orientadas a registrar, em pequenas folhas de papel, as AVDs que lhes 
apresentavam maiores dificuldades de desempenho sem, para isto, identificarem seus nomes nos bilhetes.

Após registro por escrito, os bilhetes foram recolhidos e colocados em uma caixa pequena, sendo solicitado para que cada participante retirasse desta caixa um bilhete para si. Em posse de um bilhete, cada participante deveria ler o conteúdo em voz alta e, diante das atividades ali registradas, ofereceriam sugestões no sentido de dizer ao grupo o que tem feito ou faria caso estivesse passando pelas mesmas dificuldades, no que se refere à realização das AVDs contidas no bilhete.

Encerrada a etapa acima descrita, foram feitas algumas orientações sobre possíveis estratégias e cuidados que as mulheres poderiam adotar em seu desempenho de AVDs, visando minorar algumas dificuldades expressas no grupo sendo, tais orientações, feitas pelas próprias participantes da oficina e também pelos coordenadores, fazendo emergir um compartilhamento de experiências.

Ao término desta oficina, discutimos nossas impressões, enquanto coordenadores do grupo. Consideramos que o excesso de atividades desenvolvidas neste encontro (reflexões em duplas e caixinha de surpresas) tornou o desenvolvimento do tema mais lento, pois tais atividades deveriam ser realizadas de acordo com regras específicas e encadeadas, o que tornou o grupo dependente de nossas instruções, impedindo a espontaneidade.

Para o próximo encontro, optamos propor às mulheres uma atividade desestruturada, com massa de modelar, por acreditarmos que a manipulação desse material possibilitaria ao grupo maior liberdade de expressão, mesmo mediante o tema pré-delimitado "Corpo e trabalho". 
Terceiro encontro. Tema: Corpo e trabalho

\begin{tabular}{|c|c|c|}
\hline TÉCNICAS & DESCRIÇÃO & OBJETIVOS \\
\hline $\begin{array}{l}\text { Relaxamento dirigido } \\
\text { (Aquecimento) }\end{array}$ & $\begin{array}{l}\text { Solicitado às participantes, } \\
\text { sentadas nas cadeiras, em } \\
\text { posição confortável e de olhos } \\
\text { fechados, ao som de uma música } \\
\text { suave, que respirassem } \\
\text { lentamente imaginando cenas } \\
\text { agradáveis; que relaxando } \\
\text { massageassem, a } \\
\text { progressivamente, dos pés ao } \\
\text { rosto e, em seguida, se dessem } \\
\text { um "auto-abraço", abrindo } \\
\text { lentamente os olhos. } \\
\text { A seguir, foi pedido que cada } \\
\text { uma expressasse o que sentiu e } \\
\text { pensou durante o relaxamento. }\end{array}$ & $\begin{array}{l}\text { Descontrair e criar um clima } \\
\text { propício à discussão do tema } \\
\text { proposto. }\end{array}$ \\
\hline $\begin{array}{l}\text { Modelagem em massa. } \\
\text { (Desenvolvimento do tema) }\end{array}$ & $\begin{array}{l}\text { Solicitado para que o grupo } \\
\text { modelasse com massa colorida a } \\
\text { imagem de uma mulher com } \\
\text { câncer de mama trabalhando. }\end{array}$ & $\begin{array}{l}\text { Estimular reflexões acerca das } \\
\text { limitações impostas pelo corpo } \\
\text { após a cirurgia; }\end{array}$ \\
\hline $\begin{array}{l}\text { Reflexões sobre o tema corpo e } \\
\text { trabalho. } \\
\text { (Síntese e Encerramento) }\end{array}$ & $\begin{array}{l}\text { Observação da figura modelada, } \\
\text { seguida de comentários livres. }\end{array}$ & $\begin{array}{l}\text { Identificar as representações que } \\
\text { se tem sobre o tema desta } \\
\text { oficina. } \\
\text { Facilitar a expressão e reflexão } \\
\text { acerca das atividades produtivas } \\
\text { e de trabalho após tratamento } \\
\text { por câncer mamário. }\end{array}$ \\
\hline
\end{tabular}

A terceira oficina foi iniciada com técnica de relaxamento, similar à do primeiro e segundo encontros do grupo, sendo novamente observado a adesão de todas as mulheres na atividade.

Após o relaxamento, os depoimentos evidenciaram que as participantes conseguiram relaxar e permanecerem tranqüilas, comentando ser importante a realização desta técnica também em casa, nos momentos em se sentiam mais cansadas em decorrência da realização das tarefas domésticas. Estes depoimentos deram possibilidade para a apresentação da proposta de atividade que se seguiu, enquanto parte do desenvolvimento do tema.

Foi solicitado às mulheres para que utilizassem os materiais dispostos sobre as mesas (massa para modelagem coloridas), no centro do círculo formado pelo grupo. As mulheres deveriam modelar uma figura que representasse uma mulher, com câncer de mama, trabalhando. Para isto, deveriam levantar-se de seus lugares e permanecerem em pé, ao redor da mesa, como forma de facilitar a manipulação do material. 
O envolvimento das mulheres nessa atividade foi bastante grande, inicialmente compartilhando idéias sobre como deveria ser a aparência da figura modelada, posteriormente dividindo tarefas. Cada participante ficou responsável por modelar em massa um segmento do corpo da escultura. A satisfação em participar dessa atividade chamou a atenção, sendo expressa no semblante sorridente das mulheres e por observações do tipo “...que legal, nunca pensei que um dia ia fazer isso” e também “ ...fomos pegas de surpresa, né...”.

No transcorrer dessa atividade, foram freqüentes as observações feitas pelas mulheres, no sentido de buscarem esculpir uma figura perfeita e simétrica: “... Eu vou fazer a cintura, ela tem uma cinturinha" e ainda "Ela é vaidosa, tem colar... usa brinco" ou "Ih! Um braço está maior que o outro" e, no tocante à cirurgia realizada pela figura em modelagem, o grupo decidiu que “... ela fez quadrante...”.

Os instrumentos modelados pelo grupo, que representavam as ocupações referentes ao trabalho da boneca esculpida, foram dois baldes, uma vassoura grande, um rodo, uma fita métrica e uma tesoura. As participantes, ao tentarem posicionar estes instrumentos na boneca modelada tiveram que enfrentar outro desafio: a escultura não parava em pé, devido ao peso desses instrumentos em sua estrutura frágil, ou seja, a própria massa utilizada para a modelagem.

Este aspecto foi por elas relacionado à sua própria vida, quando apontaram que o excesso de trabalho, para uma mulher que realizou cirurgia por câncer de mama, poderia debilitá-la.

Ao final da modelagem, o grupo acatou, de maneira bastante afetiva, a sugestão feita por uma participante de batizar a boneca esculpida com o nome de "Mariquinha", sendo que, após isso, todos passamos a nos referir à boneca de massa utilizando este nome. Consideramos importante destacar, também, o sentimento de satisfação dessas mulheres no sentido de terem obtido êxito na atividade proposta para essa oficina. Isso apareceu em discursos como “... a gente deu conta, né?” e também “...a gente é capaz $\operatorname{sim} . . . "$.

A discussão que se efetivou ao longo da etapa final dessa oficina foi centrada em torno das dificuldades vividas pelas mulheres estudadas, durante a realização de suas atividades relacionadas ao trabalho e também das estratégias adotadas por elas, na busca de se melhorar sua execução. 
Em nossas discussões pós-encerramento da oficina, consideramos que o encontro traduziu situações que as mulheres estudadas vivenciam em suas atividades produtivas. Nesse sentido, após o tratamento da doença oncológica, as mulheres passam a utilizar diferentes estratégias para a execução de suas atividades produtivas, por vezes sendo necessário a participação de outras pessoas para que seus afazeres se dêem de forma mais efetiva e harmônica.

Quarto encontro. Tema: Corpo e lazer.

\begin{tabular}{|c|c|c|}
\hline TÉCNICAS & DESCRIÇÃO & OBJETIVOS \\
\hline $\begin{array}{l}\text { Relaxamento dirigido } \\
\text { (Aquecimento) }\end{array}$ & 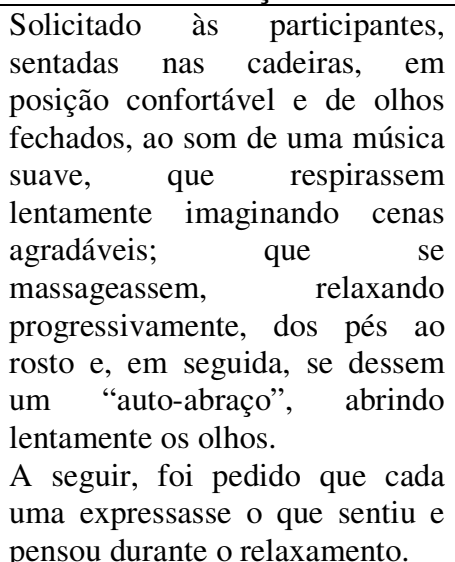 & $\begin{array}{l}\text { Descontrair e criar um clima } \\
\text { propício à discussão do tema } \\
\text { proposto. }\end{array}$ \\
\hline $\begin{array}{l}\text { Estrela de cinco pontas } \\
\text { (Desenvolvimento do tema) }\end{array}$ & $\begin{array}{l}\text { Solicitado para que cada } \\
\text { participante desenhasse em uma } \\
\text { folha de papel uma estrela de } \\
\text { cinco pontas registrando em seu } \\
\text { centro o tema desta oficina; em } \\
\text { cada ponta da estrela deveriam } \\
\text { registrar, sobre o tema, as } \\
\text { perguntas: 1. o que observam; } 2 . \\
\text { o que pensam; } 3.0 \text { que sentem; } 4 \text {. } \\
\text { como gostaria que fosse; } 5 . \text { o } \\
\text { que fazem em relação a esta } \\
\text { questão. }\end{array}$ & $\begin{array}{l}\text { Estimular reflexões acerca das } \\
\text { limitações impostas pelo corpo } \\
\text { na realização das atividades de } \\
\text { lazer; }\end{array}$ \\
\hline $\begin{array}{l}\text { Reflexões sobre o tema corpo e } \\
\text { lazer. } \\
\text { (Síntese e Encerramento) }\end{array}$ & $\begin{array}{l}\text { Expressão e reflexão sobre as } \\
\text { etapas da atividade realizada. }\end{array}$ & $\begin{array}{l}\text { Identificar as representações que } \\
\text { se tem sobre o tema desta } \\
\text { oficina. }\end{array}$ \\
\hline
\end{tabular}

Ao relaxamento proposto como aquecimento inicial deste encontro, seguiu-se a distribuição de folhas em branco e canetas coloridas às participantes, após orientações sobre como a atividade seria feita. Cada integrante do grupo desenhou uma estrela e registrou as questões pertinentes à discussão e reflexão do tema "Corpo e lazer", conforme apontado no quadro acima.

Após a elaboração dos desenhos, solicitamos para que o grupo discutisse o tema de acordo com a ordem das cinco questões registradas na folha de papel, o que não 
ocorreu, tendo sido observado uma livre discussão sobre o tema da oficina. Isso não comprometeu a qualidade de participação das mulheres nem os objetivos propostos para o desenvolvimento desta oficina.

As reflexões evidenciaram as dificuldades vividas pelas mulheres, durante a realização de suas atividades de lazer. Algumas apontaram desânimo de participar dessas atividades em grupos de amigos ou mesmo junto dos familiares, outras referiram ter optado por isolar-se, tanto quanto possível, de encontros sociais também junto dos familiares e amigos, ao passo que outras expressaram não vivenciar lazer por diferentes motivos.

Tendo em vista ter sido este o último encontro do grupo e por estar se aproximando o natal, propusemos aos presentes um abraço coletivo como forma de despedida, momento em que houve trocas de votos de felicidades e de boa saúde.

\subsection{Análise dos dados}

A análise de conteúdo foi utilizada, neste estudo, como base metodológica para a análise dos dados brutos obtidos, com vistas a depreender dos mesmos as unidades temáticas que auxiliaram a compreensão das representações sociais das mulheres com câncer de mama, sobre seu corpo, após tratamento por câncer de mama e suas implicações para o desempenho ocupacional.

Segundo Bardin (2004), por análise de conteúdo entende-se um conjunto de técnicas de análise das comunicações que, ao adotar procedimentos sistemáticos e objetivos para descrever o conteúdo das mensagens busca obter indicadores que possibilitam a inferência de conhecimentos relativos às condições de produção/ recepção destas mensagens. Essa modalidade de análise preocupa-se em desvelar o que está por trás das mensagens sobre as quais se debruça, buscando atingir realidades mais profundas que os seus conteúdos manifestos.

A análise de conteúdo possibilita o aprofundamento nos conteúdos tomados a partir de uma leitura de primeiro plano, na medida em que relaciona estruturas semânticas (significantes) com estruturas sociológicas (significados) destes conteúdos. Busca, assim, associar os conteúdos manifestos das mensagens aos fatores que determinam sua gênese: variáveis psicossociais, contexto natural e processo de produção da mensagem. 
Entre as técnicas passíveis de uso em análise de conteúdo de material qualitativo, estão a Análise de Expressão, Análise de Relações, Análise Temática e Análise de Enunciação, sendo as duas últimas técnicas merecedoras de destaque, uma vez que se adequam mais efetivamente em pesquisas qualitativas sobre saúde (MINAYO, 1999).

Levando-se em consideração o exposto acima, neste estudo, procedemos à análise dos dados empregando a Análise Temática.

A realização de uma análise temática consiste em descobrir os núcleos de sentido componentes de uma comunicação cuja presença ou freqüência signifiquem alguma coisa para o objetivo analítico visado. Tradicionalmente, a análise temática se encaminha para a contagem de frequiência das unidades de significação como definitórias do caráter do discurso. Em termos qualitativos, a presença de determinados temas denota os valores de referência e os modelos de comportamento presentes no discurso (MINAYO, 1999).

Em relação à organização e utilização da técnica, existem fases distintas na análise de conteúdo, organizadas em três pólos cronológicos, que seguimos para a execução deste estudo, sendo elas: 1) Pré-análise; 2) Exploração do material e 3) Tratamento dos resultados (BARDIN, 2004).

\section{1) Pré-análise}

Esta fase compreende procedimentos para a organização do material selecionado para a análise, de forma a facilitar e sistematizar as idéias iniciais. Desdobra-se em três missões, sendo a primeira missão correspondente à escolha dos documentos a serem analisados (BARDIN, 2004).

Neste estudo, tais documentos foram constituídos pelos dados transcritos após cada oficina de reflexão.

Dentre os procedimentos característicos da fase pré-analítica, encontram-se a leitura flutuante dos documentos escolhidos para a análise e a constituição do corpus (MINAYO, 1999).

A leitura flutuante consiste em um procedimento pelo qual o pesquisador, em posse dos documentos escolhidos, inicia um processo de leitura e análise do material, 
deixando-se invadir por impressões e orientações. Este procedimento possibilita tornar a leitura mais precisa, em função das hipóteses emergentes (BARDIN, 2004).

A constituição do corpus refere-se a organização do material com vistas a responder a critérios de validade, tais como: a exaustividade, que atende a todos os aspectos levantados no roteiro; a representatividade, que contém a representação do universo pretendido; a homogeneidade, que reporta-se a normas específicas de escolha acerca dos temas, técnicas e interlocutores; a pertinência, que orienta para que os documentos analisados adaptem-se aos objetivos da pesquisa (MINAYO, 1999).

A segunda missão, relacionada à etapa de pré-análise, corresponde à formulação de hipóteses (pressupostos) e dos objetivos: uma hipótese é uma afirmação provisória que nos propomos a verificar (confirmar ou infirmar), recorrendo aos procedimentos de análise. O objetivo é a finalidade geral a que nos propusemos ou que é fornecida por uma instância exterior, o quadro teórico e/ ou pragmático, no qual os resultados obtidos serão utilizados (BARDIN, 2004).

Em se tratando de material qualitativo, os pressupostos iniciais devem ser formulados de maneira flexível visando possibilitar a emergência de novas hipóteses a partir de procedimentos exploratórios. Deve-se atentar para a importância de se elaborar hipóteses iniciais, pois a realidade não é evidente, mas responde a questões que teoricamente lhe são apresentadas (MINAYO, 1999).

A terceira missão da fase pré-analítica é delimitada pela referenciação dos índices e a elaboração de indicadores. Nesta fase, as unidades de registro são determinadas (palavras-chave ou frases), assim como a unidade de contexto, os recortes, as formas de categorização e de codificação, também os conceitos teóricos que guiarão a análise (BARDIN, 2004; MINAYO, 1999).

Para Bardin (2004), apesar dos fatores descritos serem interdependentes, não necessariamente se organizam mediante uma ordem cronológica. Portanto:

\footnotetext{
[...] a escolha de documentos depende dos objetivos, ou, inversamente, o objetivo só é possível em função dos documentos disponíveis; os indicadores serão construídos em função das hipóteses, ou, pelo contrário, as hipóteses serão criadas na presença de certos índices (p.89).
}

Nesta fase de pré-análise, os dados coletados durante as oficinas de reflexão foram transcritos integralmente após a realização de cada oficina. As falas das mulheres 
foram registradas por escrito associando, tais discursos, aos grupos dos quais emergiram. Cada um dos quatro grupos foi identificado, respectivamente, pelas siglas G1, G2, G3 e G4, como forma de facilitar a visualização inicial dos temas emergentes em cada grupo.

Assim, os documentos selecionados para análise temática, neste estudo, foram os discursos transcritos após a consecução de cada oficina de reflexão, com vistas a responder ao pressuposto de que a imagem corporal, pós-tratamento por câncer mamário, independentemente da cirurgia realizada pelas mulheres, configura fator interferente em seu desempenho ocupacional.

\section{2) Exploração do material}

A fase de exploração do material remete-se às operações de codificação, classificação e categorização dos temas, obtidos por meio da transformação dos dados brutos, com a finalidade de se alcançar núcleos de compreensão do texto. Os textos são desmembrados em unidades sendo posteriormente reagrupados de acordo com seus conteúdos semelhantes (BARDIN, 2004).

Segundo Minayo (1999), é nesta fase da análise temática que se deve proceder a recortes do texto em unidades de registro por uma palavra, uma frase, um tema, um acontecimento, tal qual estabelecido na pré-análise. Posteriormente, procede-se a seleção das regras de contagem ou de convergência de significados. Finalmente, efetuase a classificação e a agregação dos dados, selecionando as categorias teóricas ou empíricas que nortearão a especificação dos temas.

O procedimento de leitura flutuante, neste estudo, nos possibilitou um aprofundamento com os dados transcritos após a realização de cada oficina de reflexão. Nesta etapa, procedemos a um primeiro agrupamento dos dados de acordo com os temas previamente delimitados para cada oficina, ou seja: 1) Corpo e cirurgia; 2) Corpo e atividades da vida diária (AVD); 3) Corpo e trabalho e 4) Corpo e lazer.

Embora cada oficina de reflexão tenha sido planejada para a abordagem específica de um tema a cada encontro, observamos que os temas não ficaram circunscritos à sua oficina temática, em particular. Ao contrário, foi clara a emergência desses temas em todas as oficinas de reflexão. Assim, como exemplo, o tema corpo e trabalho foi objeto de discussão entre as mulheres estudadas na primeira, segunda, terceira e quarta oficinas e não somente no terceiro encontro, planejado para tal tarefa. 
No presente estudo, ainda ao longo da leitura flutuante dos dados transcritos, foi possível efetivar um segundo reagrupamento dos mesmos, de acordo com as idéias similares que emergiram dos discursos das mulheres estudadas. Após releituras exaustivas do material transcrito foi possível identificar duas categorias analíticas nas quais os dados se enquadraram: 1) Corpo e tratamento; 2) Corpo e fazer.

As duas categorias de análise mencionadas, aparentemente separadas, mostraram-se inter-relacionadas e comandaram o processo de análise e discussão dos dados, permitindo apreender as representações das mulheres estudadas acerca de seu corpo, após tratamento por câncer de mama, e suas repercussões para o desempenho de suas atividades.

Em relação à categoria analítica "Corpo e tratamento", foram identificadas as seguintes unidades temáticas, a partir das falas das mulheres estudadas: alterações na aparência do corpo, corpo limitado, representações que lhes suscitaram sentimentos de fragilidade, revolta e conformismo.

No que tange à segunda categoria de análise "Corpo e fazer", as mulheres trouxeram representações sobre o impacto do tratamento do câncer de mama para seu corpo, nas três áreas de desempenho ocupacional, ou seja: AVDs; atividades produtivas e do trabalho; atividades de lazer. As unidades temáticas concernentes a esta categoria foram aqui abordadas separadamente, segundo a área de desempenho ocupacional afetada. Foram elas:

- Atividades da vida diária: corpo limitado na execução de AVDs; continuidade na execução de AVDs;

- Atividades produtivas e de trabalho: corpo limitado no desempenho de atividades produtivas e de trabalho; continuidade no desempenho de atividades produtivas e de trabalho.

- Atividades de lazer: Limitações para a prática do lazer.

\section{3) Tratamento dos resultados}

Nesta etapa da análise temática do conteúdo, os resultados brutos são submetidos a operações que permitem colocar em relevo informações obtidas. Assim, este procedimento possibilita ao analista propor inferências e interpretar os dados obtidos de acordo com seu quadro teórico ou com os objetivos previstos pela pesquisa. 
Nesse sentido, possibilita também a elaboração de sugestões para futuros estudos e fornece subsídios para uma proposta de intervenção adequadas à problemática exposta.

$\mathrm{Na}$ presente etapa, ao colocarmos em relevo os dados obtidos, pudemos estruturar o esquema abaixo, que orientou nossa análise dos dados:

\begin{tabular}{|c|c|}
\hline CATEGORIAS ANALÍTICAS & UNIDADES TEMÁTICAS \\
\hline 1) Corpo e tratamento & $\begin{array}{l}\text { - Alterações na aparência do corpo } \\
\text { - Corpo limitado } \\
\text { - Fragilidade, revolta e conformismo }\end{array}$ \\
\hline 2) Corpo e fazer & $\begin{array}{l}\text { - Atividades da vida diária: } \\
\text { corpo limitado na execução de AVDs (quanto aos } \\
\text { cuidados pessoais; mobilidade na comunidade e } \\
\text { comunicação funcional; expressão sexual) } \\
\text { continuidade na execução de AVDs (quanto aos } \\
\text { cuidados pessoais; socialização; manutenção da } \\
\text { saúde) } \\
\text { - Atividades produtivas e do trabalho: } \\
\text { corpo limitado no desempenho de atividades } \\
\text { produtivas e do trabalho (quanto ao controle } \\
\text { domiciliar; cuidados com os outros e execução de } \\
\text { trabalho remunerado) } \\
\text { continuidade no desempenho de atividades } \\
\text { produtivas e do trabalho (quanto ao controle } \\
\text { domiciliar; cuidados com os outros e execução de } \\
\text { trabalho remunerado) } \\
\text { - Atividades de lazer: } \\
\text { limitações para a prática do lazer }\end{array}$ \\
\hline
\end{tabular}

Apresentamos, a seguir, os resultados e discussão, baseado no esquema acima exposto. 


\section{RESULTADOS E DISCUSSÃO}

\subsection{Categorias analíticas}

\subsubsection{Corpo e tratamento}

Os discursos das mulheres estudadas sofreram recortes de acordo com os trechos que denotaram as representações, feitas por elas, sobre o próprio corpo, após o tratamento do câncer de mama. Estes depoimentos foram agrupados segundo a convergência de idéias presentes nestes discursos.

Por meio do agrupamento desses conteúdos, foram identificadas as seguintes unidades temáticas: alterações na aparência do corpo, corpo limitado, representações que suscitaram nas mulheres estudadas sentimentos contraditórios de fragilidade, revolta e conformismo.

\section{Alterações na aparência do corpo}

As mulheres estudadas reportaram-se a diferentes representações sobre a aparência do próprio corpo, após terem recebido tratamento cirúrgico e quimioterápico por câncer de mama.

Em relação às modalidades cirúrgicas a que foram submetidas, as mulheres expuseram em seus relatos diferentes formas de avaliação para com a imagem corporal.

Neste estudo, mulheres que realizaram tratamentos cirúrgicos conservadores como quadrantectomia, seguida ou não de cirurgia plástica para diminuição do volume da mama contralateral e nodulectomia, referiram maior insatisfação com a imagem corporal frente aos resultados estéticos do pós-operatório do que as mulheres que fizeram excisão total das mamas.

As mulheres submetidas a mastectomia unilateral (sem reconstrução da mama) e também mastectomia bilateral (seguida de cirurgia de reconstrução imediata das mamas) não verbalizaram incômodo com a imagem do corpo.

No tocante às mulheres que receberam tratamento cirúrgico conservador, suas falas expressaram a percepção sobre a imagem corporal modificada quando passaram a 
observar, mais notadamente, diferenças no tamanho das mamas. Seus depoimentos indicaram que, embora tenham se submetido aos tratamentos em questão, a atenção voltada para com a imagem corporal persiste e pode vir a incomodar independentemente da idade e ou da preservação parcial das mamas. São seus depoimentos:

“... eu noto que a minha mama direita está maior do que a esquerda... Uns dois meses para cá que notei... Então, outro dia, eu fiquei pensando, gente, será que agora eu fiz. 53 anos que eu fui olhar isso?"

“... parece que um está maior... um peito está maior que o outro”

“... o meu seio... olha tanto que um é maior que o outro...” (G1).

"Então, o seu também, né, eu pensei que fosse só a minha... Ainda das outras é tudo menor, a minha é maior, parece que está... sei lá.” (G3).

Nas falas acima, percebemos um senso de identificação entre as depoentes, quando atentam à situação comum de portarem mamas assimétricas, especialmente após o tratamento do câncer de mama.

As mamas, em termos anatômicos, apresentam pequenas alterações no tamanho, o que talvez nunca tenha sido observado pelo grupo estudado, sendo focado somente a partir da cirurgia. Assim, o câncer mamário e seu tratamento tornam-se responsáveis pela percepção da assimetria entre as mamas que, no presente estudo, configurou fator de atenção para com a aparência do corpo, por parte das mulheres.

O que as mulheres aprendem ao longo da vida sobre a estética corporal é que o corpo feminino se constitui por caracteres secundários sendo, um deles, representados pelas mamas. A mastectomia, ao extirpá-las parcial ou totalmente, acarreta às mulheres sentimentos de tristeza e estranheza que podem perdurar (FERREIRA, 1999; FERREIRA; MAMEDE, 2003).

Ao longo da História, a valorização da simetria representou, de alguma forma, a ordem e a beleza estética do mundo, tendo sido abordada em diferentes áreas do conhecimento, como as Artes Plásticas, a Mitologia e a Filosofia (AMARAL, 1991).

Nesse sentido, para Etcoff (1999), artistas e pensadores como Leonardo da Vinci, Albrecht Dürer e Leon Battista Alberti buscaram retratar em suas obras as proporções geométricas e harmônicas do corpo humano, consideradas por eles como referenciais para a beleza humana. A simetria era concebida por estes eruditos como a 
relação e exata correspondência entre as partes do corpo, sendo este medido por palmos e outras formas de mensuração.

Atualmente, o termo simetria designa a correspondência precisa das formas dos lados opostos do corpo, estabelecendo uma harmonia a partir da linha mediana imaginária que o separa em duas partes (ETCOFF, 1999).

Diante do exposto, no caso das mulheres com câncer mamário, aqui estudadas, o incômodo gerado pela percepção de uma parte do corpo (a mama) proporcionalmente diferente da outra parece revelar a introjeção dos valores históricos e culturalmente atribuídos à simetria: como sendo sinônimos de beleza, perfeição e funcionalidade.

Neste estudo, a insatisfação com a aparência do corpo foi mais explícita em mulheres que receberam tratamento cirúrgico conservador das mamas, ao contrário daquelas submetidas às formas mais radicais de cirurgia.

Isso nos leva a concordar com Conde et al. (2006) e também Maluf, Mori e Barros (2005), ao apontarem a literatura científica inconclusiva ao afirmar que mulheres submetidas a tratamentos conservadores por câncer mamário teriam menos dificuldades com a imagem corporal, do que aquelas que realizaram mastectomia.

As mulheres aqui estudadas, submetidas a mastectomia, verbalizaram maior aceitação com a imagem corporal, o que nos faz considerar diferentes possibilidades que as levaram a essa aceitação, pois a severidade dos prejuízos estéticos decorrentes da extirpação total das mamas tende a ser mais significativa, quando em comparação com as outras participantes deste estudo, que tiveram seus corpos melhor preservados por cirurgias conservadoras.

Foram suas falas:

“Eu me sinto cem por cento perfeita (após mastectomia)”.

"Para mim é um corpo normal, eu não tive problema nenhum."

“Eu não me sinto inferior... porque está me faltando um pedaço (uma mama)” (G1).

Ao considerarmos os valores históricos atribuídos à simetria do corpo, também à sua funcionalidade e integridade física, é esperado que a extirpação total das mamas, metonímia do feminino, acarrete às mulheres operadas por câncer problemas relevantes com a imagem corporal, visto ter sido a mutilação mais agressiva e aparente tornando- 
as menos responsivas às expectativas culturalmente valorizadas para com a aparência do corpo feminino.

Acreditamos que essa aceitação, por parte das mastectomizadas, em relação à própria imagem corporal, pode ser atribuída a diferentes possibilidades.

Em um primeiro momento, seus depoimentos fazem transparecer uma rejeição de possíveis dificuldades vividas em relação à imagem corporal, pós-mastectomia. Isto pode atuar no sentido de minorar o sofrimento por elas vivido, quando da percepção de portarem corpos dissonantes do padrão social vigente, devido à mutilação decorrente da cirurgia.

Acresce-se, a essa situação, o fato de terem de lidar constantemente com a imagem corporal distorcida pela mastectomia, o que é representativo da condição de portarem uma doença crônica culturalmente associada à morte, ou seja, o câncer das mamas. Frente ao incômodo gerado pelo temor da recidiva do tumor, adotam formas para aliviar-se emocionalmente, nesse sentido, abstendo-se de assumirem quaisquer problemas associados à doença oncológica, a exemplo da imagem do corpo modificada pelo tratamento.

Outra possibilidade para que as mastectomizadas deste grupo se mostrem satisfeitas quanto à imagem corporal, associa-se à crença de que, ao livrar-se das mamas, por meio da cirurgia, livram-se definitivamente do câncer. Nesse sentido, o alívio emocional e a satisfação das depoentes podem traduzir a idéia de cura da doença oncológica, o que facilita a vivência de uma imagem corporal de forma não problemática, mesmo modificada.

A ausência de problemas com a imagem corporal das mulheres mastectomizadas também pode ser explicada pelo fato de adotarem formas adaptativas para ocultar a mutilação, pós-mastectomia. O uso de adaptações no vestuário favorece, nesse sentido, conforto emocional, possibilitando às mulheres a participação na vida social, sem se sentirem expostas, o que emerge de suas falas, no transcorrer deste estudo.

Devemos considerar, ainda, que a percepção das mulheres mastectomizadas sobre o próprio corpo, após o tratamento, pode ser influenciada por diferentes fatores, como a filosofia de vida adotada por elas, a estrutura psicológica e emocional, o apoio familiar recebido após o diagnóstico da doença ou mesmo a forma pela qual lidavam 
com a imagem corporal, anteriormente ao acometimento do câncer de mama (SILVA; MAMEDE, 1998).

Assim, os aspectos acima sublinhados podem favorecer maior aceitação com a situação vivenciada em relação à doença, à mastectomia e à imagem corporal, o que transparece, em parte, nas falas do grupo aqui estudado.

No que concerne à evitação de problemas para com a imagem corporal, pelas mulheres estudadas, decorrentes da extirpação total das mamas, propomos a explicação subseqüente.

Ao analisar o conteúdo dos discursos anteriormente expostos, apesar das depoentes afirmarem-se íntegras no que se refere ao corpo verbalizando não se sentirem "inferiores", apresentarem um corpo "normal" e estarem "perfeitas", estes termos, por elas utilizados para designar o próprio corpo, refletem atributos corporais culturalmente sancionados que remetem a um padrão corporal associado a ideais de perfeição, integridade física e funcionalidade, a que elas deixam de corresponder após a mastectomia.

Nesse sentido, os indivíduos que não se sentem "inferiores" quanto à imagem corporal, o fazem em relação a uma imagem padrão de corpo aceita na internalidade dos sistemas culturais, que conferem ao corpo valorações de inferioridade ou superioridade; o mesmo ocorre com aqueles que se sentem "normais" e "perfeitos" com os próprios atributos corporais, pois, assim, os designam em comparação com ideais de normalidade/ anormalidade, perfeição/ imperfeição valorizados ou não na sociedade, quanto à forma sobre como se deve aparentar o corpo.

Diante do que foi exposto, as mulheres aqui estudadas, ao adotarem os referidos termos para afirmarem-se íntegras quanto à imagem corporal, o fazem procedendo a comparações com imagens de corpos culturalmente valorizadas, para elaborarem sua conclusão, o que pode ser um indicativo de preocupação com a imagem corporal pósmastectomia, mesmo que seus discursos não traduzam, com clareza, esta problemática.

Para Rodrigues (1986), o homem, ao defrontar-se com situações que lhes fogem ao controle pode experimentar uma sensação de caos iminente. Para lidar com tais situações utiliza-se de meios técnicos e simbólicos por serem, estes códigos, geradores de um senso de organização que coloca o medo e a confusão vivida em uma realidade externa e separada à dele. Esses meios dos indivíduos controlarem coisas anômalas 
representam uma reação contra algo ameaçador sendo, a intensidade desta reação uma evidência de que as coisas contraditadas lhes são socialmente valorizadas, mas que necessitam ser evitadas.

Diante da incapacidade do homem de ter uma experiência com sentido isolado das codificações do grupo social a que pertence, pode rejeitar determinados fenômenos, sendo esta rejeição representativa da necessidade de olhar os fenômenos que rejeita, pois, por oposição, exprime-se positivamente através deles, numa expressão em que seus conteúdos adquirem sentido através do que repelem (RODRIGUES, 1986).

No grupo estudado, a linguagem foi o meio simbólico utilizado pelas mulheres para representar sua percepção de um corpo isento de problemas. Essa representação atua dando forma, nesse sentido, à desorganização interna vivida frente à imagem corporal distorcida pós-mastectomia.

Ao se considerar a natureza insidiosa do câncer mamário, seu tratamento desfigurante e incerto, as mulheres experimentam um sentido de desorganização da vida frente à necessidade de lidar constantemente com o medo da morte, também atentado às alterações severas da imagem corporal pós-mastectomia, em seus aspectos funcionais e aparentes. Essa situação lhes exige uma estrutura emocional passível de assumir uma diversidade de formas podendo ser, uma delas, a evitação de assumirem o próprio corpo como problemático.

No caso das mulheres aqui estudadas, pelo fato de terem realizado cirurgia em tempo menor que um ano, acreditamos que haja dificuldades de se defrontarem, inicialmente, com as mudanças ocorridas na imagem corporal, pois após a mastectomia, sua reelaboração pode levar tempo (FERREIRA; MAMEDE, 2003).

Assim, para as mulheres estudadas, independentemente do procedimento cirúrgico a que foram submetidas, a observação da assimetria das mamas, em decorrência da cirurgia por câncer mamário, sinalizou a uma percepção de um corpo imperfeito estética e funcionalmente, não correspondendo, portanto, ao ideal de corpo feminino valorizado em nossa sociedade: aquele que apresenta mamas esteticamente íntegras, grandes, firmes e funcionais capazes de amamentarem, atuando na estimulação erógena, também na diferenciação dos gêneros (DUARTE; ANDRADE, 2003; FERNANDES，1997; GRADIM，2005; HECKERT，1995; KRYNSKI，1986; YALOM, 1998). 
A cirurgia por câncer de mama pode significar para a mulher operada a perda da totalidade corporal, assimetria e vergonha. Acentua sentimentos de inadequação com a imagem do corpo por sofrer este relevante impacto, fazendo com que a mulher passe a interagir constantemente com a idéia da perda de um segmento corporal (SILVA; MAMEDE, 1998).

Nesse sentido, qualquer desfiguração corporal causada por mutilação faz evidenciar uma assimetria, assinalando para um desequilíbrio físico e simbólico do qual o sujeito mutilado será, sempre, seu portador (AMARAL, 1991).

Em sua tese de doutoramento, Ferreira (1999) discorre sobre os processos vividos por mastectomizadas na relação consigo mesma e com o mundo, a partir da percepção do corpo mutilado pela cirurgia. Nesse estudo, as mulheres pesquisadas referiram comprometimentos em sua beleza física ao assumirem seus corpos como esteticamente assimétricos causando-lhes prejuízos funcionais como no equilíbrio postural e na marcha. Esta autora já vinha apontando que, a partir da percepção da imagem corporal alterada, as mulheres passavam a preocupar-se com a visibilidade da mutilação, visto serem as mamas órgãos externos e, portanto, suscetíveis aos olhares de outras pessoas.

A preocupação das mulheres aqui estudadas no sentido de estarem vulneráveis ao olhar e avaliação dos outros foi, também no presente estudo, objeto de discussão entre as depoentes:

\footnotetext{
“Eu... fiquei... não sei se sou eu que percebo... eu tenho um seio maior que o outro...Então eu comecei assim...a me adaptar né, as minhas roupas...é para...é para as pessoas não notarem...Para as pessoas não notarem...”

“... Na minha peça íntima, no sutiã... eu tento deixar um lado maior, para arrumar, as pessoas falam 'Não, está normal', mas eu acho que está um seio maior que o outro. Eu...(após a adaptação) acho que ninguém está me olhando, porque eu tinha a impressão que as pessoas olhavam direto pra os meus seios...Aí eu ficava incomodada com aquilo...não sei se é da minha mente, mas agora eu estou mais...tranqüila” (G2).
}

Os dados acima sinalizaram para o fato de que as mulheres estudadas, em situação de encontro com outras pessoas, atentam para a assimetria das mamas e sentem-se incomodadas e expostas nestas relações interpessoais.

Rodrigues (1986) aponta ser o corpo humano socialmente concebido e a análise da representação do corpo possibilita atingir as vias de acesso à estrutura de 
valores de uma sociedade particular. Este autor, ao discorrer sobre indivíduos que portam desvios de conduta, comenta que estes indivíduos não se auto-avaliam necessariamente de forma negativa, ou seja, o desvio por si não traz a seus portadores um significado pejorativo. Porém, um desvio de conduta passa a ser considerado como tal a partir da interação destes indivíduos (seus portadores) com outros ("normais") que compartilham de seu meio sociocultural e que atuam contra ou favoravelmente àquilo que eles apresentam em termos de comportamento.

Consideramos a observação deste autor extensiva para os casos de pessoas que trazem marcas físicas no corpo, a exemplo das mulheres aqui estudadas, pois as marcas corporais, decorrentes da cirurgia por câncer mamário (cicatrizes, mutilação total ou parcial) registram corpos diferentes dos de outras mulheres não acometidas pela doença.

Assim, as diferenças corporais percebidas enquanto um problema seria função da interação entre o sujeito (as mulheres com câncer de mama) e o sistema social total (outras pessoas de seu convívio), já que todos se vêem suscetíveis à ameaça simbolizada pela diferença em questão (a doença oncológica e seu tratamento mutilador).

Em seu estudo sobre sexualidade de mastectomizadas, afirmam Duarte e Andrade (2003) que as mulheres operadas, em contato com o mundo, apresentam fantasias e medos que fazem evidenciar o estigma da doença. Comentam ser comum casos de mulheres que evitam desnudar-se diante dos outros e, mesmo vestidas, temem que as pessoas percebam seu problema. Isto as fazem buscar cirurgias plásticas e adaptações nas roupas como forma de recuperar, para si e para os outros, a integridade corporal comprometida.

Desde os gregos antigos, o termo estigma alude a marcas corporais que evidenciavam algo de extraordinário ou mau sobre o status moral dos indivíduos que as apresentavam. Estes deviam ser excluídos de lugares públicos, pois os sinais produzidos em seus corpos, feitos com cortes ou fogo, denunciavam delitos cometidos por eles, categorizando-os como escravos, criminosos ou traidores. O termo continua sendo empregado à semelhança de seu sentido literal original, embora possa ser aplicado atualmente para designar um distúrbio físico ou degenerativo (GOFFMAN, 1988). 
O sujeito estigmatizado, ao assimilar os padrões da sociedade maior, torna-se altamente suscetível àquilo que os outros vêem como seu defeito, levando-o a concordar que, em certa medida, ele ficou abaixo do que realmente deveria ser. A vergonha se torna uma possibilidade central, que emerge quando o indivíduo percebe que um de seus atributos é impuro e pode imaginar-se como um não portador dele (GOFFMAN, 1988).

Neste estudo, as adaptações utilizadas pelas mulheres para recuperarem as imperfeições corporais foram apontadas por elas como algo que as deixaram menos expostas em seus relacionamentos interpessoais, na medida em que passaram a corresponder, em termos de aparência física, às exigências culturalmente sancionadas sobre o que se espera de um corpo feminino.

Foi a partir da constatação de que trazem no corpo marcas concretas, decorrentes de um câncer de mama e de seu tratamento cirúrgico, que as mulheres estudadas passaram a temer a possibilidade de serem avaliadas negativamente pelos outros, visto que tais marcas as diferenciam das pessoas que não tiveram a doença. Isto denuncia que sua percepção sobre as seqüelas do tratamento cirúrgico do câncer de mama adquire características de um estigma.

A condição estigmatizante por que passam portadores de deficiência física ou mutilações, no seu contato com o mundo, se efetiva pelo encontro deste sujeito com as pessoas que o cercam, podendo constituir-se em uma barreira psicossocial que interfere em seu estar no mundo e, portanto, nas relações interpessoais. A evidência da deficiência ou da mutilação aos outros faz surgir, para seu portador, diferentes formas de preconceito que podem se configurar em aversão e rejeição, também em atitudes comiserativas (AMARAL, 1991).

Para mulheres com câncer de mama, os aspectos acima expostos podem configurar em um de seus principais temores relacionados à doença. As mulheres estudadas deixaram transparecer estes temores ao assumirem-se mais atentas e preocupadas ante a visibilidade da assimetria das mamas em seu contato com os outros.

Diante disso, buscaram duas formas diferentes para atenuar esta situação desconfortável física e emocionalmente: utilizaram adaptações no sutiã, sob as vestes, para disfarçar a integridade física comprometida pela cirurgia, de modo a aproximaremse de um padrão corporal aceito por elas e pelos outros e também se afirmaram curadas 
do câncer. Ao se considerarem sobreviventes de uma doença culturalmente associada à morte, passaram a enquadrar-se na categoria dos indivíduos saudáveis, conforme apresentado no depoimento que se segue:

“... eu saio bastante, eu sou evangélica, eu vou...muito na igreja, é muita gente na minha casa, então é uma rotina muito... Aí começou a desinchar (a mama operada), aí ficou muito menor ainda...eu comecei a olhar mais ainda...Mas assim...é...Eu não fiquei com vergonha...eu acho que é porque eu não sou tímida..eи...eu sinto, eu gosto de falar, eu....eu tive câncer, eu...fui curada...né..." (G2).

Ao conceberem o câncer de mama como uma experiência vivida e superada, estas mulheres passaram a vivenciar seus contatos sociais de forma menos ameaçadora. Ao se considerarem livres de uma doença altamente temida por sua característica recidivante, deixaram de ameaçar as bases da existência de ambos os lados que participam destas relações, ou seja: delas e daqueles que com elas interagem.

Desse modo, como apontado por Goffman (1988), manipulam seu estigma de forma a imaginar-se livres de seu "atributo impuro": a doença e seu tratamento desfigurante.

Nesse sentido, os sujeitos estigmatizados tendem a buscar formas adaptativas para ocultar o estigma, estratégia denominada como acobertamento. O objetivo é reduzir a tensão, facilitando para si e para os outros uma redução dissimulada do estigma, também facilitando ao estigmatizado um envolvimento espontâneo nos contextos públicos de interação social (GOFFMAN, 1988).

O depoimento apresentado acima aponta que as mulheres com câncer de mama podem vir a optar pela continuidade de suas relações sociais, participando de espaços públicos mesmo diante da possibilidade de se sentirem expostas aos outros. A insatisfação para com as alterações corporais produzidas pela cirurgia pode ser acobertada com o uso de diferentes estratégias, fazendo com que as mulheres se sintam mais aliviadas emocionalmente, também socialmente integradas.

Ainda com relação às alterações na aparência do corpo, identificadas pelas mulheres estudadas, o tratamento quimioterápico foi apontado por elas como uma das causas de sua insatisfação com a aparência pessoal, pois, como relataram, lhes fez aumentar o peso corporal. 
Mcphail e Wilson (2000) referem-se à necessidade de se considerar este efeito colateral da quimioterapia (o ganho ponderal) como um aspecto que interfere na imagem corporal de mulheres com câncer de mama. Segundo estes autores, o aumento de peso corpóreo é comumente desconsiderado em estudos sobre avaliação da imagem corporal em mulheres com câncer mamário.

Nesse sentido, Maluf, Mori e Barros (2005) complementam que grande parte dos estudos dessa natureza tem focado o ajustamento psicológico das mulheres, comparando pacientes mastectomizadas com outras submetidas a cirurgias conservadoras. Assim, não trazem as repercussões do ganho ponderal sobre a imagem corporal das mesmas, enquanto um efeito adverso da quimioterapia.

Neste estudo, o aumento de peso foi considerado pelas mulheres como algo incômodo para com a aparência do corpo, como evidenciam os depoimentos abaixo:

\footnotetext{
“... a gente engorda, né... Eu... acho que devido à medicação, a gente tem que comer, senão se sente mal, né...” (G4).

“Engordei muito... Eu acho que é do tratamento (quimioterápico)...”

"Só não me sinto cem por cento (em relação ao corpo)... porquê virei uma baleia." (G1).
}

De acordo as falas anteriormente expostas, na ótica do grupo estudado alimentar-se adequadamente foi uma forma de minorar o sofrimento orgânico decorrente dos efeitos colaterais indesejáveis da quimioterapia, a exemplo de náuseas e vômitos. Este aspecto coincide com o que Correia (2005) observa, no sentido de que pacientes com câncer em quimioterapia, em condições nutricionais adequadas, respondem melhor ao tratamento do que pacientes desnutridos.

As mulheres, ao associar seu aumento de peso corporal ao tratamento quimioterápico, também consideram apresentar maior ansiedade durante este período. Seus depoimentos apontaram para o fato de seu aumento de peso decorrer de exageros na alimentação em resposta à ansiedade vivenciada ao longo desta terapia antineoplásica, também de outras experiências associadas a ela e à própria doença.

Para as depoentes, a experiência da realização da cirurgia por câncer de mama, considerada por elas como tendo sido um evento estressante, o temor diante da possibilidade da recidiva do tumor e de virem a submeter-se novamente à quimioterapia 
e responderem negativamente à mesma, caso este tratamento resulte em anemia, foram apontados como sendo situações ansiogênicas. Essas condições são apontadas como justificativas para o ganho ponderal também pela ingesta alimentar aumentada quando da ansiedade provocada pelas reflexões sobre as possibilidades de virem, novamente, a enfrentar tais situações indesejáveis. Seus discursos explicitam:

\footnotetext{
"Eu comia mais, enquanto estava fazendo a quimio, porque eu não queria perder nem um dia, porque... Se marca você chega lá, você não comeu, está fraca, o sangue não está normal... Então, eu comia, mas comia... o que precisava comer, eu não perdia nem um dia... Fico pensando, meu Deus 'ah, ela vai fazer mais umas dez quimioterapias...' pelo amor de Deus, chega, não...eu fico pensando 'eu não vou comer'...aí, еи como...” (G4).

"Eu acho assim, que é a tentação, você faz uma quimio e se pegar anemia tem que... aí você faz a cirurgia, a própria ansiedade, eu sou extremamente ansiosa. Eu não era para engordar do jeito que eu estou... Eu engordei muito...” (G1).

“Eu noto que a gente tem mais fome... não sei se é a ansiedade... se é a ansiedade, não sei o que é mas eu acho que, assim, de duas em duas horas, tem que comer... Parece que tem aquela ansiedade, eu não era assim não... Notei que depois da cirurgia, eu fiquei... ansiosa..." (G4).

“... eu lambisco demais, acho que é por isso que eu estou gorda... tipo assim... É um hábito, é um vício, toda hora a gente...vai lá e come qualquer coisa, acaba, às vezes, comendo além da conta..." (G2).
}

O aumento da ingesta alimentar em mulheres com câncer mamário em quimioterapia pode sinalizar uma forma inadequada sobre como estas pacientes respondem à ansiedade, o que conseqüentemente eleva seu peso. Acresce-se a isso o aumento da vulnerabilidade emocional e medo das mulheres durante a realização dessa terapia antineoplásica, notoriamente desfigurante, que atuam acentuando seu nível de ansiedade (MELO; ARAUJO; OLIVEIRA; ALMEIDA, 2002; MALUF; MORI; BARROS, 2005; COSTA; VARELLA; GIGLIO, 2002).

Entre as causas multifatoriais predisponentes para o aumento do peso corporal em mulheres com câncer de mama em quimioterapia, situam-se o uso de corticóides inclusos no tratamento quimioterápico, a labilidade emocional associada ao estresse psicológico que as fazem aumentar a ingesta alimentar, o início da menopausa durante a quimioterapia, ou ainda e presença de hipotireoidismo relacionado ao câncer mamário (GIGLIO, 2004).

Acresce-se a estas causas alterações metabólicas, também a redução de energia levando à diminuição das atividades físicas em decorrência dos sintomas de fadiga resultante da quimioterapia, que configuram fatores para explicar o aumento do peso 
corpóreo nestas mulheres (COSTA; VARELLA; GIGLIO, 2002; ISHIKAWA; DERCHAIN; THULER, 2005).

Estima-se que o ganho ponderal ao longo do tratamento quimioterápico de mulheres com câncer de mama varie de 2,1 a 5,9 quilos sendo que entre 50\% e $96 \%$ dessas mulheres apresentam aumento de peso. Ainda é esperado que $20 \%$ delas possa atingir mais de dez quilos durante tratamento quimioterápico (GIGLIO, 2004).

Em um estudo realizado por Costa, Varella e Giglio (2002), foram pesquisadas cento e seis mulheres com câncer de mama, visando avaliar as variações do peso corporal ao longo do tratamento quimioterápico. Os resultados deste estudo indicaram que no grupo submetido à quimioterapia adjuvante e neoadjuvante houve aumento de peso médio de 0,91 a $1,19 \%$ do peso corpóreo por mês de tratamento.

Embora os depoimentos das mulheres aqui estudadas refiram ser a quimioterapia e a ansiedade dela decorrente a justificativa central para o aumento do peso corporal, a literatura aponta ser o ganho ponderal pós-quimioterapia proveniente de diferentes causas, conforme assinalado anteriormente.

Para o grupo estudado, a expectativa de vir a submeter-se novamente a esta terapia antineoplásica acentuou a ansiedade frente à possibilidade de lidar com as alterações orgânicas e corporais indesejáveis, tais como registrados na literatura científica e já vivenciados, em parte, por elas: alopecia, enfraquecimento das unhas, náuseas, vômitos, diarréia, ressecamento vaginal e da pele, fadiga, anorexia, redução dos glóbulos brancos, plaquetas e o ganho de peso corpóreo, dependendo do tipo de droga utilizada no tratamento e de sua duração (BONASSA, 2005; CANTINELLI et al., 2006; McPHAIL; WILSON, 2000).

Diante do exposto, torna-se possível considerar que mulheres em quimioterapia adjuvante por câncer de mama tendem a ganhar peso sendo, este efeito colateral, altamente preocupante e indesejável para aquelas que já terminaram seu tratamento quimioterápico, a exemplo do grupo aqui estudado, pelo fato deste efeito gerar medo e ansiedade ao afetar sua imagem corporal (GIGLIO, 2004; MELO; ARAÚJO; OLIVEIRA; ALMEIDA, 2002).

Estes aspectos foram identificados nos discursos das mulheres aqui estudadas, pois as conseqüências do ganho ponderal pós-quimioterapia foram assinaladas por elas como uma das causas de sua insatisfação com a aparência do corpo, sendo um 
obstáculo para o vestir. As mulheres, ao perceberem-se com sobrepeso corpóreo, referiram estar gordas identificando sentimentos de inadequação com a imagem corporal especialmente quando suas roupas passaram a evidenciar para si e para os outros o ganho de peso, o que as deixou incomodadas:

\footnotetext{
“Fiquei muito mais gorda, não tem uma roupa e uniforme meu que me sirva."

“... tudo me incomoda... O calor me incomoda, o sol me incomoda, a roupa me incomoda..."

“Ah, eu tenho... a roupa fica apertada, eu engordei...”

"Para nós não tem coisa pior do que ter um guarda-roupa cheio de roupa que não te serve..." (G1).

“Eu olho para o corpo, né... assim, eu engordei... eu fui perdendo toda a roupa, parece que está tudo agarrado... Eu estou sentindo, que está até marcando... engordei cinco quilos...” (G4).

“... eu tenho que emagrecer, eu vou emagrecer, eu engordei quase onze quilos... Vou vestir, roupa nenhuma me serve, fico desesperada...” (G2).
}

Estes discursos coincidem com o que Ferreira (1999) afirmou em seu estudo sobre representações do corpo feminino pós-mastectomia: que tanto a cirurgia por câncer mamário como suas outras terapêuticas (neste caso a quimioterapia) acarretam efeitos que sinalizam às mulheres elementos significativos de um corpo que vivencia um mal-estar provocando mudanças nos mapeamentos da mente e do próprio corpo. As estratégias adotadas pelas mulheres, quando do retorno do hospital para casa, consistiu no uso de roupas largas e estampadas, também de adaptações na região do tórax como forma de melhorar a aparência pessoal ocultando a mutilação pós-mastectomia.

Neste estudo, as mulheres assinalaram que, ao sentirem-se expostas no convívio com os outros, buscaram adaptar o sutiã e roupas para disfarçar as mamas assimétricas.

Embora tais adaptações tenham resultado na melhora de sua aparência física e estado emocional facilitando o seu estar no mundo, observamos que estas adaptações, utilizadas por elas, parecem mais fáceis de terem sido adotadas em seu vestuário. Tais adaptações para as mamas, ocultas sob as vestes, não se tornam problema para as mulheres, visto não serem aparentes. Ao contrário do aumento do peso corporal, que muitas vezes não pode ser disfarçado dependendo do ganho ponderal adquirido.

Os depoimentos abaixo mostraram algumas estratégias que as mulheres estudadas adotaram para lidar com sua insatisfação perante o aumento do peso corporal: 
"Eu gosto de me arrumar, só não... Às vezes, não gosto de olhar no espelho... Não gosto de olhar no espelho... para não ver... Porque eu estou muito gorda..."

"Às vezes, eu não gosto de ver... o corpo... aí eu vou no banheiro, né, porque o espelho lá é mais...(menor) Vejo só o rosto...” (G2).

Ferreira (1999), ao explanar sobre a identificação do corpo mutilado por mulheres com câncer de mama, afirma que esta identificação efetiva-se pela percepção que as mulheres têm de seu corpo atual, alterado e diferente, que se torna mais evidente nas situações em que o observa, a exemplo dos momentos em que se vêem no espelho e quando estão despidas. A partir desta percepção, as mulheres evidenciam atributos que tornam seus corpos diferentes de outros, menos desejáveis, incomuns e inadequados que as colocam em situação de desvantagem social.

No presente estudo, os discursos das mulheres, acima apresentados, traduzem problemática semelhante, entretanto acentuam suas percepções sobre a imagem corporal distorcida e buscam não se defrontar com a realidade.

Uma das estratégias que denunciam tal situação foi a opção por observarem-se em espelhos que as possibilitavam somente mirar o rosto, mas não seus corpos, percebidos por elas como geradores de insatisfação com a aparência pessoal, devido ao ganho ponderal pós-quimioterapia. Fazendo-as lembrar, nesse sentido, de portarem alterações físicas decorrentes de um dos tratamentos do câncer de mama: a quimioterapia e seus efeitos adversos.

A presença próxima de indivíduos normais, para o sujeito estigmatizado, pode vir a reforçar as diferenças percebidas por este, forçando-o a uma revisão de seus atributos estigmatizantes que são confirmados quando este está diante de um espelho, levando-o à depreciação de si. Diante da confirmação da existência daquilo que considera como sendo seu defeito, são gerados sentimentos de insegurança no indivíduo estigmatizado quando ele aventa possibilidades sobre a maneira como os normais o receberão (GOFFMAN, 1988).

Diante do exposto acima, consideramos oportuno proceder a alguns questionamentos, no que se refere ao aumento do peso corpóreo das mulheres estudadas: a insatisfação para com a aparência do corpo, nessas mulheres, dá-se em relação a padrões culturais pré-estabelecidos? A estes padrões estão associados ideais de beleza e de saúde? 
$\mathrm{Na}$ sociedade ocidental, o corpo feminino tem sido alvo de exploração pela mídia de entretenimento, pela indústria cosmética, da moda e da cirurgia plástica que impõem rígidos padrões estéticos para as mulheres. Não corresponder a estes padrões as tornam, em certa medida, insatisfeitas com a imagem corporal (WOLF, 1992).

$\mathrm{Na}$ tentativa de alcançarem este padrão estético, as mulheres buscam dietas para emagrecimento (entre outras estratégias), sendo que muitas delas desenvolvem extrema insatisfação com o próprio corpo. Na sociedade atual, uma cintura fina representa potencial reprodutivo sendo ainda considerado bom indicador de saúde. Em contrapartida, a presença de gordura abdominal pode representar, para ambos os sexos, riscos de ataque cardíaco, diabetes, hipertensão e outros agravos à saúde (ETCOFF, 1999).

Os efeitos do aumento do peso corporal configuraram, neste estudo, parte das inquietações vividas pelas mulheres com câncer de mama, comprometendo sua imagem corporal causando-lhes insatisfação com a aparência pessoal. Especialmente quando associaram o sobrepeso à quimioterapia, o que as fazem permanecer em contato com a idéia incômoda de terem tido um câncer mamário. Entretanto, chama a atenção que ao assumirem tal insatisfação e apontarem estratégias para o emagrecimento, as mulheres estudadas reconheceram não adotá-las.

Os seguintes depoimentos mostraram que, frente ao aumento do peso corpóreo, elas se sentem inadequadas, pois suas roupas não se ajustam à nova forma do corpo. As depoentes reconheceram na dieta alimentar e nas atividades físicas as possibilidades de reduzirem seu peso corporal, embora justifiquem que os regimes de emagrecimento por elas adotados as fazem passar mal impossibilitando, nesse sentido, sua continuidade. Como não conseguem sucesso com as dietas adotadas, utilizam como estratégia comprar roupas maiores, o que vêem como a única solução possível para sentirem-se mais adequadas quanto à aparência pessoal:

"Não, o que me chamou mais a atenção foi... eu olho para mim, eu estou muito gorda, né... então... Aí eu começo fazer um regime... Aí dá um problema na minha cabeça... Aí minha cabeça muda” (gira as mãos em torno da cabeça).

“Ah... eu estou pensando em tomar um chá ...Tem que se conformar, né...Porquêo regime, às vezes, não pode fazer. E tomar remédio (para emagrecer) também não pode, né..."

“... fazer regime, a minha médica falou que pode... de bobeiras, né... Você está com fome, come couve... Você está com fome, bebe suco de couve... Pega a 
beterraba, rala a beterraba... Por que você vai comer pão, por que você vai comer macarrão? A minha médica falou tudo isso para mim... ela falou, eu não faço tudo isso... Ela me fala, 'pode fazer regime', não pode refrigerante, 'por que beber refrigerante?' Ela falou para mim... Ah, eu gosto de suco...suco de laranja, põe água, não põe açúcar...Quer tomar leite, tem que ser do desnatado, desnatado...não põe açúcar... Então, dá para emagrecer, só que a gente não faz...”

"Na minha família todo mundo era.... as mulheres da minha família todas eram... um corpinho lindo...Fez quarenta anos, virou uma porca, não vou, não, eu não quero virar...gorda desse jeito, então...é, é fazer isso...também para...para não engordar, fazer um pouco mais de exercícios...caminhada, mas não faço...Mas eu acho que exercícios ajudam...ajudam...”

"Eu fico desesperada. Depois vai pegar uma roupa, não serve, né... Você não pode comprar... Para mim, né, é difícil.” (G2).

“... já comprei roupas de três tamanhos.” (G1).

"Uso calça de elástico, tudo de elástico... Eu não quero comprar roupa grande, porquê eu vejo uma calça deste tamanho (mede com as mãos), eu fico agoniada." (G2).

O incômodo com a aparência do corpo gerado pelo aumento do peso corporal pós-quimioterapia levou as mulheres a estabelecerem comparações com períodos vividos anteriormente ao câncer de mama:

\footnotetext{
“Eu... Antes da cirurgia eu era mais magra, né...” (G2).

“... eu tinha cinqüenta e oito quilos... sempre... digo assim... gostei.. de cuidar do meu corpo, sempre fui... vaidosa, sabe... Quando estudava, na escola, no uniforme, tudo... aquele uniforme feio, branco, cinza, meia três quartos, aquele cinto vermelho, vocês lembram, né... E sapato colegial... aqueles concursos, lá, de miss Corpo, eu ganhei o concurso... juro. E de uniforme e tudo, foi, eu tinha cinturinha, tudo...Agora eu estou...estou gorda...”

“... eu gostaria de ser...de ter o meu corpo de antes... se voltar está bom, né? Será que volta?...Deus queira." (G4).
}

As falas acima sinalizam para alterações da imagem corporal no grupo estudado, pós-tratamento por câncer mamário. Este grupo, ao ter em mente uma imagem idealizada sobre o próprio corpo, sendo rememorada por experiências prazerosas, ao confrontar tal imagem à concretude de um corpo radicalmente modificado pelo tratamento da doença, tem frustrada sua expectativa sobre o corpo atual, por distanciar-se da imagem idealmente elaborada.

Esta situação acaba por gerar às mulheres sentimentos de inadequação e insatisfação com a aparência pessoal, desmotivando-as para o enfrentamento do sobrepeso corporal. 
Seus discursos assinalaram o desejo de retornarem a uma imagem de corpo correspondente aos padrões estéticos corporais valorizados em nossa sociedade atual e, de certa forma, assimilados por elas: um corpo evidenciando magreza, cintura reduzida e também saúde, uma vez que antes de serem acometidas pelo câncer possuíam estes atributos.

Entretanto, ao depositarem esperanças em uma instância exterior a elas (Deus) para a recuperação da imagem corporal perdida, ao assumirem não adotar as estratégias para a redução de peso (exercícios físicos e dieta) e comprar roupas largas e elásticas para vestir, parecem evidenciar suas dificuldades de fazer o enfrentamento do sobrepeso.

Uma possível explicação para as dificuldades de enfrentamento do sobrepeso a que as mulheres estudadas apresentaram estaria associada aos sintomas da fadiga, sendo esta um dos efeitos colaterais da quimioterapia e do tratamento cirúrgico por câncer de mama (ISHIKAWA; DERCHAIN; THULER, 2005).

O cansaço e indisposição física decorrente da fadiga podem justificar a desmotivação das mulheres para a prática de atividades físicas. Estes sintomas, associados ao aumento da ingesta alimentar, proveniente da ansiedade advinda do estresse associado à cirurgia e à quimioterapia, podem atuar combinadamente para o ganho ponderal, constituindo barreiras para seu enfrentamento.

Estas explicações, sobre os efeitos indesejáveis do tratamento quimioterápico para o câncer de mama, baseadas em uma perspectiva médica e biologicista podem justificar o sobrepeso corpóreo no grupo estudado. Embora outras possibilidades possam ser consideradas para justificar as causas motivacionais que impediriam estas mulheres de retornarem a seu peso corporal original desejado, sendo, estas últimas, baseadas em uma perspectiva sociocultural.

Desde sua origem, o câncer tem sido culturalmente associado à morte embora os progressos mais recentes das ciências médicas ofereçam aos pacientes maior sobrevida, especialmente para os casos de determinados tipos de câncer, quando detectados precocemente. Em estágios avançados, a doença pode representar sofrimento intenso, que transparece no estado físico de seus portadores trazendo-lhes severas modificações corporais, tais como fraqueza e emagrecimento que podem levá-los à morte. 
A literatura apresenta evidências de que a perda de peso involuntária é um dos sinais precoces do câncer que se não tratada precocemente pode causar aos pacientes problemas nutricionais de diversas ordens, como caquexia, anorexia, redução da massa muscular e da funcionalidade, também complicações cardio-respiratórias entre outras (CORREIA, 2005).

Acresce-se a isso que as representações culturais do câncer o apontam como uma doença associada à destruição da vitalidade, transformando o ato de comer em um sacrifício, ainda degenerando os tecidos do corpo. Entre as repercussões negativas para com o corpo de um paciente em tratamento por câncer, estão a perda de peso e do apetite. As causas multifatoriais da doença contribuem para estruturar a crença de que a mesma tem origens obscuras e terapêutica ineficaz, podendo representar contaminação, falta de energia, fraqueza e decadência, entre outras conotações pejorativas (SONTAG, 2002).

Ao pensarmos o câncer como uma doença que representa a degeneração orgânica e corporal de seus portadores, torna-se possível compreender, enquanto uma possibilidade, que o emagrecimento pode evidenciar os aspectos deteriorados aparentes de um portador de câncer em estágio agravado. No caso das mulheres estudadas, mesmo sendo algo desejado, a perda de peso pode vir a representar, para elas, que o corpo padece de algum mal, tornando-as relutantes a adotar estratégias que as capacitem perder peso, mesmo que o sobrepeso as torne vulneráveis aos olhares dos outros.

Nesse sentido, a "opção" pela manutenção do sobrepeso corporal (por meio de exageros alimentares e não incorporação de estratégias para seu enfrentamento) pode ser preferível à sua redução, visto que culturalmente o emagrecimento de um paciente com câncer pode vir a representar sua debilidade e morte. Este aspecto transparece no depoimento abaixo:

“Ficar sem comer... De jeito nenhum. É a única coisa boa que eu tenho...Não é? Passar fome, não é comigo...Amanhã eu morro, então...Tive uma irmã, eu tive o problema (o câncer de mama) antes dela..Ela ficou sem comer...Ela morreu.." $(G 2)$.

Há que se considerar ainda que em um passado recente, a gordura corporal foi representativa de indivíduos aparentemente saudáveis e aptos para o trabalho, 
independentemente do gênero. Embora atualmente a ciência afirme o contrário, estes valores ainda são reproduzidos por indivíduos de diferentes classes sociais.

Muraro e Boff (2002), ao reportarem-se às diferentes valorações conferidas à aparência do corpo nas classes burguesa e trabalhadora, afirmam que para a primeira o corpo era (e ainda o é) considerado fonte de prazer, poder e consumo. Para a classe trabalhadora, o corpo é objeto de exploração no trabalho devendo evidenciar aspectos que o caracterizem como aptos para as tarefas laborativas, como força e vigor sendo, a gordura corporal, um dos sinais representativos de aptidão física.

Um estudo sobre indivíduos pertencentes às classes burguesas e do campesinato aponta que as mulheres, oriundas desta última classe, quando indagadas sobre seus corpos, não se referiam à beleza, porém à força representada pela gordura corpórea. Estas mulheres apreciavam-se mais quando eram "gordas e fortes" (e não "magras e fracas"), pois, desse modo, consideravam-se aptas para o trabalho nos campos, embora o estudo aponte que esta crença atuava no sentido de fabricar corpos oprimidos, ou seja: aqueles que serviriam somente para a superexploração das mulheres no trabalho visando o sustento da classe burguesa (MURARO; BOFF, 2002).

Os valores expostos acima são algo que se deva tomar em conta, pois, reproduzidos ao longo da história e introjetados pelos indivíduos, acabam por justificar a associação inadequada de um corpo saudável e forte à gordura, e de um corpo doente e fraco à magreza. Essa representação poderia levar as mulheres aqui estudadas a preferirem manter o sobrepeso corpóreo, mesmo a contragosto, para evidenciar um suposto controle sobre seu estado de saúde, a mostrar o corpo aparentemente "fragilizado" ou "debilitado" pela redução de seu peso e, nesse sentido, fazendo-o aparentar sintomas de doença (nesse caso, o câncer de mama).

Diante do que foi apresentado, torna-se possível afirmar que o câncer de mama feminino, ao acometer a base biológica e física das mulheres (o corpo) faz incidir sobre esta mesma base os valores culturais forjados na sociedade a que pertencem estas mulheres (valores sobre como se deve aparentar o belo, o saudável, o perfeito).

Suscetíveis às exigências de seu mundo circundante e, tendo introjetado tais valores, as mulheres podem vir a buscar corresponder aos mesmos e, não o conseguindo, podem ter acentuado seu sofrimento físico e emocional.

Nesse sentido, vale citar Rodrigues (1986, p. 130), ao afirmar que: 
No corpo, a ordem fisiológica material se une à ordem ideológica moral, como signos nos quais se encontram e se reúnem o sensível e o inteligível, o significante e o significado. Os fenômenos e processos fisiológicos se erigem em significantes, cujos significados são fenômenos e processos sociológicos.

Alterações na aparência corporal de um indivíduo provocadas por doença, deficiência ou mutilação acarretam em sentimentos de incômodo e estranheza ao próprio indivíduo e aos outros. Estes últimos, ao se considerarem pertencentes à categoria dos indivíduos "normais", expõem-se à ameaça concretizada no corpo do portador da deficiência. Este, por sua vez, acaba por representar uma ferida narcísica daqueles que o vêem, ao mostrar “... um conflito não camuflável, não escamoteável, explícito em cada dinâmica de inter-relações” (AMARAL, 1991, p.191).

As mulheres estudadas, ao deixarem de corresponder aos ditames socioculturais valorizados para com sua aparência física verbalizaram insatisfação com a imagem corporal pós-tratamento cirúrgico e quimioterápico por câncer mamário. A constatação de portarem mamas assimétricas (em decorrência da cirurgia conservadora) e estarem com sobrepeso corporal (em virtude da quimioterapia e ingesta alimentar elevada) foi por elas identificado como algo incômodo no que se refere à aparência pessoal.

Apesar de verbalizarem esta insatisfação com clareza, não adotam estratégias efetivas para a redução do peso corporal, pois, se na sociedade atual um corpo magro tornou-se um ideal de beleza e de funcionalidade, no contexto da saúde a perda de peso é representativa de degeneração corporal e ameaça à vida, sendo, inclusive, um dos sintomas característicos do câncer, como apontado por Sontag (2002).

Estas mulheres também verbalizaram sentimentos de inadequação e constrangimento, em decorrência de alterações dermatológicas (alopecia, alterações nas unhas e mudanças no odor corporal) provocadas pela quimioterapia. Referiram sentirse incomodadas e expostas aos outros, identificando sentimentos de tristeza e vergonha diante da perda dos cabelos, mesmo quando optaram por cortá-los:

\footnotetext{
"Bom no meu caso não chegou a impedir, mas constranger, sim... impedir não... Eu fiz quatro quimio antes.. então eles já sabiam que eu não estava bem, mas é horrivel, ficar sem cabelo... foi constrangedor... constrange... O povo já saca, que você está debilitada..." (G4).

"O que me incomoda é... a careca." (G1).
} 
“...ia tomar banho, lavava o cabelo, você não sabia como penteava, porque passava a escova começava a sair tudo, não tinha como... Você passava (a escova), aquilo enchia a escova...”

“Ah, eu fiquei desesperada, sábado, né... sexta à noite, que... né... já... amanheceu no sábado, eu fui pentear o cabelo, começou a cair... caía... fazia 'assim', aquele monte na mão... o meu quarto ficou cheinho de cabelo... aí eu fiquei desesperada, eu chorei muito... falei assim, falei para o meu marido, 'ai, eu vou sair, vou dar uma volta, já volto'... Eu entrei na catedral e fui... rezar o terço, lá eu chorei bastante, ai meu Deus... Eu peguei, saí da catedral e fui... cortei o cabelo, num salãozinho lá perto, uma portinha... aí cortei lá, curtinho, né, mas... fiquei muito chateada, nossa, que vergonha das outras... dos fregueses, eu cheguei, o bar estava assim, de sábado, né... estava lotado, falei, 'ah, cortei o cabelo, precisei cortar'... e já fui entrando...” (G4).

Os cabelos compridos podem representar atitudes, afiliações, gosto, sexo, idade e outras características informativas de uma pessoa, sendo considerado, ainda, um registro do corpo durante determinados períodos da vida de um indivíduo traduzindo sinais daquilo que ele come, dos remédios que utiliza provendo um registro de como a saúde deste indivíduo se apresenta (ETCOFF, 1999).

Ao longo da idade, os cabelos tendem a reduzir-se, devido a fatores hereditários, hormonais e emocionais, mas a redução ou perda dos cabelos, antecipada pela quimioterapia por câncer de mama, foi vivenciado pelas mulheres aqui estudadas como uma situação drástica e constrangedora, ao tornar visível para o mundo seu estado de saúde debilitado, também interferindo em sua imagem corporal.

Em pacientes com câncer, a perda dos cabelos decorrentes do tratamento quimioterápico produz modificações na imagem corporal, ameaçando a identidade e tornando-se foco de preocupação ante o temor de uma rejeição social (SILVA, 2005).

Nesse sentido, a imagem corporal de mulheres com câncer de mama sofre alterações severas pela própria cirurgia mutiladora, mas também pela quimioterapia que, ao provocar alopecia denuncia a problemática da doença vivida pelas mulheres aos outros (FERREIRA, 1999).

Embora o impacto dos efeitos devastadores da cirurgia e da quimioterapia tenha sido avaliado diferentemente pelas mulheres estudadas por Ferreira (1999), ambas as formas de tratamento lhes acentuaram a percepção de terem sofrido perdas na imagem corporal.

Nesse sentido, a mulher com câncer de mama passa por várias perdas ao longo da experiência da doença. Essas perdas iniciam-se com a possibilidade de pensar em ter um câncer, acentuam-se com a confirmação do diagnóstico da doença e seguem-se com 
a cirurgia e com outras terapias antineoplásicas causadoras de severas mudanças em sua imagem corporal, haja vista seus efeitos colaterais (MALUF; MORI; BARROS, 2005).

Estes sentimentos de perda que passam mulheres com câncer mamário são originados da intimidade corporal atingida pelos tratamentos, trazendo-lhes repercussões físicas, sociais e psicológicas. O espaço corporal representa a história e os conflitos de cada mulher, também sua estrutura emocional e social e, ao ser ameaçado por agentes agressivos põe em risco as condições de equilíbrio dessas mulheres (SILVA; MAMEDE, 1998).

Neste estudo, diante da percepção negativa dos efeitos colaterais da quimioterapia na imagem corporal, as mulheres apontaram ser outra pessoa, não se reconhecendo mais como eram antes deste tratamento. Seus discursos expressaram as mudanças por elas sofridas na estrutura das unhas, no odor corporal e nos cabelos que nasceram diferentes do que eram anteriormente à quimioterapia:

\footnotetext{
"As minhas unhas ficaram roxas, da mão e do pé, eu coloquei esmalte, ficou horrivel."

"Eu acho que o meu cheiro mudou com a quimioterapia, aquilo acabou comigo... Meu cheiro é outro, meu organismo é outro... Eu ... eu sou outra pessoa.” (G1).

"Ah... foi meu cabelo que nasceu enrolado...eu não gostei..não...agora...faz escova, chapinha para...para alisar um pouco, porque está muito enrolado...não era enrolado...eu não gostei do meu cabelo...Aí, minha sogra fala assim ' ...você reclamava de amarrar o lenço, né, então agora está bom assim, não precisa reclamar'...sabe, eu não gosto do meu cabelo enrolado." (G4).
}

Nas falas acima, as mulheres denotam alterações na imagem corporal ao não se reconhecerem, na atualidade, à semelhança da imagem de corpo introjetada anteriormente à doença, em termos de aparência física. Os aspectos funcionais também foram indicativos de alterações da imagem corporal, neste grupo, visto deixarem de corresponder às expectativas de desempenho de atividades, sendo, estas alterações, representadas pelo linfedema do braço.

O temor do linfedema figurou entre as preocupações mais angustiantes apresentadas pelas mulheres estudadas, fazendo-as refletir sobre suas reais possibilidades de continuarem a realizar determinadas atividades, conforme apontam suas falas: 
"A gente quer fazer... mas tem medo pensando no corpo, né..." (G3).

"O braço, eu fico preocupada com o braço, de tirar a defesa da gente".

“... agora tem que ter aquela preocupação com a parte do corpo... com o braço... com a mão...” (G1).

Panobianco (2002) aponta que mulheres com câncer mamário com linfedema de membro superior podem ter restrições em algumas de suas atividades, em decorrência das limitações físicas (dor, peso), levando-as a assumir sentimentos de tristeza e angústia frente às modificações na imagem corporal.

Neste estudo, os discursos do grupo, acima apresentados, denotam seu medo e preocupação significativa frente à possibilidade de vir a adquirir o linfedema ou mesmo agravá-lo. Para Almeida et al. (2001), assim como a perda da mama, a possibilidade do linfedema configura como objeto de preocupação para mulheres com câncer mamário, pois sua visibilidade representa sequiela da doença, assinalando, ainda, restrições e limitações no desempenho de atividades dessas mulheres.

As mudanças na imagem corporal de uma pessoa englobam diferentes formas pelas quais ela experiencia e conceitua seu próprio corpo. A imagem corporal deve ser compreendida como um fenômeno singular e, por estruturar-se no contexto da experiência existencial e individual do ser humano, a inter-relação entre imagens corporais leva a uma maior ou menor valorização e interesse dos indivíduos em determinadas partes dos seus próprios corpos. E, destes, para com os de outros indivíduos, levando a uma associação entre a imagem que o sujeito tem de si e dos outros (SCHILDER, 1981; TAVARES, 2003).

Para Shearsmith (2001), qualquer doença que ameace a integridade do corpo humano acarreta ao sujeito mudanças físicas, psicológicas e sociais alterando sua imagem corporal. A aparência do corpo, as crenças a ele atribuídas acerca da presença de limitações e sobre como o sujeito interage com o mundo a partir dessas alterações podem vir a acentuar as mudanças percebidas, temporária ou permanentemente.

Nesse sentido, a imagem corporal da mulher é construída no transcorrer da vida e depende da condição socioeconômica, psico-espiritual e emocional da família, do meio social a que pertence e também da filosofia de vida adotada por ela. No processo de recuperação de uma doença desfigurante e ameaçante à vida, como um câncer de mama, assim como dos efeitos deletérios de seus tratamentos, as mulheres podem expressar insatisfação diante das mudanças percebidas levando-as a modificarem seu 
estilo de vida, situação que pode atuar negativamente no comportamento das mesmas, gerando sentimentos de desvalorização pessoal (SILVA; MAMEDE, 1998).

Assim, diante dos discursos apresentados anteriormente, denota-se a autodesvalorização das mulheres estudadas, conseqüentes à mudança na imagem corporal, ao referirem ser outras pessoas, sentirem-se inadequadas quanto à aparência das unhas e dos cabelos estruturalmente modificados pós-quimioterapia e também à presença do linfedema como algo problemático à aparência e à funcionalidade do corpo.

Ressaltamos que o processo de reelaboração da imagem corporal, para a mulher tratada por câncer mamário, necessitará de tempo para ser efetivada, sendo dependente de diversas variáveis (FERREIRA; MAMEDE, 2003; HARTCOURT; RUMSEY, 2001; SILVA; MAMEDE, 1998).

Diante do que foi exposto nesta unidade temática, as mulheres operadas por câncer mamário podem perceber-se em situação de desvantagem social quando sua aparência física e funcionalidade deixa-lhes, em certa medida, incertas diante da constatação de portarem corpos com atributos diferentes daqueles idealmente concebidos e valorizados na sociedade.

Embora se reconheça a atuação feminista no sentido de desestruturar a hegemonia masculina de controle das mulheres em diversas situações e papéis sociais exercidos por elas, há que se considerar que os atributos valorizados para com a aparência física dos corpos femininos foram construídos e sancionados em uma perspectiva cultural androcêntrica predominante por séculos.

Wolf (1992), ao explanar sobre a extrema valorização conferida à aparência física do corpo feminino nas sociedades ocidentais, defende esta valorização como resultante de manipulações políticas e culturais elaboradas na sociedade patriarcal para o controle das mulheres na sociedade. Na medida em que as mulheres se firmaram em espaços tidos como masculinos, seja na internalidade dos sistemas educacionais ou do trabalho, passaram a confrontar-se com novos desafios para mantê-las ainda sob o jugo masculino: o de corresponderem a conceitos e imagens ideais de beleza femininos, amplamente divulgados pelos veículos de comunicação de massa sendo, tais estratégias, consolidadas especialmente na década de 1980. 
Assim, novas formas de controle e submissão das mulheres aos valores e ideais androcêntricos lhes são apresentados por meio de diferentes áreas da mídia, a exemplo da indústria pornográfica e da cirurgia plástica estética. Esta tem sido considerada uma nova estratégia de coerção social às mulheres substituindo, de certo modo, as antigas formas até então utilizadas para exercer este domínio: os mitos da maternidade, domesticidade, castidade e passividade (WOLF, 1992).

Assim, nesta unidade temática, as alterações da imagem corporal nas mulheres estudadas, em decorrência do tratamento cirúrgico e quimioterápico por câncer mamário, sinalizaram às mesmas a percepção de um corpo imperfeito estética e funcionalmente por não corresponder ao ideal de corpo feminino valorizado em nossa sociedade, embora as limitações físicas e os aspectos funcionais do corpo tenham sido destacados na unidade temática que se segue.

\section{Corpo limitado}

O grupo estudado identificou, enquanto parte da problemática originada do tratamento por câncer de mama, que o corpo apresenta limitações e alterações físicas de diversas ordens. Ao perceberem seus corpos fisicamente cansados e com dor, entre outras alterações, as mulheres passaram a perceber-se preocupadas e limitadas ante o desempenho de algumas de suas atividades.

Seus discursos mostraram que, após a cirurgia e a quimioterapia, passaram a sentir indisposição física e cansaço, assim como dor em determinadas partes do corpo:

\footnotetext{
“... não sei se é... realmente da cirurgia ou se é... da nossa mente, porque eu vejo que a maioria reclama de indisposição... para tudo... indisposta, indisposta, indisposta... cansada, cansada... eu não sei, eu... acho que... eu vi muitas, muitas mulheres reclamando, sabe, muito 'cansadas'...fisicamente cansadas...agora, cansada, eu não sei o que é...”

“... eu só sinto canseira, então, agora, também depois da cirurgia piorou... Eu sinto mais canseira, mais dor nas pernas gosto de ficar mais deitada... é, deitada, depois eu trabalho sem parar, também... Eu sinto muita canseira, mas não é só depois da cirurgia... mas aumentou... aumentou mais a canseira... depois da cirurgia."

“... mas eu acho que é psicológico, é mental, eu não sei... eu não sei... e eu saio bastante, até... eu saio cansada...” (G4).
} 
De acordo com os discursos expostos, as mulheres têm dúvidas acerca da gênese de sua indisposição física e dor, sendo que tais dúvidas se traduziram em questionamentos sobre a possibilidade destes sinais e sintomas terem-se originado da cirurgia ou de causas psicológicas desconhecidas.

No grupo estudado, o desconhecimento sobre a causalidade dos sinais e sintomas provocados no corpo pelos diferentes tratamentos por câncer de mama, como evidenciado nestes depoimentos, pode atuar fazendo com que as mulheres percebam sua doença como gerada por causas incertas e insidiosas, reiterando o que Sontag (2002) considera representar, metaforicamente, um câncer: uma doença com causas obscuras e terapêutica incerta, que gera nas pessoas uma diversidade de significações.

O cansaço, a indisposição física e as dores apontadas pelas depoentes associamse a sintomas de fadiga provocada pelo câncer de mama e seus diferentes tratamentos.

Segundo Bonassa (2005), a fadiga, em pacientes com câncer, é percebida por persistente e subjetiva sensação de cansaço, associado à doença e a seu tratamento, sendo acompanhada por sintomas como redução de energia, exaustão, dor, fraqueza, lentidão e perda de concentração, memória sendo, ainda, responsável pela perda de interesse do paciente em suas atividades. Estes aspectos emergiram das falas das mulheres estudadas, ao apontarem indisposição física e cansaço, também dor nas pernas levando-as a preferir ficar deitadas ou, em contrapartida, enfrentarem diferentes situações do dia a dia, mesmo cansadas (sair de casa, trabalhar, embora indispostas).

A fadiga é um sintoma freqüentemente presente em pacientes com câncer e sua gênese precede ou acompanha o diagnóstico da doença, afetando de $70 \%$ a $100 \%$ daqueles que realizam quimioterapia e/ ou radioterapia, sendo altamente prevalente e raramente tratada A fadiga decorrente do câncer apresenta variações em sua intensidade, sendo estas influenciadas pelas características dos pacientes, da doença e do tratamento por eles recebido (BONASSA, 2005).

Mulheres com câncer de mama submetidas à quimioterapia e à radioterapia apresentam maior probabilidade de desenvolverem fadiga durante e após o término destas terapias antineoplásicas, embora a forma pela qual estes tratamentos causam fadiga não seja totalmente clara (ISHIKAWA; DERCHAIN; THULER, 2005).

Embora a natureza da fadiga seja parcialmente obscura, seus sintomas interferem negativamente na vida de pacientes com câncer (incluindo-se o da mama), 
modificando-lhes o desempenho de atividades, ou mesmo incapacitando-os. Assim, torna-se importante e necessário que profissionais da saúde avaliem as repercussões da fadiga no desempenho das atividades diárias destes pacientes (BONASSA, 2005; ISHIKAWA; DERCHAIN; THULER, 2005; SCHNEIDER; LOPES; FURTADO, 2004).

Além das limitações físicas advindas da fadiga, as mulheres estudadas também representaram seus corpos limitados por redução na amplitude de movimentos, dores nos braços, na incisão cicatricial e couro cabeludo; assim como alterações na região das mamas e braços como formigamento, adormecimento, prurido, inchaço e elevação da temperatura. Seus discursos apontaram para a existência destas limitações e alterações físicas no período pós-operatório imediato. Para algumas delas, tais sinais e sintomas perduraram ou atualmente inexistem:

“... tipo um trauma, mesmo, viu? Nossa, me encolheu os nervos, no começo, eu não esticava o braço...”

“... eu tive muita dor... No braço, eu tive muita dor..."

"Eu dava graças a Deus quando a enfermeira me dava profenid para me aliviar a dor... Como eu tinha dor no braço...”

"Não tive nada,... Até hoje... hoje dói o corte...quer dizer, o quelóide, que chama...Era estreito e ele abriu um pouco...mas...Ele coça...” (G2).

"Mas ela (a mama) está mais inchada, inchada, dolorida e... fica quente...Então, minha filha queria me levar até na emergência, ontem... Que estava quente, inchada, incomoda...” (G3).

"Eu sentia dor... queimava aqui as costas... não era sempre, não, era assim, coisa de cinco minutos, às vezes à noite... sentia aquele queimor nas costas... meu braço ficava dormindo eu acordava com o braço formigando, meu braço adormecia e queimava também... Eu tinha muita dor... antes ... hoje, acabou tudo isso...”

"Eu fico pensando, será que não vai passar, porquê eu fiquei assim também, e passou, né...”

"Na sexta -feira, eu prendi o dia inteiro o cabelo, né... mas à noite, e eu ... doeu demais o meu couro cabeludo... eu falei assim para o meu marido 'nossa, eи não agüento de dor no meu couro cabeludo', deitei a cabeça, assim, no travesseiro, $e$ falei 'Nossa, por que será... como está doendo o meu couro cabeludo'... né... aí... quando foi no outro dia, de manhã.. foi demais... Estava dolorido o meu couro cabeludo..."

"Fica... fica dolorido (o couro cabeludo)... mas eu, quando começou a cair... eu puxava para trás, para cair por aqui. já que é para cair, cai de uma vez... aí... o que ficou, eu passei a gilete, logo, duas vezes ele caiu... a primeira, na quimio, e depois da cirurgia, né... antes de depois...” (G4).

A presença destas alterações físicas no corpo das mulheres estudadas foi avaliada por elas como traumáticas e limitantes para a realização de suas atividades, 
fazendo-as lembrar constantemente de portarem disfunções e alterações corporais decorrentes do tratamento do câncer mamário levando-as a compararem-se consigo mesmas, anteriormente à doença, quando tais alterações inexistiam:

“... pelo menos, por enquanto, eu tenho muita limitação... porque eu era uma pessoa muito ativa, né... Então, hoje tenho muita limitação. Eu me esforço, eu faço, mas não com aquela disposição que eu tinha antes.” (G1).

Além da indisposição física decorrente de fadiga, a presença de dor e outras limitações, referidas pelas mulheres, pode interferir negativamente em sua imagem corporal. Limitações físicas podem fomentar senso de incapacidade, especialmente ao tornarem-nas dependentes de outras pessoas para a realização de suas atividades, incluindo-se o cuidado próprio (FERNADES, 1997).

A presença de limitações e alterações físicas em pacientes com câncer mamário tais como dor, acompanhada ou não de formigamento, latejamento, queimor e choques na região do órgão amputado e outros espaços do corpo, a exemplo do que foi constatado pelas mulheres aqui estudadas, podem decorrer de diferentes fatores.

Estes sinais e sintomas podem advir do tumor primário, de iatrogenias resultantes das intervenções terapêuticas ou dos procedimentos de investigação, também de condições não relacionadas à doença oncológica. São freqüentes a presença dores incisionais e cicatriciais pós-amputação das mamas, na fase aguda, decorrente de processo inflamatório e, na fase crônica, em virtude de recidiva ou secção de nervos periféricos quando da realização de cirurgia. A ação de quimioterápicos também pode originar neuropatias, a exemplo de polineuropatias periféricas, acompanhadas ou não por mialgias e artralgias (CAPONERO; VIEIRA; TEIXEIRA, 2004).

No estudo de Ferreira (1999), as mulheres com câncer mamário identificaram dor, limitação e outras alterações físicas como sendo limitantes à realização de suas atividades diárias, frustando-lhes a expectativa de reassumirem seus papéis como dona 
de casa, mãe e esposa. O corpo passou a ser representado por elas como lócus de dor e limitações forçando-as a conviver com estes sinais em diferentes períodos, do pósoperatório imediato ao mais tardio.

Diante das limitações físicas e funcionais observadas pelas mulheres aqui estudadas, dúvidas surgiram, e suas falas trouxeram questionamentos sobre as reais necessidades de terem tido que realizar a cirurgia de retirada parcial ou total das mamas. Estes discursos também fizeram transparecer que, antes do câncer de mama, a vida para elas era idealizada como sendo melhor:

“Às vezes eu chego a pensar, que se eu não tivesse operado... se eu... se eu estaria
do mesmo jeito (com um corpo funcional)... mas, às vezes, eu ... estava tão
quieta... não dava... eu não sentia nada... não sentia nada, eu saía, eu era
despreocupada... agora, fez a cirurgia... dói debaixo do braço , dói o braço, a
gente fica, às vezes, pensando... assim, se não tivesse mexido, o câncer poderia
ter... intensificado, teria sido pior, porque os médicos sabem o que fazem...” (G4).

Ao afirmarem que o câncer de mama poderia ter agravado sua saúde e que os médicos souberam como proceder diante deste diagnóstico, as mulheres justificaram a necessidade da cirurgia que, mesmo lhes causando dor e limitações, ela e os demais tratamentos se tornaram uma necessidade central para o controle da doença. $\mathrm{O}$ depoimento acima reforça a percepção das mulheres de que o câncer poderia ter agravado caso não fosse tratado em tempo hábil embora, inicialmente, tenha se apresentado assintomático. Desse modo, as mulheres parecem aliviar-se emocionalmente das inquietações e dúvidas por elas assinaladas quanto à necessidade e natureza do tratamento a que foram submetidas.

Ao exporem suas dúvidas quanto à origem dos sinais e sintomas presentes no corpo pós-tratamento do câncer mamário, a exemplo de dor, cansaço e limitações, e ao questionarem sobre as reais necessidades dos procedimentos utilizados em seu tratamento (causadores de alterações na aparência pessoal e limitações físicas), as mulheres apontam em seus discursos que o câncer de mama obrigou-as a submeteremse a tratamentos agressivos e com possibilidades incertas de cura.

Assim, reconhecem o câncer mamário como inicialmente assintomático, o representando como sendo de natureza invasiva, agressiva e inesperada, a exemplo do discurso abaixo: 


\footnotetext{
"Meu marido falava assim 'você pensa que só acontece com os outros? Acontece com a gente também, sem esperar, em cima da hora'.” (G2).
}

As mulheres com câncer de mama, ao levantarem hipóteses acerca da origem da doença decorrente de uma condição orgânica interna, mostram em seus discursos uma indefinição do agente que desencadeia o processo mórbido deixando transparecer preocupações sobre a possibilidade de recidiva do tumor. Essa representação do câncer torna-se assustadora para estas mulheres, deixando-as temerosas ante as reflexões sobre a possibilidade de cura ou do retorno do câncer (ALMEIDA, 1997).

O câncer, ao ser simbolicamente comparado aos movimentos incertos de um caranguejo, também por ser este um animal de hábitos noturnos, pode vir a representar a possibilidade de invasão e descontrole da doença. Etimologicamente, a palavra câncer também deriva do grego karkinos e do latim cancer, ambos significando caranguejo. (ALMEIDA et al., 2001; MALUF; MORI; BARROS, 2005; SONTAG, 2002).

As mulheres estudadas, ao se assumirem portadoras de uma doença com as características acima assinaladas, que lhes acarretam mudanças na aparência do corpo e limitações físicas, identificaram sentimentos de impotência, fragilidade e revolta frente às mudanças corporais provocadas pela doença e seu tratamento.

\section{Fragilidade, revolta e conformismo}

O grupo estudado, frente à percepção do câncer mamário enquanto uma doença exigente de uma terapêutica agressiva e resolutividade incerta, causadora de alterações corporais aparentes e limitações físicas, assumiu sentimentos de desproteção, desesperança e necessidade de cuidado demonstrando fragilidade emocional:

“... desproteção, parece, né, 'ai'’! Alguém cuida de mim que eu não estou vendo nada, né...” (G1).

“... eu sinto muita tristeza, tem hora que eu choro...” (G4).

"Eu falo assim... parece que a gente está indefesa, né, a gente sente aquela carência, mas tem hora que a gente tem afeto dos parentes e tudo... mas a gente sente aquela carência de um afago.” (G1). 
As mulheres estudadas apresentaram sentimentos de angústia, tristeza e revolta, acentuados pela falta de informação quanto aos procedimentos cirúrgicos utilizados no tratamento do câncer mamário, levando-as a atribuírem à equipe de saúde a responsabilidade pela omissão destas informações.

O desconhecimento sobre a necessidade de realização de linfadenectomia axilar e sua repercussão para com seus corpos lhes causaram surpresa, frustrando as expectativas de ter o corpo melhor preservado após realização do tratamento cirúrgico:

\footnotetext{
"Eu acho que é um impacto muito grande e eu falo assim, que eu caí de gaiato nessa, eu não esperava que fosse assim, tanto... Eu não esperava que fossem esvaziar as axilas, não me avisaram... Nossa, eu fiquei baqueada foi, acho que foi isso... É uma coisa que eu não esperava, eu fiquei com muito medo... Eu vi todo mundo vindo me visitar, eu, nossa, eu chorava até...” (G2).

"Nossa, eu chorei tanto... Eu chorei bastante... meus filhos choraram, meu marido também... até meu marido chorou, nossa! Falei 'ai, eu pensei que fosse ficar só na biópsia', só naquilo, aí tem mais, fazer uma cirurgia maior, né... E vai ser, vai ter que tirar... fazer esvaziamento debaixo do braço... Sabe o que eu achei... Dizem que a medicina está mais avançada... que agora, eles tiram só...as células...que estão afetadas, mesmo, né...os gânglios..que estão afetados... Nossa, eu achei uma injustiça, tiraram vinte e quatro gânglios das minhas axilas...esvaziaram, né... Eu sou contra, eu fui contra isso, eu acho que foi muita coisa... me judiou muito... O caso maior foi tirar os gânglios...Que na cirurgia eu fiz o quadrante, nem parece...Até perguntaram se eu tinha feito plástica, se eu tinha feito reconstituição, falei 'não, de jeito nenhum'..." (G3).
}

As falas acima denotam as repercussões negativas da linfadenectomia axilar nas mulheres, situação por elas avaliadas como sendo tão impactantes quanto a cirurgia para retirada parcial das mamas, implicando em intenso sofrimento que as fizeram, inclusive, descartar a possibilidade de realizarem cirurgia de reconstrução mamária.

A maioria das mulheres desconhece seu tumor enquanto uma doença sistêmica. Desse modo, a cirurgia para retirada total ou parcial das mamas, muitas vezes, não consiste em tratamento único, sendo adotado um tratamento sistêmico, como a quimioterapia e também a linfadenectomia axilar, como no caso do grupo aqui estudado. Os efeitos das terapias adotadas pelas equipes de saúde, dependendo de sua extensão e seqüelas, pode gerar nas mulheres sentimentos de revolta e perda, em diferentes níveis de intensidade (MALUF; MORI; BARROS, 2005). 
Em decorrência da desinformação, as mulheres estudadas expressaram dúvidas quanto às técnicas cirúrgicas a que foram submetidas, também sentimentos de tristeza e revolta frente aos resultados desfigurantes e limitadores deste tratamento. Consideraram ainda que, se não tivessem tido que realizar a cirurgia por câncer de mama estariam em melhores condições físicas e emocionais e, nesse momento, parecem revelar desconhecimento acerca da gênese e real gravidade do câncer mamário:

\footnotetext{
"Eu... o, que eu fico mais triste, fico triste com isso e sinto um pouco de revolta com isso. Eu penso assim 'Será que eu tenho...eu tinha mesmo que tirar tudo isso, será que eu precisava mesmo', fica...aquela... pergunta suspensa, sabe... no ar. Às vezes alguém me fala 'será que você tinha que fazer isso mesmo'...Piorou, quando me falam assim, eu não queria fazer, porque eu não sentia nada...Aí o médico falou assim 'Quando você sentir, aí não adianta mais...Já tomou conta...(o câncer)' Será que não era curiosidade dele...porque...o meu é agrupamento de microcalcificação, né...e para...para ver, me, me faz...esse estrago, tira tudo isso aqui, do meu braço, porque é mortinho, gelado...” (G3).

"Eu chego a pensar, assim, que talvez... se não tivesse mexido, talvez tivesse melhor, porque antes da cirurgia, eu era bem mais animada... Aí, depois que descobriu que... que... ah! Minha vida virou de cabeça para baixo..." (G4).
}

A percepção das mudanças sofridas pelo corpo no período pós-cirúrgico, assim como a própria descoberta do câncer no momento do diagnóstico foram situações que, como expresso nos discursos acima, fizeram suscitar no grupo estudado sentimentos de revolta, tristeza e desânimo.

Mulheres com câncer de mama podem apresentar dúvidas e descontentamento quanto aos resultados da cirurgia a que foram submetidas. A falta de conhecimento sobre as opções cirúrgicas e as repercussões destas para o corpo constituem fatores impeditivos para sua participação no processo decisório de escolha do tipo de procedimento cirúrgico a ser adotado, junto aos profissionais de saúde, o que gera insatisfação, desapontamento também contribuindo para o aumento de sentimentos de tristeza, ansiedade e medo (DUARTE; ANDRADE, 2003).

O sentimento de conviver com a mastectomia pode ser traduzido por angústia, revolta e tristeza, acentuando nas mulheres com câncer de mama a percepção de que antes da cirurgia, eram mais alegres e dispostas. A tristeza é um sentimento que pode decorrer das mágoas, desprazeres e insatisfação em relação à doença e suas seqüelas (SILVA; MAMEDE, 1998). Estes sentimentos se fizeram presentes nos depoimentos apresentados pelo grupo estudado: 
“... tem dia que eu fico revoltada um pouco sim... falar que eles fizeram isso em mim... Eu sei que precisou... Mas eu fico pensando assim 'mas que coisa, que encrenca, por que'... O dia que ele (o braço) parece que está inchado eu...eu não xingo, mas tenho vontade viu... 'Diabo, que esse braço está inchado', aí eu fico um pouco revoltada...Agora, como eu falei já na outra reunião, o dia que ele amanhece fininho, eu gosto dele. Ah, eu falo assim, 'hoje ele não está inchado', ai que bom...Agora tem dia, hoje por exemplo, ele está um pouco inchado...Então eu fico um pouco revoltada, sim...Revoltada sem saber o porquê...não com a medicina, fico revoltada...assim...com a própria doença, mesmo, porque que ele...está desse jeito...Por que é que aconteceu...Aí...eu lembro dos casos que eu vejo...que são piores que o meu e tiro da minha cabeça, eu falo 'Não sou a única' e... tem caso pior do que eu...Procuro esquecer e aí... desvanece da cabeça...Mas se a gente não... levar a sério o pensamento de que outras pessoas podem estar pior, a gente fica muito ruim, né..."

“A gente vê aquele 'bração', aí, ó... dá até arrepio, ah dá, né, é impressionante, né...A gente lembra da dona (...), por exemplo, aí...” (G3).

Embora os discursos acima expostos centrem-se nos sentimentos de revolta e insatisfação das mulheres acerca da problemática vivida com o câncer de mama, sua terapêutica e os efeitos impactantes para com a aparência pessoal e funcionalidade do corpo, estas mulheres parecem aliviar-se emocionalmente ao se depararem com outras cujas seqüelas do câncer sejam consideradas como sendo mais evidentes e piores que as suas próprias (no caso, o linfedema do braço).

Os depoimentos ainda fazem transparecer que este alívio emocional não é duradouro, devido à percepção de que o braço edemaciado varie em termos de volume e tamanho, aparentando maior ou menor visibilidade às próprias mulheres e também aos outros.

As mulheres mastectomizadas estudadas por Panobianco (2002), ao reportarem-se ao linfedema do braço, o identificam como sendo um problema estigmatizante que as afligem, incomodam e assustam, fazendo-as associá-lo a uma série de atributos negativos. Nesse sentido, consideram-se como portadoras de uma marca evidente de que não se recuperaram totalmente da doença, denotando o linfedema como sendo algo que modifica seus corpos tornando-os aparentes aos seus olhos e aos dos outros, além de provocar deformidades e limitações que as levam, necessariamente, à modificação do desempenho de atividades.

De acordo com os últimos discursos expostos e, segundo Goffman (1988), o indivíduo estigmatizado, mantendo ou não uma aliança íntima com seus iguais pode mostrar uma ambivalência de identidade ao observar de perto que estes últimos comportam-se de modo a exibir os atributos negativos que lhes são imputados. 
O indivíduo estigmatizado tende a estratificar seus pares de acordo com o grau de visibilidade e imposição de seus estigmas adotando, “[...] em relação àqueles que são mais evidentemente estigmatizados do que ele as atitudes que os normais tomam em relação a ele" (GOFFMAN, 1988, p.117).

Nas falas acima, as mulheres estudadas, em contato com o grande número de mulheres mastectomizadas no REMA, com linfedema de maior volume e, portanto mais aparente, as avaliam como estando em situação pior e assim buscam conformar-se com a situação em que se encontram.

O processo de enfrentamento do câncer de mama, no grupo estudado, também foi traduzido por expressões de aceitação e conformismo diante da situação vivida em relação à doença e suas conseqüências.

As mulheres, assumindo apoiar-se em situações ou eventos considerados por elas como sendo piores que o próprio câncer, a exemplo de separação conjugal ou morte de entes queridos impossibilitados de terem sido tratados por câncer, buscaram atenuar o impacto emocional decorrente da sua doença. Parte de seus depoimentos ainda revela que a experiência de terem tido um câncer de mama não foi, necessariamente, vivenciada como uma situação problemática visto que, para o grupo estudado, a doença pode acometer qualquer pessoa:

“Eu aceito, eu não... não fico revoltada porque eu acho que isso é... coisa da vida... Porque a minha mãe teve no útero, e a minha mãe não fez o tratamento... Aí ela morreu, ela não fez o tratamento... E quando ela... morreu... Eu já tinha começado o tratamento... Eu não fiquei revoltada, assim, pensando se a minha mãe morreu, eu vou morrer também... E. eu consegui, né, o tratamento, assim... fazia... quando eu operei, fazia dois meses que a minha mão tinha morrido... Eu não me revoltei... Eu aceito... Eu acho que... aconteceram coisas piores para mim, que foi a separação... O câncer, para mim... não me atingiu não... Eu aceitei... Quando eu vim saber o resultado, eu vim sozinha... Ela falou para mim (a médica), еu... еи não fiquei preocupada”(G3).

"Eu sou conformada... o que eu sempre falo... não me desesperei... e acho que a expressão de conformismo, é uma coisa que... que está mais ou menos dentro de mim, porque eu me conformei, no começo não, mas... eu estou enfrentando bem, graças a Deus. É mais ou menos isso..." (G1).

"Eu me sinto muito feliz em estar bem, em estar com saúde, não senti nada..."

"Eu aceitei desde a primeira hora que o médico falou...Não é da boca para fora, não, é da cabeça mesmo, eu aceitei... No dia em que eu saí da sala do médico, a psicóloga me chamou para conversar...para ver como eu estava... Sei lá...Para mim está normal, se acontece com os outros por que não poderia ter acontecido comigo?" (G4). 
As mulheres, ao reportarem-se ao câncer mamário como uma situação não problemática, afirmando conformismo e aceitação frente ao diagnóstico e tratamento da doença, o fazem como estratégia para ordenar o caos vivido com o sofrimento decorrente da possibilidade e medo da morte representada pela doença e para lidar melhor com as mudanças ocorridas em suas vidas frente às repercussões do tratamento para com a imagem corporal.

As depoentes, ao utilizar a linguagem como meio simbólico para rejeitar o sofrimento vivido com a situação de portarem uma doença temida por sua característica recidivante e com forte significado existencial, apontando existir problemas piores que o próprio câncer, depositam suas inquietações em uma realidade externa a elas e aliviam-se emocionalmente. Situação a que Rodrigues (1986) concebe ser comumente encontrada em pessoas que vivenciam situações que as fragilizam, atemorizam e que lhes escapam ao controle.

O enfrentamento do câncer mamário demanda tempo para a assimilação e incorporação dos fatos e, durante este processo, as mulheres podem deparar-se com novas dificuldades, tais como a modificação de sua identidade como mulher e ainda a percepção de alterações físicas e emocionais (SILVA; MAMEDE, 1988).

Neste estudo, as mulheres assumem dificuldades vivenciadas na lida com o próprio câncer, mas também com situações emocionalmente estressantes, como a separação conjugal e a morte de entes queridos.

Entretanto, consideradas em seu conjunto, o impacto emocional do diagnóstico do câncer de mama, os efeitos adversos de suas terapias e as situações vividas pelas depoentes pareceram contribuir para o aumento da labilidade emocional do grupo estudado e para a elevação de um dos sintomas da fadiga: o comprometimento da concentração, atenção e memória recente (BONASSA, 2005).

Este aspecto emerge dos discursos:

\footnotetext{
"Ah, o que eu sinto... Eu não sei, depois que eu fiz a cirurgia... eu fiquei mais, assim... esquecida. É, esquecida... fiquei mais assim mais carente... às vezes, eu até choro."

“... parece que eu estou com um... sei lá, com memória fraca... A pessoa me fala uma coisa, daqui a pouco, eu não lembro nada...”

"Eu fiquei esquecida... Depois da cirurgia... Passou uma borracha, assim (aponta para a cabeça), em muitas coisas, incrível, eu falei para os meus filhos... que eu fiquei muito esquecida...”
} 
“Eu também... Eu não era... Tem hora que me dá um lapso, assim, na cabeça... É, assim, de relance, assim, às vezes some da cabeça aí eu... procuro... falo assim, não, eu tenho que ver como foi isso... Mas aconteceu, já... Engraçado, que eu já fiz várias cirurgias, mas só depois dessa (aponta as mamas), não sei...”

"Às vezes, eu esqueço alguma coisa, o meu marido fica bravo, né... e ele fala 'Nossa, você está ficando com a memória fraca', né...Mas...Porque é muita coisa na cabeça, é muita coisa mesmo a eu acabo esquecendo algumas.. Ele fica bravo...”

“Eu também, eu fiquei muito esquecida, às vezes os meus filhos vão sair, né...às vezes...uma semana depois vão viajar...assim...Falam o dia, tudo certinho, o lugar...Nossa Senhora, eu esqueço tudo...Aí eles vêm falar de novo, né... 'Ai, meu Deus, mas eu te falei, mãe', explicaram tudo certinho, 'Mãe eu te expliquei, eu te falei aonde eu ia, eu falei com quem eu fui', Nossa é horrível. Quando é consulta médica, assim, alguma coisa, eu marco tudo num papel, certinho, o dia, a hora, o mês... senão esqueço mesmo...É verdade.”

“Eu não sei se é da cirurgia... ou se é da anestesia... Porque quando eu fiz a segunda cirurgia (...) Eu, de manhã, não reconheci o médico... Aí eu perguntei 'Como é que o senhor se chama?' Ele falou 'Ah, Dona (...) ontem eu fiquei o dia inteiro com a senhora...' 'Eu esqueci do senhor!'.” (G2).

A presença de alterações cognitivas acima apresentadas, advindas da fadiga, faz parecer que, em certa medida, houve interferências nas relações interpessoais das mulheres, em seu contato com familiares e com profissionais da saúde.

$\mathrm{Na}$ presente categoria analítica, "Corpo e tratamento", as mulheres estudadas trouxeram a percepção sobre o próprio corpo após acometimento do câncer mamário, representando o tratamento como responsável pelas modificações provocadas na aparência pessoal. A presença de limitações físicas também figurou entre as mudanças corporais assinaladas pelo grupo estudado.

Essas alterações implicaram em um distanciamento das mulheres dos ideais sobre a imagem de corpo construídas e valorizadas na sociedade, lhes causando sentimentos de inadequação quanto à imagem corporal, visto sua incompatibilidade com tais valorações. As repercussões dessas mudanças no desempenho de atividades das mulheres estudadas serão abordadas na categoria de análise subseqüente, "Corpo e fazer". 


\subsubsection{Corpo e fazer}

As representações do tratamento por câncer mamário e suas consequiências para o desempenho das atividades das mulheres, aqui estudadas, foram apresentadas na presente categoria analítica. Estas atividades foram aqui consideradas em conformidade com as três grandes áreas de desempenho ocupacional: atividades da vida diária (AVD), atividades produtivas e do trabalho e atividades de lazer. Pertencem, a cada área de desempenho ocupacional, as seguintes unidades temáticas:

- AVD: corpo limitado na execução de AVDs; continuidade na execução de AVDs;

-Atividades produtivas e do trabalho: corpo limitado no desempenho de atividades produtivas e do trabalho; continuidade no desempenho de atividades produtivas e do trabalho.

- Atividades de lazer: limitações para a prática do lazer.

\subsubsection{Atividades da vida diária (AVDs)}

Por atividades da vida diária entendem-se tarefas e atividades relacionadas aos cuidados pessoais e à mobilidade, sendo responsáveis pela manutenção da saúde e bemestar dos indivíduos no ambiente (SUMSION, 2003; TEIXEIRA, 2003).

Baseando-se na definição de AVDs proposta pela Associação Americana de Terapia Ocupacional (AOTA, 1994), Neistadt e Crepeau (2002) as discriminam em diferentes ações e tarefas realizadas independentemente pelos sujeitos, para a sua automanutenção e interação com o meio em que vivem.

Nesta área de desempenho ocupacional (AVDs), o grupo estudado representou seu corpo limitado no processo de execução de algumas destas atividades, após tratamento do câncer mamário, que configurou a unidade temática abaixo:

\section{Corpo limitado na execução de AVDs}

-Quanto aos cuidados pessoais (arrumar-se, vestir-se, pentear-se) 
As mulheres estudadas apontaram dificuldades relevantes para com a aparência pessoal, durante o período pós-cirúrgico e na quimioterapia, quando da execução de tarefas de cuidados pessoais (arrumar-se, vestir-se e pentear-se).

Embora o grupo estudado não tenha apresentado limitações físicas com características incapacitantes no processo de realização dos cuidados pessoais, foi a partir destas atividades que as mulheres identificaram sua insatisfação com as alterações na aparência do corpo, tais como assimetria das mamas, aumento de peso corpóreo, alopecia, alterações nas unhas e odor corporal, levando-as a sentirem-se constrangidas em seus relacionamentos interpessoais.

Portanto, estas atividades de cuidado pessoal não foram discutidas nesta unidade temática, visto que as mulheres não apontaram limitações físicas que comprometessem sua independência na execução destas AVDs.

Assim, a partir dos discursos do grupo estudado, foram discutidas aqui as AVDs a que as depoentes referiram maiores dificuldades de realização: as AVDs pertencentes aos domínios da mobilidade na comunidade, comunicação funcional e expressão sexual.

\section{- Quanto à mobilidade na comunidade e comunicação funcional}

As mulheres apontaram dificuldades na execução de parte das atividades referentes à mobilidade na comunidade, ao verbalizarem interrupção na atividade de dirigir, no período pós-cirúrgico imediato e tardio:

“... fiz a cirurgia, parei de dirigir dois meses... Mas, eu percebo assim, me angustia porque não é mais aquela coisa natural, sabe?” (G1).

Reportaram-se, também, a alterações parciais nas atividades de comunicação funcional, ao assumirem dificuldades de coordenação motora e fraqueza muscular para as atividades de escrita, no período pós-cirúrgico tardio:

\footnotetext{
“Eu não consigo escrever... Eu fui copiar umas receitas e não escrevo mais que uma página. O meu braço não governa... com a caneta. Foi depois da cirurgia que está assim... porque eu escrevo, por exemplo, domingo... Eu copiava alguma coisa, umas receitas, não cheguei até o fim da página, a caneta pula da mão, não segura” (G1).
} 
Conforme apontado pelas depoentes, as limitações físicas no desempenho das AVDs acima citadas levaram-nas a sentir-se angustiadas ao perceberem seus corpos como algo não natural, também fazendo-as associar tais limitações, como consideramos, às sequielas decorrentes de seu tratamento para o câncer das mamas.

Ressaltamos que limitações físicas em mulheres com câncer mamário podem resultar de diferentes fatores, a exemplo de complicações decorrentes de intervenções terapêuticas e investigativas como lesão de nervos periféricos na cirurgia, também mialgias e neuropatias causadas por ação de quimioterápicos, entre outros.

Estas complicações físicas são passíveis de surgimento no período pós-cirúrgico imediato podendo perdurar dependendo da extensão da cirurgia e da intensidade das terapias antineoplásicas adotadas, como a radioterapia e a quimioterapia (CAPONERO; VIEIRA; TEIXEIRA, 2004; MAMEDE, 1991).

Posteriormente ao diagnóstico e à cirurgia para retirada das mamas, as mulheres podem restringir o desempenho de atividades, situação que pode lhes acentuar sentimentos depressivos e de estresse emocional (FERNANDES, 1997).

No presente estudo, as mulheres apontaram a angústia quando das limitações percebidas em seu desempenho de atividades da vida diária, situação que comumente as leva a uma condição estigmatizante, sendo rotuladas como incapazes, sem perspectiva de retorno aos padrões anteriores de atividades.

Nesse sentido, as alterações no desempenho de atividades de mulheres com câncer mamário, pela presença de limitações físicas, podem acarretar às mesmas sentimentos depreciativos, interferindo na valorização pessoal, levando-as a vivenciar este processo com grandes dificuldades, também as fazendo perceberem-se como objeto inútil diante das incapacidades identificadas por elas (ALMEIDA, 1997).

Para a Terapia Ocupacional, o sujeito, ao experimentar incapacidades físicas pode representar seu corpo como sendo dissonante do padrão vigente, visto que atributos como independência, eficiência e produtividade tornaram-se metas a serem conquistadas na sociedade contemporânea. Ao vivenciar incapacidades temporárias ou permanentes, o sujeito pode considerar-se antinatural, tornando-se um estigmatizado social, sentindo-se inadequado e fragilizado perante outros indivíduos que não apresentam seus atributos desabonadores (ROCHA, 1991). 
Este aspecto foi observado nos depoimentos das mulheres aqui estudadas, quando a percepção de limitações físicas em seu fazer foi associada, por elas, à situação de portarem corpos não naturais, gerando-lhes angústia e impotência.

No momento em que o sujeito depara-se com o fato de que seu corpo está em deficit, representa suas possibilidades ocupacionais diminuídas e uma vida que lhe escapa ao controle, levando-o a sentir-se atemorizado, incapacitado e triste. A fragilidade, representada pela falência do corpo, pode ser minorada quando o sujeito pode optar por recobrar sua autonomia e, com ela, seu autocontrole, seus desejos, sua história e seu corpo (ROCHA; MELLO, 2004).

No presente estudo, o desejo de retorno das mulheres a um padrão corporal funcional representou sua necessidade de busca pela autonomia: a retomada do controle de si, a continuidade de diálogo com uma história de vida e de ocupações alterada pela doença e também a expectativa de reassumirem papéis impossibilitados pela integridade física comprometida. No depoimento que se segue observa-se a expectativa das mulheres quanto à recuperação funcional do membro superior, ao trazerem sua percepção sobre as limitações em seu fazer:

“... a caneta pula da mão... não segura. Então eu vou levar ao conhecimento da (equipe de profissionais do REMA) como alguma coisa que eu não consiga mais (fazer)... escrevo, mas não chego a uma página... a caneta não segura” (G1).

O desconhecimento das mulheres sobre os procedimentos cirúrgicos a que foram submetidas, dos nervos lesionados durante a retirada das mamas e, principalmente, para a extirpação da rede linfática axilar pode acarretar alterações motoras.

O grupo estudado, ao trazer sua expectativa de recuperação de padrões de atividades alterados pelo tratamento do câncer mamário, representa não somente a necessidade de recuperação física, como também a retomada do senso de capacidade e utilidade. Nesse sentido, atuando para a desconstrução do rótulo estigmatizante da incapacidade conferido pelas próprias mulheres a seus corpos, pela sua percepção das diferenças funcionais pós-tratamento por câncer mamário.

\section{-Quanto à expressão sexual}


Mudanças na expressão sexual foram apontadas pelas mulheres pesquisadas enquanto uma das alterações impostas pelo corpo pós-tratamento por câncer de mama. Parte dos seus discursos aponta diminuição do desejo sexual e cansaço enquanto causas para as alterações em suas relações sexuais, especialmente após a cirurgia:

\footnotetext{
"A parte sexual é que mudou um pouco... Assim... Depois da cirurgia... Fiquei um pouco menos (ri), саіи um роисо...” (G2).

"Não sei se pode falar aqui (na oficina), mas é da parte sexual, eu estou muito cansada... (Repete justificativa dada ao marido) 'Ah, não, eu estou muito cansada, deixa quieto, estou muito cansada, deixa eu dormir' ”, (G1).

“É... se ele (o marido) não procurasse era melhor... É verdade, ai, é verdade, que coisa, né, dá até dó... Ele colabora, não procura muito, não, e quando procura... Eu não estou com vontade... é... não tenho mesmo, sinceramente, parece que esfriou mais..." (G2).

"Eu acho que, se eu tivesse um marido agora ele já teria ido embora, porque... é a última coisa que eu penso, é a ultima coisa...” (G1).

"Ah, eu sempre não tive vontade. E depois da cirurgia... Eu sou separada, né, eu agora não tenho mais nada... Eu não tinha vontade, então eu acho que foi isso que... o meu marido separou... Ele falava... desanimou...” (G2).
}

$\mathrm{Na}$ fase que se sucede à cirurgia de retirada das mamas, o exercício da sexualidade pode ser uma atividade extremamente difícil e limitante para algumas mulheres, sendo que de $20 \%$ a $30 \%$ delas podem apresentar disfunções sexuais imediatas ou tardias (CONDE et al., 2006).

Dentre os sintomas característicos de disfunções sexuais em mulheres com câncer de mama, figuram a diminuição da libido e o cansaço físico, aqui referidos pelas depoentes.

Estes sintomas podem ser atribuídos a causas fisiológicas e emocionais, como a fadiga, a ansiedade e estresse emocional, provenientes da doença e seu tratamento, do medo da morte e ainda de comprometimentos na imagem corporal independentemente da modalidade cirúrgica adotada para a extirpação do tumor. À redução da libido podem associar-se também a diminuição da função ovariana, secura vaginal, dispaurenia e dificuldades de excitação e orgasmo (CANTINELLI et al., 2006; CONDE et al., 2006; DUARTE; ANDRADE, 2003; MATHIAS, 2005).

Neste estudo, o grupo pesquisado reportou-se à cirurgia como único fator causal para a diminuição da libido e cansaço exacerbado. Ao depositar no tratamento cirúrgico a 
justificativa para a causa de seu desinteresse sexual, denota desconhecimento acerca da gênese destes sinais enquanto efeitos provenientes de diferentes causas.

Embora a literatura científica considere causas fisiológicas para explicar as disfunções sexuais em mulheres tratadas por câncer mamário, o faz, também, associandoas a causas psicológicas e emocionais sendo, a alteração da imagem corporal, uma delas. No presente estudo foi notável a insatisfação do grupo estudado com a imagem corporal modificada pelos tratamentos recebidos para o câncer de mama (cirurgia e quimioterapia).

Nesse sentido, consideramos que a insatisfação com a aparência do corpo (após excisão total das mamas, ou de parte delas, e também após o ganho de peso corporal pósquimioterapia) constituiu fator que contribuiu para a evitação das mulheres a seus parceiros, na internalidade de suas relações íntimas.

Se, em sua vida pública, as mulheres estudadas utilizam-se de recursos para ocultarem a visibilidade da mutilação do seio, a exemplo do uso de adaptações no sutiã, esta estratégia torna-se inoperante nas relações sexuais, haja vista que seus corpos ficam desnudos nestas situações, assim como o ganho de peso corpóreo, que também não pode ser disfarçado em tais ocasiões.

Assim, a evitação de relações sexuais pode vir a ser um meio das mulheres protegerem-se do olhar do companheiro. Estas observações podem ser corroboradas pela literatura científica, como nos trabalhos de Fernandes (1997) e Ferreira (1999). Para elas, a construção da sexualidade social e psicológica dá-se especialmente em referência ao corpo sendo, sua exaltação, presente no complexo cultural levando a mulher a reprimir sua sexualidade ao encontrar-se mutilada ou, também como no caso das mulheres aqui estudadas, ao sentirem-se inadequadas diante do peso corpóreo adquirido.

Em mulheres tratadas por câncer das mamas, esta repressão pode assumir diferentes formas, entre as quais a evitação de relações sexuais, devido ao constrangimento ante a exposição do corpo desfigurado aos parceiros, fazendo-as justificar a eles desinteresse sexual. As mulheres podem, ainda, reprimir-se diante de sentimentos de incapacidade para o ato sexual, visto serem as mamas os órgãos representativos da feminilidade sendo, sua ausência, vivenciada pela mulher como uma castração (FERNANDES, 1997; FERREIRA, 1999).

Hartcourt e Rumsey (2003) apontam que o processo de reelaboração da imagem corporal, em mulheres com câncer mamário, pode estender-se por períodos de tempo 
equivalentes ou pouco maiores que doze meses pós-cirurgia. Assim, em se tratando das mulheres aqui estudadas, torna-se possível considerar que sentimentos de inadequação com a imagem corporal lhes foram presentes, visto que as participantes selecionadas para este estudo se enquadraram no período de quatro a doze meses pós-tratamento cirúrgico.

Neste estudo, embora as mulheres tenham apresentado perfil diversificado quanto ao estado civil (casadas; solteiras sem companheiros; descasadas) seus depoimentos mostraram unidade quanto à percepção de seu desinteresse sexual como sendo ameaçante às suas relações afetivas. Pois, a partir da percepção de alterações sexuais como diminuição da libido e cansaço, as mulheres representaram o temor de virem a ser, ou terem sido, abandonadas pelos companheiros, conforme assinalaram em seus discursos.

Suas falas explicitam as relações sociais de gênero quando essas mulheres, diante da própria recusa em atenderem à procura sexual dos companheiros assumiram sentimentos de piedade em relação a eles. Ao negarem-se a cumprir um papel socialmente construído e esperado para elas, na relação conjugal, ou seja, o de atender incondicionalmente às necessidades sexuais dos parceiros, elas o fazem denotando culpa, pois, desse modo, deixam de corresponder às características introjetadas, por elas, da sociedade patriarcal no que concerne ao papel sexual feminino, valorizado por características como passividade e subserviência aos homens.

Nessa perspectiva, as depoentes fazem transparecer que o seu abandono pelos companheiros, concretamente vivido ou pressuposto por elas, é algo "natural", visto ser esperado em nossa cultura que as mulheres respondam prontamente aos desejos sexuais dos mesmos. Não o fazendo, é justificável que a separação do casal ocorra "naturalmente" ou, ainda, que os homens passem a procurar outras mulheres, mesmo casados.

Gradim (2005), ao referir-se ao relacionamento sexual como algo esperado dentro do casamento, aponta que o homem espera da esposa resposta à satisfação de seus desejos sexuais e, caso a mulher não lhe seja responsiva, torna-se temerosa diante da possibilidade de vir a ser traída pelo parceiro. Em seu estudo sobre vivência da sexualidade de casais que passaram pelo câncer de mama feminino, os homens relataram que, se a vida sexual do casal é insatisfatória, eles podem vir estabelecer relações extraconjugais para satisfazerem seus impulsos sexuais.

Reforçamos que, no presente estudo, as mulheres não aludiram à traição enquanto uma temeridade, mas ao abandono por parte dos companheiros. 
Se, por um lado, estas mulheres sentiram-se ameaçadas em suas relações afetivas, por outro o desinteresse e evitação sexual assumidos por elas atuaram no sentido de controlar os desejos sexuais dos companheiros, situação a que Gradim (2005) entende, em seu estudo, como sendo um exercício de poder por parte da mulher, na esfera da sexualidade. Porém, como afirma, de maneira inversa, visto que em nossa sociedade o controle da sexualidade é tido como atribuição masculina.

Nesse sentido, a noção de exercício de poder, imbricada às relações sociais de gênero se fizeram presentes na vivência da sexualidade das mulheres aqui estudadas. Pois, como defendem Louro (1997) e Scott (2000), o poder é algo em constante atividade na rede de relações sociais de homens e mulheres, não se polarizando nos termos de uns e de outros, porém atuando em diferentes vias: ora sob domínio masculino, ora feminino em uma rede que se estende em diferentes direções.

Para Gradim (2005), uma das estratégias possibilitadoras para a melhoria da vivência da sexualidade, para os casais que passaram pelo câncer de mama, seria a compreensão dos múltiplos efeitos do tratamento do câncer mamário para a mente e corpo das mulheres. Nesse sentido, a autora acredita ser o oferecimento de informações aos casais pertinente para minorar dúvidas acerca das mudanças ocorridas em seus relacionamentos, contribuindo para uma aproximação mais efetiva entre os parceiros.

Nesta unidade temática, foi apresentada a problemática vivida pelas mulheres estudadas em suas atividades da vida diária, pós-tratamento por câncer de mama. Tais dificuldades pertenceram a três domínios: mobilidade na comunidade; comunicação funcional e expressão sexual. $\mathrm{O}$ grupo estudado referiu maior funcionalidade em outros domínios de suas AVDs, ou seja: nos cuidados pessoais, na socialização e manutenção da saúde, atividades que foram abordadas na unidade temática que se segue.

\section{Continuidade na execução de AVDs}

\section{- Quanto ao cuidado pessoal (higiene pessoal, arrumar-se)}

A problemática de se ter um câncer de mama foi representada, pelo grupo estudado, sob diferentes perspectivas: quanto às formas de tratamento da doença que desfiguram, limitam e fragilizam os corpos das mulheres, restringindo-lhes sua interação com o meio e parte das AVDs; quanto à impossibilidade de sua participação no processo decisório de 
escolha do tratamento da doença, causando-lhes dúvidas quanto a seus efeitos para com a funcionalidade do corpo; ainda quanto à insegurança sobre a cura da doença visto sua característica recidivante.

Diante das questões acima, consideramos que a possibilidade das mulheres darem continuidade às atividades diárias de cuidado pessoal, de forma independente, pôde representar-lhes a reapropriação do controle do corpo, também o domínio sobre si.

A realização destas AVDs de cuidado pessoal, além de reforçar-lhes o senso de capacidade para o autocuidado, também possibilitou-lhes satisfação pessoal e a oportunidade de escolhas especialmente quando referiram-se ao vestir:

\footnotetext{
"Sobre o vestir, a gente fica mais à vontade em casa, não gosta de sofisticação, só o necessário. Se for para sair, tem que dar uma arrumadinha”.

“Eu sou igual a Dona (...). Eu me arrumo, né... Se vou sair me arrumo melhor.”

“... mas eu me arrumo normal, como se não fosse sair, porque se for, para mim, eu tenho que trocar de roupa... prefiro ficar mesmo... assim, bem à vontade.”

“Ah, eu, para mim, arrumar-se... eu não sou muito não, eu gosto de andar do jeito que eu gosto, entendeu? À vontade... se aquela roupa que eu gosto de colocar é aquela, não adianta brigar comigo...”

"Por exemplo, arrumar-se... Eu, me arrumando, é a rotina de sempre. A gente cuida da higiene, é tudo normal...”

“... higiene oral, a gente faz, né, normal... tomar banho, tomo banho de manhã e à noite.” (G2).
}

Os depoimentos acima nos levam a concordar com o que Silva e Mamede (1998) comentam sobre as atividades de autocuidado: que estas AVDs associam-se ao estilo de vida de cada mulher, às suas características de personalidade, valores pessoais, crenças, sendo dependentes de suas possibilidades de auto-controle.

\section{- Quanto à socialização}

O grupo estudado, frente à experiência das repercussões físicas e emocionais do tratamento da doença representou as atividades de socialização como um meio de dar continuidade a seu estar no mundo. São seus discursos:

"Eu participo à tarde dos movimentos do bairro... estou sempre no meio da sociedade... Sempre... Ah, eu presto apoio, né... Não mudou nada, isso aí pra mim. Gosto muito de me comunicar, eu sou muito comunicativa, sou coordenadora de grupo... Nossa, eu vou sempre, eu participo demais das coisas lá da igreja, né... Da comunidade, eu participo muito, em várias pastorais... Estou sempre em atividade, eu não paro um segundo..." (G2). 
“... ontem mesmo eu fui à congregação, nossa, eu fui tão bem recebida (pelos amigos), foi a maior força... muito legal... Quanto a isso daí, eles sabem que eu estou fazendo tratamento" (G4).

“... continuei do mesmo jeito, inclusive amigos ficaram sabendo, tinham medo de me ligar, tinham medo de ir em casa para ver...Chegavam no portão (perguntavam) 'Ela está deitada?' Não é estar deitada, eu estava normal, eles entravam e ficavam admirados. Continuei do mesmo jeito. Mas não é que estou falando da boca para fora, não, é a minha cabeça que não mudou” (G2).

Seus discursos deixaram transparecer que o estar entre amigos pode ser um facilitador no processo de enfrentamento e recuperação da doença. As mulheres, ao compartilharem com eles o fato de terem tido um câncer mamário, atenuaram a própria expectativa negativa de virem a ser estigmatizadas, situação a que Goffman (1988) denomina acobertamento.

Nesse sentido, para as mulheres estudadas, a opção pela presença de indivíduos não-estigmatizados (amigos), no lar ou em espaços públicos, lhes atenuou a expectativa de rejeição, também as auxiliando na desconstrução da representação negativa do câncer enquanto doença associada à debilidade e prostração, conforme evidenciaram seus depoimentos.

Assim, após a experiência do tratamento da doença oncológica, as relações interpessoais de mulheres com câncer de mama podem ser uma maneira de interação e de comunicação com o meio, que se desenvolvem em um processo afetivo e valorativo, favorecendo a elas condições de adquirir entusiasmo e ampliar seus horizontes (SILVA; MAMEDE, 1998).

\section{- Quanto à manutenção da saúde}

A necessidade de atender prontamente aos agendamentos de retorno médico para realização dos exames de seguimento do câncer mamário foi presente nos depoimentos das mulheres:

\footnotetext{
“... a rotina médica (refere-se ao seguimento e controle do câncer), nossa, eu faço certinho, tudo o que o médico manda eu faço certinho...”

“... a gente procura sempre estar em ordem. Segunda-feira mesmo eu cheguei na minha cidade... Meu exame já estava pronto... Eu já vi, está tudo certinho...”

“... seguir os retornos, direitinho... Não mudar (a data), a não ser quando é uma emergência, mas... Seguir direitinho os retornos..."

“... rotina médica... Eu me preocupo com ela, sim. Agora, por exemplo, lá na minha cidade, eu precisei de um médico... Eu fui, no mês oito... O médico pediu um eletro, me
} 
pediu uns exames... Até hoje eu não consegui fazer... Agora, o cardiologista foi embora, eu nem vou atrás mais...Eu fiz o papanicolau há uns quatro meses. E não fui pegar o resultado ainda... Então eu penso...Eu acho assim... ter uma rotina médica, a gente só tem aqui...(no REMA).

"Por isso que eu falo, o Rema, ele empurra a gente, porque a gente é obrigada a vir... por causa dos exercícios, e da convivência, né... Mas tirou do REMA...”

“... a gente tem que ter alguns cuidados... principalmente, os cuidados que o REMA recomenda, por causa da cirurgia” (G2).

Em suas falas, as mulheres denotam maior preocupação com o controle da doença oncológica, mesmo considerando ser importante a realização de exames preventivos a outras doenças. Ao assumirem dificuldades pessoais para a realização do seguimento e controle de doenças não relacionadas ao câncer (despreocupação com exames cardíacos; papanicolau) e reforçarem a importância do retorno médico para o controle deste último (assumem fazer seus retornos adequadamente, sem faltar), elegem o câncer de mama como foco de atenção principal, no que concerne aos cuidados com a saúde.

Como o grupo estudado se encontra no primeiro ano da doença oncológica, ainda vivencia a necessidade de eliminar o câncer, o que leva a uma preocupação centrada no mesmo. Acreditamos que, com o passar do tempo, o retorno às atividades diárias e o entendimento de que o tratamento será para o resto da vida, o comportamento das mulheres poderá ser outro.

O caráter sombrio do câncer representado pela possibilidade de sua recorrência é fator gerador de preocupação com o controle da doença, também de ansiedade e angústia em mulheres com câncer mamário. Durante os períodos que antecedem a realização dos exames de seguimento e controle da doença as pacientes podem vivenciar maior ansiedade e medo, diante da incerteza do que poderão vir a encontrar nos resultados destes exames (ALMEIDA, 1997).

No presente estudo, os exageros na alimentação configuraram respostas inadequadas à ansiedade vivenciada pelas mulheres frente às preocupações com a doença, como o temor de sua recidiva, levando-as a se sentirem inadequadas quanto à aparência do corpo, pelo conseqüente ganho de peso.

Nesse sentido, as mulheres aqui estudadas buscam nos serviços de saúde (retornos médicos e no REMA) não somente o controle do câncer, mas também alívio do estresse emocional e ainda recuperação da funcionalidade do corpo pós-tratamento de uma doença representada, por elas, nos termos de sua natureza invasiva e traiçoeira. 
Embora o REMA não agende retorno das pacientes assistidas, foi notável nos discursos das mulheres estudadas sua percepção quanto a serem "obrigadas a vir" ao referido serviço valorizando-o, nesse sentido, pelas possibilidades de recuperação integral oferecida a elas. Suas falas denotam o REMA enquanto um ponto de apoio às suas necessidades de reabilitação física (ao mencionarem os exercícios e cuidados orientados para com os membros superiores) e psicossocial (ao referirem-se à oportunidade de convivência nos grupos de apoio).

A possibilidade das mulheres participarem dos grupos de apoio e orientação desenvolvidos no REMA atua para o esclarecimento de dúvidas e para a continência de angústias vivenciadas com a doença, minorando-lhes sentimentos de solidão e desamparo frente ao diagnóstico, tratamentos e prognóstico do câncer, levando-as a sentirem-se entre "iguais", ou seja, entre pessoas que viveram experiências semelhantes.

O estar em grupos compostos por pessoas com problemática semelhante se traduz em um efeito altamente terapêutico para os participantes, pois os fazem perceber que não vivenciam seus problemas de forma isolada, também contribuindo para o compartilhamento de experiências interpessoais (VINOGRADOV; YALOM, 1992).

Estes grupos, nesse sentido, fortalecem em seus participantes um senso de capacidade para a ajuda mútua, situação que, como observamos, tem sido constante no REMA.

Se as mulheres estudadas compreenderam ser importante a participação no REMA, pela necessidade de recuperação física e psicossocial, a adoção dos cuidados para com os membros superiores, na prática de atividades no domicílio, orientados pela equipe multidisciplinar do serviço, foi vivenciada por elas de forma bastante contraditória, ora utilizando-os, ora desconsiderando-os.

Embora as mulheres tenham valorizado tais orientações em seus discursos, como sendo importantes para seu desempenho de atividades, a perspectiva de assumirem concretamente as atividades produtivas e de trabalho, adotando tais cuidados, foi representada, por elas, como sendo algo restritivo em seu processo de execução. Este aspecto foi abordado na área de desempenho subseqüente, que trata das atividades voltadas à produtividade e trabalho destas mulheres. 


\subsubsection{Atividades produtivas e do trabalho}

Por definição, as atividades produtivas e do trabalho voltam-se para a produção ou remuneração, incluindo-se aquelas não-assalariadas que contribuem para a subsistência dos indivíduos, a exemplo dos afazeres domésticos ou dos cuidados com familiares. Nesse sentido, as atividades produtivas não se configuram somente como trabalho remunerado, embora o inclua, pois são consideradas genericamente como atividades que fazem as pessoas sentirem-se úteis em diferentes contextos, como na casa, na comunidade ou mesmo no mercado de trabalho formal (KNOX, 2002; SUMSION, 2003).

No presente estudo, o grupo pesquisado representou seu corpo limitado no desempenho de atividades produtivas e do trabalho sendo, esta problemática, aqui tratada em unidade temática homônima. Estas limitações no desempenho foram associadas, particularmente, aos seguintes domínios: no controle domiciliar (aqui considerados como execução de tarefas domésticas diversas); no processo de cuidados com os outros (familiares) e na execução de trabalho remunerado.

\section{Corpo limitado no desempenho de atividades produtivas e do trabalho}

- Quanto ao controle domiciliar, cuidados com os outros e execução de trabalho remunerado

$\mathrm{Na}$ perspectiva das mulheres estudadas, as alterações no desempenho de suas atividades referentes à limpeza e manutenção da casa, assim como as do trabalho remunerado as fizeram vivenciar sentimentos de tristeza, revolta e medo, especialmente diante da possibilidade de virem a agravar ou desenvolver linfedema de braço.

Frente à expectativa frustrada de retomarem estas atividades em sua totalidade, póstratamento por câncer de mama, as mulheres representaram a cirurgia e os cuidados necessários para com os membros superiores como sendo parcialmente responsáveis pelas limitações em seu fazer, também pelos sentimentos antes mencionados, como apontaram em seus depoimentos: 
"Revolta, foi o que eu falei, a gente fica revoltada... A hora que você lembra que você não pode fazer, por causa da danada da cirurgia, então... no meu caso eu falo 'Puxa vida, se eu não tivesse passado por isso, eu...' O meu caso, né, eu fico revoltada nessa hora, a gente fica, assim, meio contrariada, fica sim”.

“Eu lembro da biópsia, da cirurgia (durante as tarefas domésticas)... revoltada eu não fico, não, eu sinto um pouquinho de... eu fico um pouco sentida, né...” (G3).

“... a gente dá conta, mas tem medo... A gente sabe que a gente consegue, mas a gente tem medo de fazer e, depois, ter conseqüências” (G1).

"A gente sabe que, se for fazer, a gente dá conta. Como eu falo, às vezes... para pegar uma panela que está mais pesada, a gente sabe que, se for pegar, a gente dá conta... Mas a gente tem medo de pegar e achar que vai prejudicar. Então a gente sabe que não pode e não pega... Mas se a gente for teimar em fazer, faz... Apesar do que a (colega de oficina) falou, o meu braço também, ele é amortecido, ele é dormente... sensação de frio. Às vezes, eu tenho a impressão que ele é mais frio que o outro. E, mesmo assim... sabendo que ele está dormente a gente sabe que se for fazer alguma coisa a gente dá conta de fazer, só que a gente não teima, né... Tem medo das conseqüências."

“Eu também concordo com ela, mas em casa... tudo, eu tenho vontade de estar fazendo mais coisas... Só que eu já tinha um medo de estar fazendo e prejudicar o braço... A cabeça quer fazer... Quer fazer, mas tem medo pensando no corpo, né..."

"A diferença é que não pode fazer (refere-se às tarefas domésticas), eu tenho que me controlar, porque senão eu vou continuar do mesmo jeito, pegar peso... aí, quando vou pegar, falo ‘não posso' então eu não pego. Se for para eu pegar eu pego a mesma coisa. Eu dou conta. Eles (a família) ficam me puxando, porque senão eu vou fazer tudo o que fazia. A costura é a mesma coisa. Eu parei, na fase da cirurgia, dispensei os clientes, mas costuro a mesma coisa" (G3).

Para Almeida et al. (2001) e Panobianco (2002), as mulheres tratadas por câncer das mamas vivenciam, de forma significativa, o temor de virem a desenvolver ou agravar o linfedema de braço, o que pode lhes restringir parte de suas atividades.

O linfedema torna-se foco de preocupação importante para mulheres com câncer mamário, devido a prejuízos funcionais nos membros superiores, que restringem o seu desempenho de atividades, e por ser representativo de seqüelas visíveis de um câncer de mama, levando-as, assim como no grupo aqui estudado, a vivenciarem sentimentos de tristeza e angústia diante destas alterações na imagem corporal.

Nas falas anteriormente expostas denota-se, em certa medida, a presença de alterações na imagem corporal do grupo estudado, especialmente ao se considerar a definição proposta por Schilder (1981) e Shearsmith (2001).

Nesse sentido, as mulheres estudadas apresentaram discrepância entre uma imagem corporal idealizada ao verbalizarem apresentar um corpo funcional para a execução de afazeres produtivos com a concretude de um corpo não responsivo a tal imagem, pelas restrições impostas pelos cuidados e pelas limitações funcionais e fadiga. Assim, representaram seus corpos como sendo limitados. 
No que concerne à adoção de cuidados com os membros superiores, foram seus discursos:

\begin{abstract}
"A gente se considera incapaz... Eu acho, porquê às vezes eu falo 'eu podia fazer isso hoje, eu não posso fazer. Hoje, eu não dou conta... dou conta, mas não posso'. Então, a gente é incapaz, muita coisa que eu fazia, não posso fazer... cheguei num limite Até antes da cirurgia, que eu não sabia que tinha o nódulo eu fazia na maior despreocupação. Depois que apareceu o nódulo e eu tive que fazer a cirurgia, mudou. Porque a gente sente, não é a mesma coisa, é completamente diferente. Mesmo que dê conta, a gente sabe que não pode. Porque eles recomendam muito evitar peso, evitar calor, então é tudo limitado" (G3).
\end{abstract}

“Torcer roupa... torcer o pano no chão, pegar peso nesse braço... Eu não faço...” (G2).

"Ah, eu estou fazendo aquilo que dá, entendeu? Por exemplo, eu tenho que fazer salgado amanhã, eu levanto de manhã cedinho, faço uma receita de salgado, aí faço meu almoço e vou indo, sabe? Lavo o banheiro, vou fazendo... vou levando...” (G3).

“... não pode estar forçando o braço, né, então, tem que tomar cuidado. Ir devagar, é isso... fazer devagar o serviço...devagar, e o que não pode ser feito...” (G2).

"Para mim, nem eu sou mais a mesma como eu era antes, não faço mais o que eu fazia, acabou. Primeiro eu virava minha casa pelo avesso, agora acabou... em relação ao trabalho, está duro" (G1).

“... antes da cirurgia, eu trabalhava muito, sabe... fazia a faxina, pegava o balde de água, hoje não... Não faço mais faxina...balde, não consigo mais pegar balde de água. Tem que ser tudo baixo, eu uso a borracha. Não subo mais escada para limpar mais, acabou. Eu, antes, virava minha casa pelo avesso.” (G2).

"Agora, a faxina é que não tem jeito né, das coisas pesadas eu não abuso... Pegar balde de água, ficar subindo em escada...” (G3).

As mulheres estudadas, além de reportarem-se à necessidade de cuidados com mãos e braços como sendo fator restritivo em seu desempenho de atividades, também se referiram à presença de limitações físicas que lhes modificaram as atividades produtivas. Em seus depoimentos, identificaram tais limitações, decorrentes do tratamento cirúrgico, como dor, diminuição da amplitude de movimentos, redução da força muscular e formigamento.

Assim, os cuidados preventivos com as mãos e braços, junto a essas limitações físicas e à necessidade de solicitarem ajuda de outras pessoas para a realização de suas atividades lhes acentuaram sentimentos de incapacidade, aspecto reforçado pelas mulheres nos seguintes depoimentos:

"Eu trabalhava para fora, acabou, não dá mais. Trabalha um pouquinho e cansa, dói o braço, não adianta teimar” (G2).

"Eu não faço a limpeza mais em casa, eu era uma pessoa muito ativa, mas hoje percebo que tenho muita dificuldade. Sinto dor no braço, dói, queima, a mama pesa” (G1).

"Às vezes a gente esquece e vai elevar o braço. E esse braço, não é que a gente não quer, não pode... E ele não tem como pegar peso, não tem jeito de você pegar com ele, ele não ajuda muito, ficou diferente." 
“O meu (braço) é todo dormente. O dia que eu pego (peso), se eu teimar em pegar peso com ele, parece que formiga, parece que tem um bichinho mordendo. Então não adianta querer fazer com esse braço, não dá”.

“Eu não faço... não faço mais, tirar a geladeira do lugar, eu peço 'me ajuda a tirar', aí eu tiro, limpo, ajudo a colocar, mas sozinha não dá mais... É pesado...E esse braço eu não forço mesmo, eu só forço o outro...Eu ajudo a tirar com o outro braço."

“A faxineira minha, é só a cada quinze dias... Mas aí eu vou manter, né, tudo no lugar... É manter, eu não esforço nada... Esforço, não...” (G3).

A fadiga, representada pelas mulheres estudadas como indisposição física e cansaço exacerbado também figurou entre as causas para as alterações em seus afazeres domésticos e de trabalho remunerado, contribuindo para a representação de um corpo limitado.

Conforme aponta Bonassa (2005), a fadiga pode levar pacientes com câncer a diminuir sua renda econômica em decorrência de redução nas atividades de trabalho remunerado, o que também pôde ser parcialmente evidenciado nos depoimentos abaixo:

\footnotetext{
"Ah, eu me sinto assim, mais cansada. Porque eu trabalho de doméstica, eu trabalhava a semana inteira e agora estou indo só dois dias no trabalho, duas vezes por semana e estou achando ruim”.

"Eu me sinto cansada, às vezes tenho que deitar. Teve um dia que eu tinha pegado roupa do varal e pus em cima da cama, né... aí eu deitei em cima da roupa, porque eu estava cansada, eu tenho que deitar” (G3).

"Ah, eu sei que depois da cirurgia, eu sinto muito canseira, muito cansaço, muita dor nas pernas. Sabe, eu tenho vontade de ficar deitada, quietinha. Do jeito que eu era...faço tricô, crochê, bordo, agora eu não tenho vontade de bordar um chinelo. Eu não tenho vontade, se pudesse ficava só deitada, lá, quietinha e não fazia nada”.

“... esse cansaço, essa indisposição, essa moleza nas pernas, eu canso... estou cansando demais, eu só sinto canseira. Agora, eu não trabalho tanto assim” (G1).
}

Diante dos sinais de fadiga, as mulheres assumiram, em seus discursos, ser necessário encontrar, durante o dia, momentos para a realização de pausa e descanso, ou mesmo trabalhar menos.

Os depoimentos que se seguem apontaram que, embora as mulheres tenham referido necessidade de descanso dos afazeres produtivos, por sentirem-se física e cognitivamente extenuadas, houve dificuldades para que isto ocorresse, efetivamente. Como verbalizaram, a realização de pausas para descanso durante o dia lhes geraram incômodo, visto não conseguirem deixar de pensar nas tarefas domésticas, a exemplo da limpeza da casa e do cuidado com os filhos: 
“... eu também me sinto esquecida e cansada. Então, dor nas pernas eu não tenho não... eu acho que tinha que descansar mais, né... trabalhar menos...” (G2).

“Nesse final de semana eu não limpei nada. Acho que, às vezes cansa fazer comida, né... ficar com a barriga no fogão, o fogo esquenta, a barriga esquenta, o braço, não tem jeito. Depois tem que lavar a louça, as pernas ficam doloridas, as costas doem, tem que ficar lá, até acabar a louça... é... cansa” (G3).

“... o que eu acho que fez eu ficar meio tontinha, não foi a cirurgia. O meu caso foi a quimioterapia. Eu não senti a cirurgia, tanto é que eu não senti, parecia que eu tinha ido lá para descansar três dias. Eu almoço e descanso um pouco, agora (após a cirurgia) eu já descanso. Então, tem que me ajudar (refere-se à filha) porque 'eu estou dormindo, estou dormindo'. Aí, eu acordo e continuo o meu serviço. Eu tenho uma filha de dez anos, ela não é muito organizada, então eu passo o dia catando brinquedo. Ela passa o dia brincando e eu catando brinquedo...” (G2).

"Durante o dia, nem pensar, não dá para deitar, você fica com o pensamento naquela coisa que tem que fazer, né... é direto assim.” (G3).

"Eu vejo que eu (no pós-cirúrgico) deitada, chazinho, almoço, delícia... Eu não tive que fazer nada, eu achei bom.” (G2).

“Eu estou me sentindo de férias, agora estou de férias (no pós-cirúrgico)...” (G3).

A oportunidade para o descanso pareceu ser-lhes possível no período de internação e no pós-cirúrgico imediato, considerados por elas como sendo um período prazeroso por terem cessado suas atividades produtivas (sentiram-se em férias, descansando), a despeito do sofrimento decorrente de terem de enfrentar a cirurgia por câncer mamário. $\mathrm{O}$ descanso também se tornou oportuno quando as mulheres justificaram, para si e para os familiares, ser necessário repousar como forma de se recobrarem das alterações físicas e emocionais provocadas pela doença (fadiga, dor, limitações físicas e estresse emocional).

Nesse sentido, a interrupção das atividades produtivas e do trabalho, para descanso, não parece ter sido uma experiência integrante dos hábitos das mulheres estudadas, pois passou a sê-la somente após a doença sendo justificadas, por elas, com uma necessidade para a recuperação da saúde.

Consideramos oportuno pontuar as atividades produtivas do grupo estudado, como predominantemente voltadas aos afazeres domésticos, atribuições consideradas, em nossa sociedade, como femininas.

As atribuições tidas como femininas, construídas em conformidade com valores de uma sociedade androcêntrica, foram forjadas a partir da ideologia da mulher biologicamente apta para a reprodução de espécies, alocando-a à internalidade do espaço doméstico, considerado, nessa perspectiva, como seu lugar característico. Neste espaço, a mulher deve exercer tarefas específicas de cuidados com o lar e com os filhos (ORTNER, 1979). 
Embora não seja possível generalizar que, atualmente, todas as mulheres compartilhem desta ideologia visto terem assumido, em espaços públicos, atividades de trabalho profissional, para muitas delas a impossibilidade de exercerem estas tarefas de cuidado com o lar e com os filhos ainda pode levá-las a sentir-se socialmente inadaptadas e incapazes, visto desconectarem-se das atribuições sociais construídas para elas, com base em valores de uma sociedade patriarcal. Nesse sentido, o sentimento de incapacidade para o exercício de afazeres domésticos pode revelar, por parte das mulheres, aspectos assimilados desta ideologia.

Acreditamos que as observações acima façam sentido, pois, diante das restrições vividas no desempenho de suas atividades domésticas, pela necessidade de adotarem os cuidados e pela presença de limitações físicas, as mulheres estudadas verbalizaram sentirem-se incapazes, o que entendemos como sendo um fator característico de sentimentos de inadequação quanto à imagem corporal, pois deixam de responder às expectativas culturalmente sancionadas para com seu papel social.

Parte de seus depoimentos ilustra estas reflexões, quando o grupo estudado refere ter tido uma "vida normal" no que tange ao desempenho de suas atividades do cuidar, antes da cirurgia:

\footnotetext{
"Eu acho diferente, porque a gente tinha uma vida normal, né, e de repente faz a cirurgia. Então sai da rotina da gente, é onde que a gente acaba cansando a cabeça, né, cansa tudo... estresse..." (G2).
}

As mulheres estudadas, ao ressaltarem viver uma "vida normal", por elas concebida como sendo a possibilidade de exercerem cuidados com o lar e com a família e atribuindo à cirurgia por câncer mamário a ruptura destas atividades, denotam valores assimilados sobre o papel feminino voltado a tais encargos. A interrupção dessas atividades fê-las sentirem-se diferentes do que eram antes da experiência da doença, reforçando sentimentos de incapacidade, também pela presença de sinais de fadiga aumentada, pós-tratamento por câncer de mama.

Em nossa sociedade, os afazeres domésticos são tidos como responsabilidade da mulher, independentemente de sua situação social, de sua posição na família e se trabalha, ou não, fora do lar. Quando estas atividades são realizadas pelas donas-de-casa, elas não são valorizadas enquanto trabalho, sendo computadas pelas estatísticas como inatividade 
econômica. Entretanto, passam a ser consideradas como trabalho quando desempenhadas por uma pessoa contratada para esse fim (geralmente mulheres), mediante remuneração em bens ou espécie, adquirindo o rótulo de emprego doméstico (BRUSCHINI; LOMBARDI, 2000; PICANÇO, 2005).

Nas décadas de 1980 e 1990, mulheres do mundo todo já enfrentavam extenuantes jornadas de trabalho profissional, ainda assumindo múltiplos papéis de trabalhadoras do lar, mães e esposas, embora a estes últimos tenha sido conferida menor valorização. Ou seja, a entrada das mulheres no mercado de trabalho profissional não as eximiu totalmente das tarefas voltadas para o cuidar (WOLF, 1992).

Esta situação é produto de uma construção social androcêntrica, amplamente questionada na internalidade dos estudos sobre gênero, acerca do papel da mulher associado especialmente ao âmbito doméstico (e, neste, sendo desvalorizado), devido à sua condição biológica voltada à reprodução e cuidados com os filhos. Mesmo sendo crítica presente nos debates sobre os papéis de gênero, observa-se que parte das mulheres traz assimilados estes valores e, quando não respondem a eles, podem vivenciar alguma estranheza quanto a seu lugar no mundo.

A dedicação da mulher ao trabalho doméstico reflete os valores tradicionais das sociedades ocidentais, por ela introjetados, pressupondo ser dela a responsabilidade pelas atividades voltadas à manutenção da vida familiar e do espaço doméstico, assim como a atenção para com os projetos individuais dos membros da família (PICANÇO, 2005).

Nessa direção, consideramos que os papéis femininos socialmente valorizados, ao sofrerem ruptura ou mudanças drásticas, como no caso das mulheres aqui estudadas, passam a ser reconfigurados e repensados por elas, inicialmente potencializando um sofrimento já vivido com a própria experiência de portarem uma doença ameaçante à vida.

As mudanças na imagem corporal e no desempenho ocupacional foram representadas, pelas mulheres estudadas, por sentimentos de incapacidade, o qual consideramos não se centrar somente na funcionalidade do corpo físico, mas também na relação deste corpo com um mundo social, que nele deposita expectativas e espera respostas.

A restrição de atividades produtivas e do trabalho, pelo surgimento de um câncer de mama e de suas terapêuticas agressivas e limitantes pode concorrer para acentuar sintomas 
depressivos em mulheres que se encontram vivendo a problemática do pós-tratamento da doença oncológica (FERNANDES, 1997).

Estas restrições podem exacerbar senso de inutilidade dessas mulheres, que já vivenciavam desvalorização de seus papéis desempenhados nos contextos do lar e do trabalho, antes mesmo de terem sido acometidas pelo câncer de mama. Assim, ao se somar a esta situação o rótulo estigmatizante da doença, as mulheres podem vir a intensificar seu sofrimento especialmente ao perceberem-se impossibilitadas de continuarem a desenvolver tais papéis (SILVA; MAMEDE, 1998).

Baseado no que foi exposto, consideramos que as mulheres, ao deixarem de ser responsivas às atividades domésticas e aos cuidados com os familiares, podem realmente desenvolver um senso de incapacidade, se a elas forem delegadas tais atividades como sendo sua responsabilidade exclusiva, fazendo atuar, nesse sentido, os valores coercitivos de uma sociedade androcêntrica, no que se refere ao desempenho dos papéis de cuidadora, exclusivamente.

Entretanto, se a elas fosse oportunizada a compreensão do fazer humano não somente associado a tais tarefas, mas também às atividades culturais, de lazer, entre outras, seria possível ampliar-lhes o campo de ação para o envolvimento em atividades mais prazerosas e significativas para si, em diferentes contextos sociais, ou mesmo, no espaço doméstico, desde que por sua opção.

Nesta unidade temática, as mulheres, ao experimentarem restrições em suas atividades produtivas por limitações físicas, fadiga e pela necessidade de cuidados com os membros superiores pós-tratamento por câncer de mama, representaram seus corpos como limitados e incapazes.

A partir desta percepção de incapacidade, as estratégias adotadas pelo grupo estudado para o resgate do senso de produtividade e, conseqüentemente, para a desconstrução do estigma relacionado à doença, foram discutidas na unidade temática que se segue. 


\section{Continuidade no desempenho de atividades produtivas e do trabalho}

\section{- Quanto ao controle domiciliar, cuidados com os outros e execução de trabalho remunerado}

$\mathrm{Na}$ unidade temática precedente, foi presente nos discursos das mulheres estudadas a percepção do próprio corpo enquanto objeto inútil.

A presença de limitações físicas pós-tratamento cirúrgico e quimioterápico, como dor, fadiga, formigamento, redução da força muscular e dos movimentos, entre outras, lhes assinalou para um corpo necessitando de descanso e de cuidados. Esta percepção lhes acentuou um sentimento de incapacidade visto restringir a realização de suas atividades produtivas e de trabalho, a exemplo dos afazeres domésticos e dos cuidados com a família.

Este grupo, ao representar seu corpo como improdutivo e limitado no processo de realização destas atividades, adotou formas questionáveis para a continuidade de seu fazer produtivo. Como mostraram seus discursos, tais práticas foram desenvolvidas à custa de excessos no trabalho, por vezes fazendo-o desconsiderar a necessidade de cuidados com os membros superiores e com os limites do corpo, pós-tratamento cirúrgico das mamas. Isto emergiu dos seguintes discursos:

\footnotetext{
"Eu desde o começo, pegava uma borracha, eu fui insistente, eu ia lá... 'Ah, não pode', mas sempre que podia eu fazia” (G1).

“... eles (familiares) não deixam eu fazer, mas eu... eu faço de teimosa, porque eles não querem que eu faça nada, eu não vou ficar parada. Mas, antes, eu costurava, eu costuro para fora, então antes eu costurava o dia todo...” (G2).

"Se não tiver ninguém perto de mim, eu faço, entendeu? Eu faço... para não levar bronca do que fiz eu falo 'foi um'(filho), depois 'foi outro'... Aí, um não pergunta para o outro e tudo bem".

"Eu procuro não fazer, não pegar peso com esse braço, mas eu faço... Empurrar com a perna, empurrar a máquina de lavar do lugar, com essa mão e a perna, ponho no lugar, ninguém sabe que fui eu que pus... pronto.” (G3).

“... eles falam que não pode passar roupa, né... Então, que nem eu, eu passo, passo só o necessário, quando eu vou sair, não fico inventando de passar roupa. Começa a esquentar o braço, eu paro”.

“Se está começando a inchar (o braço), paro...” (G2).

“Às vezes, eu vou pegar alguma coisa e esqueço. Aí, eu falo 'já foi, mesmo, já está feito'.” (G3).
} 
$\mathrm{O}$ processo de continuidade destas atividades sinalizou, para as mulheres aqui estudadas, a possibilidade de recuperação do senso de utilidade ao provarem, para si e para os outros, serem capazes de executar tarefas mesmo à custa de excessos nesse fazer, apesar de das limitações físicas, fadiga, necessidade de descanso e de cuidados, como apontado por elas, anteriormente.

Nestes discursos, as mulheres assumem que somente cessaram suas tarefas domésticas ao sentirem alterações físicas nos braços, a exemplo do aumento da temperatura e do volume dos mesmos.

Nesse sentido, a situação acima assinalada confirma o que foi explanado acerca das depoentes posicionarem-se de forma contraditória quanto à necessidade de adoção dos cuidados para com os membros superiores, sendo, esta contradição, dada pela percepção do grupo quanto a ser importante adotar os cuidados orientados no REMA, porém não o fazendo na prática, quando em contato com a família, no âmbito doméstico.

É importante salientar que os cuidados com mãos e braços não configuram às mulheres operadas, por câncer de mama, impedimentos em suas atividades, porém atentam à necessidade de um rearranjo na forma sobre como estas atividades são, por elas, desenvolvidas.

Nesse sentido, durante o desempenho dessas atividades, torna-se importante às mulheres atentar para não submeterem os braços a temperaturas elevadas, evitar exceder-se em esforços físicos, também cuidar para não sofrerem queimaduras e cortes nas mãos e braços, como forma de se prevenir o desenvolvimento do linfedema do membro superior. O que não implica, necessariamente, na cessação de suas atividades produtivas, porém em um olhar mais cuidadoso sobre o modo como as executam.

Para as mulheres estudadas, a percepção de portarem limitações e incapacidades físicas pôde ser desconstruída, quando a execução de atividades laborais, mesmo à custa de exageros, lhes fizeram sentir-se vitoriosas por terem superado obstáculos impostos em seu fazer, em decorrência destas limitações, como apontaram em suas falas:

\footnotetext{
"Tem uma coisa que a gente, depois que faz algum trabalho, a gente se sente tão vitoriosa, sabe? Fala 'nossa, eu dei conta de fazer isso, eu não... o braço não me atrapalhou'. A gente pensa isso também 'nem parece que eu dei conta de fazer aquilo...' A gente sente uma vitória, né... 'Graças a Deus que eu dei conta de fazer isso aí, meu braço não doeu’. Quer dizer que o dia que a gente dá conta, fica feliz, né...”

"A Dona (colega de oficina) falou que a gente fica feliz, que a gente faz alguma coisa e dá conta, né... Essa semana eu fui para a cidade e ao chegar fui lavar a garagem do
} 
carro. Cada dia eu lavo um lado (da casa) e encero, né... E fiquei pensando 'primeiro eu vou lavar o carro, eu não vou deixar para o meu marido lavar não... será que vou dar conta de lavar o carro e a área?' Estava perto das crianças chegarem da escola...E Eu fiquei feliz, quando eu deixei o carro limpinho e lavei a área, encerei, ficou tudo limpinho e eu dei conta, né...”

“Eu não deixo nada com eles, o que eu tenho que fazer eu faço mesmo, eu não tenho paciência, às vezes eu fico preocupada, aquilo não sai da minha cabeça...” (G3).

O fato de assumirem para si a totalidade das tarefas domésticas, por elas consideradas como extenuantes e também a opção por não solicitarem e não permitirem ajuda dos familiares (não compartilham suas tarefas com eles), nesse fazer, é algo que chama a atenção.

Ao procederem dessa maneira, externalizam a necessidade de se reapropriarem de um padrão funcional de corpo e com ele, de seus papéis como donas-de-casa e cuidadoras da família. Em seus depoimentos, a recuperação do senso de capacidade foi dado ao referirem-se vitoriosas ante a conclusão dos afazeres produtivos, provando a si mesmas serem úteis.

Nos depoimentos expostos nesta unidade temática, as mulheres também atentaram ao incômodo por elas sentido quando da reação dos familiares em não lhes permitirem a execução ou esforços excessivos nas atividades domésticas, o que lhes acentuaria, conforme consideramos, sua percepção estigmatizante da incapacidade pela impossibilidade de exercício de seus papéis dentro do lar.

Entendemos que a necessidade das mulheres estudadas em manterem-se no controle das atividades domésticas, esforçando-se sem ajuda, mesmo a contragosto dos familiares em tarefas tidas por elas como cansativas, atua para a manutenção do poder exercido, por elas, na internalidade do espaço doméstico, por meio da continuidade de seus papéis de cuidadoras, ameaçados pelo surgimento da doença, configurando em uma forma de responderem a tal ameaça.

Ao passarem pela experiência de um câncer de mama que as fragilizaram física e emocionalmente, fazendo-as necessitar de cuidados, acreditamos tornar-se problemático às mulheres estudadas permitirem-se ser cuidadas em espaços que não os dos serviços de saúde, seja solicitando ajuda dos familiares ou adotando cuidados conforme orientações oferecidas a elas, nestes serviços, a exemplo do REMA. Ao internalizarem ideais normativos sobre o cuidar como sendo atribuição feminina no âmbito familiar, torna-se 
conflitivo conceberem-se em situação oposta, ou seja, a de necessitar, no contexto doméstico, serem cuidadas restringindo suas atividades.

Outro aspecto a ser considerado, a partir dos discursos das mulheres estudadas, no que concerne às suas atividades produtivas, é que mesmo diante das restrições colocadas pelos familiares, no sentido de poupá-las de esforços que comprometeriam a integridade de sua saúde física, elas assumiram que suas potencialidades produtivas são postas à prova na ausência dos mesmos, sendo-lhes um momento propício para a continuidade de seus afazeres.

Isto, a nosso ver, configura uma estratégia para manterem-se em atividade longe do olhar avaliativo dos outros, nesse sentido, ocultando dos familiares suas seqüelas limitantes provenientes do tratamento da doença, durante o exercício de seus afazeres.

Os indivíduos que apresentam limitações físicas decorrentes de desfiguração corporal buscam aprender a estrutura da interação social a que pertencem, para reformular uma conduta que o possibilite minimizar a exposição de seu estigma. Para ilustrar essa situação de acobertamento, um indivíduo quase cego, na tentativa de restringir às pessoas a exibição de seus defeitos mais centralmente identificados com seu estigma (a ausência parcial da visão), evita ler na presença dos outros, ao temer ser, seu estigma, identificado por estes (GOFFMAN, 1988).

Nesse sentido, as limitações físicas e psicossociais decorrentes da doença e de seu tratamento predispõem as mulheres operadas a alterações no seu desempenho de atividades, tornando visível a si a aos outros a situação de ter tido um câncer de mama. Assim, se o tratamento e cuidados com a doença lhes causam restrições nas atividades domésticas, o incômodo gerado pela exposição de suas limitações aos familiares pode ser minorado caso as mulheres passem a realizar tais atividades na ausência destes últimos.

Em contrapartida, para o grupo estudado, a situação de seus estigmas serem flagrados pelos outros pode confirmar a percepção de que seus corpos se encontram limitados durante o exercício de suas atividades produtivas, visto acarretar alterações visíveis em sua rotina, conforme mostra o depoimento que se segue:

"Eu faço faxina na minha casa de sábado, né... Aí vou fazendo devagar, assim, faço com cuidado. Teve um dia que a minha filha chegou do serviço, ela falou assim 'O que está acontecendo aqui?' Eu falei 'Por quê??' Ela falou 'Você não acabou o serviço ainda' Eu falei para ela 'Eu não tenho hora para acabar, estou fazendo devagar e eu estou cansada'. Então, aí, ela não falou nada... Eu falei 'eu não tenho compromisso com 
ninguém, a hora em que eu acabar, é naquela hora mesmo' Eu estava fazendo devagar...” (G3).

Nesse sentido, as mulheres estudadas, diante da exposição aos outros das seqüelas do tratamento do câncer das mamas e de sua necessidade de cuidados, reforçaram sua percepção indesejável de portarem um corpo parcialmente disfuncional e limitado, embora continuem a exercer seu papel de poder dentro do espaço doméstico.

Em seu processo de continuidade no desempenho de atividades produtivas, as mulheres estudadas, além de exacerbarem-se em seus afazeres domésticos, também o fizeram nos cuidados com os outros, conforme verbalizaram:

\footnotetext{
"Eu tenho um sítio, é horta, é galinha, tenho um porquinho, dá um trabalho... Tem o coelho das crianças, tenho que estar cuidando, eles não cuidam, eu falo para eles cuidarem. Deixar por conta deles, eles não colocam capim, não colocam ração, não colocam água..."

“... eu cuido (da casa), não vou deixar a casa, porque se deixar... tem que dar uma varridinha sim...”

"Eu trabalho o dia todo. Eu cuido da minha casa, tenho um irmão doente, tem enfisema pulmonar. Aí eu cuido dele, tem que dar banho, faço comida para todo mundo, eu faço salgado para fora, faço bolo para fora... Então eu trabalho o dia todo, eu não paro, ontem eu trabalhei o dia todo, sem parar. Não vejo a hora de... (descansar). ”(G3).

“... eu tenho cinco pessoas em casa, três são crianças, né... Depois de tudo pronto, eles falam 'mãe, eu quero aquilo', então, tem que fazer mais alguma coisa. O que eles pedem eu faço..."

"Sabe, de ajudar os outros lá em casa, tudo é eu, você entendeu... Quando ficam doentes, quando precisam de uma coisa sou eu, então... A vida é sempre correndo atrás dos outros, mais para os outros do que para mim”.

“... eu até acho assim... eles acham que eu posso comer o que eles gostam, você entendeu, eles não podem comer o que eu gosto. Então, eu sempre tento fazer o que eles gostam, entendeu... então tem dia que eu fico meio brava por causa disso, vai, eu posso comer o que eles gostam, eles não podem comer o que eu gosto, entendeu..." (G2).
}

Estas falas novamente explicitam os papéis femininos associados às tarefas do cuidar (do lar; da família), evidenciando que as mulheres acumulam, no próprio domicílio, atividades de trabalho remunerado juntamente às tarefas supracitadas, ficando cansadas. Diante disso, as depoentes traduziram, em suas falas, a insatisfação frente à percepção de que atendem, mais freqüentemente, às necessidades dos outros do que as delas próprias.

Este último aspecto foi comentado por Almeida (1997), ao referir que mulheres com câncer mamário, ao passarem pela experiência da doença, podem se conscientizar sobre o papel predominante representado, por elas, de "ser mulher", como sendo associado às tarefas de cuidadoras da família. Assim, a dedicação da mulher ao espaço doméstico é 
passível de ser questionada, sendo tal fato resultante da situação de viver uma doença com forte significado existencial e que, muitas vezes, traz como conseqüência uma limitação física.

No presente estudo, as mulheres também vivenciaram limitações físicas de diversas ordens, que alteraram a realização das atividades produtivas.

Se, entre essas limitações, a fadiga advinda da doença foi considerada, por elas, como um sinal de atenção à necessidade de pausa e descanso durante o fazer, o que se percebe é que os exageros cometidos em suas atividades produtivas, com vistas a recuperar seu sentido de utilidade, pode contribuir para a exacerbação dos seus sintomas e para o agravo de outras limitações físicas. Isso pode predispô-las, inclusive, ao desenvolvimento ou agravo do linfedema de braço, visto as dificuldades apontadas por elas quanto à adoção de cuidados.

Diante disso, consideramos ser importante discorrer sobre possíveis motivações, além do que já foi explanado sobre o desempenho dos papéis domésticos e familiares, que atuariam como barreira para as mulheres adotarem, efetivamente, em suas atividades, os cuidados para com os braços, assim como períodos destinados a pausas e descanso durante as múltiplas tarefas produtivas e de trabalho, por elas abarcadas.

Sontag (2002), ao apontar o câncer como doença representativa, em nossa cultura, de redução de força física, de fraqueza e de falta de energia, considera a doença uma patologia da energia e, se assim concebida, confronta a expectativa das pessoas de serem produtivas dentro da sociedade atual, que valoriza as capacidades e aptidões dos indivíduos para a produtividade. Assim, o tumor tem energia, visto poder descontrolar-se e disseminar-se, mas o paciente portador de câncer não.

Nesse sentido, acreditamos que as mulheres, aqui tratadas por câncer de mama, ao assumirem para si mesmas e para as pessoas de seu convívio a interrupção de suas atividades produtivas e de trabalho, mesmo em caso de necessidade para cuidados com a saúde, conferem representatividade à doença oncológica como nos termos apontados por Sontag (2002): a de estarem fisicamente debilitadas e extenuadas corroborando-lhes a percepção negativa e estigmatizante de serem objetos inúteis, improdutivas e desvinculadas de seus papéis sociais.

Assim, pôr-se à prova no trabalho, mesmo à custa de exageros que lhes ofereçam riscos à saúde pode configurar às mulheres uma forma de atenuar os sentimentos 
incômodos advindos da representação estigmatizante sobre a experiência da doença, para si e para os outros.

Nesta unidade temática as mulheres estudadas, mesmo assumindo a necessidade de cuidados para com os membros superiores e de um olhar mais atencioso às limitações físicas provenientes da cirurgia por câncer de mama, mostraram exacerbação em suas atividades produtivas e de trabalho. Essa postura, adotada pelo grupo estudado, repercutiu de forma negativa na prática de atividades de lazer, temática abordada na área de desempenho subseqüente.

\subsubsection{Atividades de lazer}

Ferrari (2002), terapeuta ocupacional, entende por lazer as atividades praticadas pelos indivíduos em contextos que não os de produtividade e de trabalho profissional, com vistas à recreação e à diversão, assumindo existir uma inconsistência teórico-conceitual quanto à sua definição na literatura científica. Considera o lazer como fonte de criação cultural, de resgate do homem e de favorecimento da socialização, sendo parte integrante do fazer humano, junto das AVDs, das atividades produtivas e de trabalho.

A alternância entre as AVDs, o trabalho, o lazer e o descanso é considerada, na internalidade da Terapia Ocupacional, como um de seus principais indicadores de saúde, provendo aos indivíduos um equilíbrio físico e psicossocial (FERRARI, 2002; FRANCISCO, 2001; KNOX, 2002).

O lazer pode ser concebido tomando como base duas vertentes teóricas distintas. A primeira linha teórica, baseada na psicologia, concebe lazer como atividades praticadas por meio da livre escolha dos indivíduos, com vistas à obtenção de prazer, independentemente de um tempo determinado para a sua prática. A segunda vertente teórica utilizada para a concepção de lazer, baseia-se na sociologia e o considera oportuno somente quando do tempo disponibilizado pós-término de obrigações do trabalho ao final do dia, da semana, de um ano inteiro ou mesmo na aposentadoria, também das obrigações sociais para com familiares, entre outras (FERRARI, 2002).

A prática do lazer possibilita aos indivíduos o desligamento momentâneo dos problemas diários, atuando como um reparador físico e psicológico, propiciando descanso. 
Favorece, também, a participação social dos indivíduos em atividades de sua livre escolha, ampliando seu repertório de experiências culturais (DUMAZEDIER, 2000).

A definição das atividades de lazer é algo problemático, pois recai em subjetividade, uma vez que estas podem assumir uma diversidade de modalidades, sendo também dependentes dos contextos social e cultural dos indivíduos que as praticam.

Nesse sentido, Dumazedier (2000) propõe uma classificação das atividades de lazer por áreas de interesse dos indivíduos.

Assim, as atividades manuais e artísticas são tidas como práticas que possibilitam a transformação de matéria-prima em objetos utilitários e estéticos; as atividades intelectuais possibilitam a ampliação do campo de conhecimento e de informação em diferentes áreas do saber; as atividades associativas se voltam para o convívio social do indivíduo com pessoas em diferentes grupos e atividades físicas, consideradas como aquelas que possibilitam às pessoas conhecerem, em curtos períodos de tempo, novos lugares e diferentes contextos socioculturais (DUMAZEDIER, 2000).

As mulheres aqui estudadas mostraram funcionalidade questionável na área de desempenho das atividades produtivas e do trabalho, cujo processo de práticas as fizeram desafiar as limitações físicas decorrentes do tratamento do câncer mamário, assim como as restrições impostas pelos cuidados adotados nesse fazer. Essa situação atuou para a desconstrução, em certa medida, da representação de portarem corpos limitados e incapazes.

Entretanto, o excesso de trabalho por elas desenvolvido repercutiu, de forma negativa, nas práticas de lazer, por limitar o tempo disponível para tais atividades, também por elevar sinais de fadiga.

Fatores associados à experiência da doença oncológica também atuaram para o comprometimento das atividades de lazer no grupo estudado. Entre estes fatores, figuraram os próprios sinais de fadiga, a necessidade de cuidados com o corpo, o temor elevado frente à realização dos exames de seguimento da doença e a presença de sintomas depressivos, os quais, conjuntamente, alteraram suas atividades de lazer tornando-as disfuncionais nesta área de desempenho. 


\section{Limitações para a prática do lazer}

Neste estudo, o desenvolvimento de práticas de lazer foi avaliado pelas mulheres enquanto possibilidade somente após o término dos afazeres domésticos e de cuidados com a família. Atitude que reitera, nesse sentido, o que Ferrari (2002) concebe como sendo a perspectiva sociológica do lazer, ou seja, de que este pode ser oportunizado somente ao término das obrigações sociais, as quais, no gênero feminino, são efetivadas no espaço doméstico.

Parte dos depoimentos do grupo estudado revela que a oportunidade para o descanso e relaxamento somente foi possibilitada após o término das tarefas domésticas e especialmente durante os momentos em que as mulheres se encontravam sozinhas em casa:

\footnotetext{
“... durante o dia, eu tenho tempo para relaxar... Eu tenho tempo, quando eu acabo o serviço, né...”

"Para mim, quando as crianças vão para a escola, porque saem às onze e meia... Meu marido trabalha no sítio, ele vai trabalhar também, aí dá para fazer ginástica, e relaxamento... Onze e meia, meio-dia, eu estou começando...” (G3).
}

Estes depoimentos apontam, novamente, para os papéis das mulheres estudadas prioritariamente associados às atividades do cuidar reproduzindo, nesse sentido, valores sociais quanto à sua obrigatoriedade ao desempenho desses papéis culturalmente ratificados, permitindo-se ao lazer (por elas considerados como descanso, ginástica e relaxamento) somente após a consecução dos afazeres destinados ao benefício de outras pessoas (familiares).

Nesse sentido, a necessidade de períodos para descanso dos afazeres produtivos dessas mulheres acaba por colocar-se em segundo plano, visto exercerem funções em tarefas produtivas para atenderem necessidades de outras pessoas, em detrimento das suas próprias.

Isto transparece em seus discursos, ao verbalizarem poder descansar somente quando terminam seus afazeres domésticos. Situação que pode exacerbar-lhes sinais de fadiga e de estresse psicológico, também lhes causando comprometimentos na integridade da saúde física, a exemplo dos cuidados necessários com as mãos e braços, interferindo em seu processo de reabilitação. 
Outro aspecto a ser considerado refere-se aos excessos cometidos pelas mulheres estudadas no trabalho doméstico, atividade que, ao tornar-se prioritária, além de oferecer os riscos acima assinalados, pode comprometer a prática de atividades de lazer pela indisponibilidade de tempo livre, impossibilitando-lhes vivenciar o descanso, a possibilidade de recuperação física e emocional dos problemas vividos e, ainda, de desfrutarem de atividades em contextos sociais fora do espaço doméstico.

Consideramos que, no caso do grupo estudado, a ausência de investimentos em atividades de lazer de sua livre escolha, além de impedir as pausas necessárias aos cuidados com o corpo também o impossibilita de atenuar suas preocupações associadas à problemática da doença, a exemplo da ansiedade vivenciada durante os períodos de realização de exames de controle do câncer, também do estresse emocional vivido a partir da percepção de restrições em desempenho ocupacional, decorrentes de alterações físicas provocadas pelo tratamento cirúrgico, incluindo-se as alterações da imagem corporal que, neste grupo, foram significativas.

Neste grupo, a prioridade conferida ao trabalho, em detrimento do lazer e suas repercussões negativas para a saúde do corpo pôde ser evidenciado no seguinte discurso:

“... ontem mesmo, a minha filha me chamou para ir ao centro (passear), eu não fui... porque eu exagerei um pouco no sábado, na faxina... Então o braço estava doendo um pouco, eu não fui, se não eu não deixo de ir..." (G4).

As consequiências dos exageros no trabalho doméstico, tais como assinaladas na fala acima, acentuaram os sinais de fadiga nas mulheres, fazendo com que o grupo estudado, ao explanar sobre suas práticas de lazer pós-tratamento cirúrgico e quimioterápico, tenha se reportado ao cansaço físico como sendo um fator restritivo à vivência do lazer.

Embora as mulheres se reportem ao cansaço físico decorrente dos afazeres domésticos, observamos que elas não abandonam tais atividades, o que entendemos ser uma forma de exercício de poder no contexto do lar e da família.

Apesar de verbalizar interesse em desenvolver lazer em diferentes contextos que não o do espaço doméstico, o grupo representou seus corpos como estando fisicamente extenuados, justificando seu interesse em permanecer em casa. Para tanto, assumiu ser o 
descanso sua atividade de lazer preferencial, contradizendo a própria expectativa de desfrutar de lazer fora do ambiente doméstico.

Em seus discursos, as mulheres mostraram que, para permanecerem em repouso na internalidade do lar, justificaram aos familiares o fato de estarem doentes, legitimando, assim, seu desejo de repouso com base na representação de que um corpo adoecido necessita repouso para o restabelecimento da saúde:

\footnotetext{
“... eu vivo falando para os meus filhos 'ah, eu quero ver os enfeites (de natal) do shopping', o ano passado eu não fui, eu estou doida para ver... Aí, a minha filha falou 'Ah, mãe, vamos', aí eu falei 'Ah, eu não vou não, eu estou cansada...' Eu estava deitada, né, deitada assistindo televisão... 'Ah, mãe, depois você fala que você não sai, vamos, dá para nós irmos', eu falei 'não vou, estou cansada, não estou com um pingo de vontade'... Coitada, ela falou 'então vamos quinta-feira', eu falei 'então tá...' Vamos ver se vamos mesmo... estou doida para ir mas, assim, eu canso muito...”

“... eu tenho vontade, eu quero ir ver os enfeites (de natal) do shopping... mas eu não estou dando conta, eu não agüento, porque eu me sinto cansada... Eu fui à congregação e já não saí mais, quis ficar só em casa, deitada, né... Minha filha falou 'vamos, mãe' ela estava esperando para eu levá-la, tadinha... eu não quis ir, eu tenho vontade de ir, eu não dou conta... o problema é esse."

“Parece que o lazer é descansar... 'Qual o seu lazer?' 'descansar'... 'O que você vai fazer agora?’ ‘descansar....”“... é... eu estou doente, estou doente! (refere-se à justificativa dada à família para descansar)” (G4).
}

As mulheres estudadas, ao abarcarem a totalidade das tarefas domésticas que as deixam cansadas; ao assumirem diante da família uma posição de fragilidade e vitimização, justificando a necessidade de repouso por motivo de recuperação da saúde, não o assumindo como sendo por sua livre escolha; acabam por controlar as expectativas dos familiares em relação a elas, no sentido de negar-se a participar de práticas de lazer junto deles.

Nesse sentido, efetivam seu descanso por meio de estratégias de poder que as fazem evidenciar culpa, penalizando-se por não atender aos interesses da família visto distanciarem-se das atribuições culturalmente conferidas ao papel, predominantemente associadas ao cuidar.

Ao apoiarem-se na justificativa da doença para fazer prevalecer seu desejo de descanso, as mulheres empregaram outra faceta da estratégia de acobertamento, a qual possibilita às pessoas utilizarem suas características estigmatizantes, diante de conhecidos, para validar seus interesses e controlar as situações (GOFFMAN, 1988). 
Ressaltamos que, no presente estudo, a estratégia de acobertamento acima apontada foi empregada quando da possibilidade das mulheres virem a praticar lazer, não sendo utilizada de maneira idêntica na esfera das atividades produtivas e do trabalho doméstico, visto serem estas últimas as que possibilitaram às mulheres exercerem seus papéis mais internalizados e valorizados em nossa sociedade, ou seja, os de serem mantenedoras do lar e dos filhos.

No exercício dos afazeres produtivos das mulheres, o acobertamento assumiu a forma de excessos no trabalho, na ausência dos familiares, para ocultar, destes últimos, limitações físicas incapacitantes durante o fazer, evitando denunciar aspectos disfuncionais e estigmatizantes do corpo, pós-tratamento do câncer mamário, também para provarem a si mesmas serem úteis e capazes.

Neste grupo de mulheres, a atuação do acobertamento se fez novamente presente quando as depoentes, mediante justificativa de preocupações com a necessidade de cuidarem do corpo durante as atividades de lazer, particularmente da região operada e dos braços, as fizeram evitar tais práticas. Foram seus discursos:

“Ah! O que me veio de novo é... com a minha filha né... vou jogar queimada? Não posso jogar queimada... Porque a bola, a bola pode bater no meu seio, né... pode bater no meu braço... ah... brincar de correr, também não corro mais com ela, que eu posso cair e quebrar o braço...” (G4).

As reações de defesa, como as acima expostas, são comumente observadas em mulheres com câncer mamário, desde o diagnóstico da doença até fases posteriores à cirurgia, no sentido de buscarem proteger a região do corpo submetida à retirada das mamas. Esta forma de defesa pode se configurar na contração da musculatura da região escapular ou, no caso do grupo aqui estudado, pela evitação do lazer visando a proteção dos membros superiores de possíveis ferimentos que os predisponham ao linfedema do braço (PENGO; SANTOS, 2004).

Embora considerando a possibilidade de tais reações de defesa, foi notável que os cuidados apontados pelas mulheres como sendo necessários para a proteção do corpo tenham sido utilizados, por elas, como justificativa para restringirem seu lazer ao descanso, no âmbito doméstico, cuidado que não foi adotado, a contento, durante o exercício dos afazeres domésticos. 
As alterações da imagem corporal, nas mulheres estudadas, foram dadas por sua representação de um corpo fisicamente limitado e alterado em sua aparência pela mutilação das mamas e também pelo aumento do peso corpóreo. Nesse sentido, tal representação pode contribuir desfavoravelmente para a prática do lazer, neste grupo, pois, tomando como base os depoimentos apresentados nesta unidade temática, atividades como passeios e jogos com bolas exigiriam das mulheres aqui estudadas não somente habilidades físicas íntegras para a realização dessas atividades (brincar, correr) como também a exposição de seus corpos em diferentes cenários (verbalizaram desejo de visita a shoppings).

Assim, a possibilidade de realização destas atividades de lazer em ambientes fora do espaço doméstico poderia levá-las a uma exposição de seus estigmas, sob diferentes formas e em diferentes contextos. Nesse sentido, a opção por permanecerem em casa, descansando, pode configurar em uma atitude de proteção frente à possibilidade de exposição, aos outros, de seus corpos alterados.

Diante disso, reiteramos que a justificativa das mulheres para permanecerem em casa, em repouso, atua como uma forma de acobertamento de seus estigmas, o que também pode caracterizar uma necessidade de isolamento social. Este isolamento, por sua vez, foi justificado, pelo grupo estudado como algo que lhe restringiu o lazer, sendo o período de realização dos exames de controle da doença uma das justificativas empregadas para legitimar tal restrição.

Frente à perspectiva de vir a lidar com a possibilidade do retorno da doença, quando da realização dos exames médicos, as mulheres mostraram aumento da preocupação, que atuou como fator que as levaram a se desinteressar pelo lazer.

Segundo Almeida (1997), os períodos que antecedem a realização desses exames caracterizam-se pelo aumento da ansiedade e medo das mulheres, situação que, no caso do grupo aqui estudado, o fez justificar desmotivação para o lazer devido à angústia vivenciada nestas ocasiões, que ocupou lugar central em suas vidas. Seus depoimentos assinalaram para estas preocupações:

"Eu vim fazer minha mamografia outro dia, deu uma calcificação...”

“... medo, como eu estava falando com elas... Agora, agora no dia quatro eu tenho retorno, eu tenho medo de me mandarem fazer quimio, e então... a gente vai ficando encucada com as coisas e a gente não tem vontade de... de... (praticar lazer) fica só esperando o dia do retorno, para ver o que vai acontecer..." (G4). 
Ao atentarmos aos discursos das depoentes, percebemos sua representação de um corpo que lhes escapa ao controle, tornando-as vulneráveis e frágeis por centrarem suas preocupações na incerteza da cura da doença, dando visibilidade, conseqüentemente, à proximidade da morte.

Diante do que foi exposto, retomamos que a prática de atividades de lazer poderia atuar no sentido de minorar o sofrimento emocional causado pela expectativa quanto à espera da realização do retorno médico. $\mathrm{O}$ engajamento ativo das mulheres em atividades de seu interesse, baseadas em seu repertório cultural e desvinculadas da obrigatoriedade do exercício de seus papéis sociais poderia ser-lhes benéfico ao prover novas experiências relacionadas ao fazer, que não somente a do trabalho produtivo, também possibilitando formas de comunicação não centradas, somente, em questões sobre a doença.

Porém, como mostrado pelo grupo estudado, assim como para grande parte das pessoas, na sociedade atual o fazer humano é altamente valorizado na esfera da produtividade e do trabalho, ficando o lazer relegado à condição de uma atividade de menor importância, situação que decorre de complexos processos históricos associados à extrema valorização conferida ao trabalho, especialmente a partir da Revolução Industrial. Desde então, o lazer passou a ser considerado como atividade de pessoas ociosas, sendo condenado, inclusive, pela religião (FERRARI, 2002; MEDEIROS, 2003).

Neste grupo, o fato de ter de lidar constantemente com a idéia da possibilidade do retorno do câncer não somente assinala a incerteza de sua cura como acarreta às mulheres mudanças e rearranjos em sua perspectiva de vida.

A representação da proximidade da morte, provocada pelo câncer mamário, pode ser um fator disparador de mudanças consideráveis na vida de atividades das mulheres acometidas pela doença, seja em seu trabalho ou em seu lazer (DUARTE; ANDRADE, 2003).

Este aspecto foi constatado, também, no presente estudo, no que concerne à desmotivação das mulheres para o envolvimento no lazer:

“... eи achei, assim, que me aconteceu, foi que eu perdi o ânimo de tudo... Eu gostava de forró, não gosto mais... Não quero mais, já dei um basta. Tirei meus brincos, não quis mais... não é porque eu estou assim... desiludida, não, é que eu achei que o meu tempo já passou. Tirei brinco, não ponho mais nada, anel não tenho, relógio... tenho dois relógios bons, estou sem... Eu acho assim, que depois da cirurgia, só de falar que eu estou bem, que eu tirei o câncer, então, nada mais me interessa. Eu não preciso de mais nada, não preciso dançar, não preciso mais pôr nada, do jeito que estou, eu estou bem, porque o 
que eu queria era ficar livre da doença, então eu perdi esse ânimo que eu tinha, assim de sair... Eu queria ficar curada, me considero e então... para mim, já está bom. E muita coisa que eu tinha, desiludi. Eu quero é que a doença, o câncer, não volte. De que adianta eu ficar aí emperiquitada, indo para os forrós, expandindo a minha... expressão, não, eu não sou contra, é uma delícia, só que eu desanimei. Se eu chego em casa e eu estou pensando que estou com o problema (o câncer)... Então, eu acho assim é muito preferível eu não ter mais nada disso aí e também não ter mais a doença e ficar conformada com a situação."

"Ela (refere-se a uma colega de oficina) e eu, nós somos tão iguais... Que signo você é? Que lá em Termópolis (local escolhido para lazer com o grupo do REMA), eu levei roupa de banho, mas ela nem levou... Mas nós não brincamos, nem na água... Ela falou 'eu não vou entrar', eu falei 'nem eu'., (G1).

“... estava todo mundo pulando, lá na água, eu falei 'Ih, eu não vou entrar nessa água'... Ela falou 'nem eu', ela ainda fez menos que eu, ela não levou nem um boné. Aí, nós ficamos juntas, né, sentadas lá na sombra, onde ela ia eu ia... Porque as idéias batiam... Ela também estava desanimada...Eu fui, porque eu queria estar no meio do grupo, né...” (G2).

“... às vezes, não tem disposição para... para fazer as coisas, como eu já falei, eu não tenho mais aquela disposição para nada... nem para passear, nem para nada, eu não tenho... Agora não sei se foi por motivo disso aí, da doença, não sei o que é, é que me sinto assim, não tenho disposição não... agora, antes de a gente vir para cá (para a oficina), a gente estava conversando, eu falei para a (colega de oficina) 'eu viajava muito, não tenho nem vontade de viajar mais'. Eu fiquei para baixo, viu...” (G4).

Acreditamos que parte do desinteresse para a prática do lazer, para as mulheres estudadas, associou-se à natureza das atividades por elas realizadas, tais como sua participação em forrós e passeios a clubes.

Ao se considerar que passaram pela cirurgia de retirada das mamas em um período relativamente recente (menos que um ano) e, sendo-lhes presentes problemas com a imagem corporal, justifica-se sua opção por não exporem seus corpos imperfeitos ao contato com outras pessoas durante atividades de dança, ou mesmo na piscina, visto ser necessário, para esta última atividade, o uso de roupas de banho que podem revelar parte de seus corpos modificados pelo tratamento do câncer mamário.

Acresce-se a isso que as mulheres, ao assumirem seu desinteresse para o lazer, pelo fato de terem sido acometidas por uma doença ameaçante à vida, também deixaram transparecer que, no processo de enfrentamento do câncer de mama, podem surgir sintomas depressivos.

Nesse sentido, embora as mulheres estudadas verbalizem estarem conformadas com sua situação, apontam desânimo para a prática do lazer e desinteresse por cuidados relacionados à aparência física, ao referirem abandonar o uso de adornos, após o diagnóstico da doença. 
Na lida com o câncer mamário, as mulheres estudadas mostraram tendência ao isolamento do convívio social, sendo essa situação creditada, por elas, à experiência traumática da doença oncológica e representada como sendo um sinal característico de depressão:

\footnotetext{
"Eu acho que é uma coisa mesmo de dentro... ainda sábado, uma amiga minha falou 'será que você não está com depressão?', eu olhei para ela e falei 'vai, eu não estou', porque depressão, a gente nem conversa com os outros, né... Agora eu acho que deve ter uma explicação... ou decepção, que... que a gente passou pela doença..."

“... um mês depois de eu descobrir a doença, então, eu também não saio mais, eu saía, não tenho vontade mais. Esse brinco aqui, eu tenho só ele, sabe e, não deixo de me arrumar, de me pentear, de tomar banho, mas é como ela (colega de oficina), prefiro ficar em casa, eu fico quieta, no canto, pago para não sair, sair para mim é um sacrifício."

“Ah, eu também... sair, para mim, só saio porque é necessário."

“É, quando é assim... porque é um sacrifício”.

“Ah, eu também não tenho vontade de sair... Eu ia ao aniversário da tia do meu sogro, né... ela completou cem anos... fez aniversário, convidou todos os parentes, né... (O local da festa) é a um quarteirão da minha casa, e eu falei que ia, chegou na hora eu não fui, fiquei sozinha em casa... Eu falo, eu tenho vontade de sair, chega na hora aí eu não tenho mais vontade de sair...”

“... de sexta-feira, sábado e domingo, que meus filhos saem, né, que os dois têm namorada... então, aí eu me tranco lá dentro (de casa)... Sexta, sábado, domingo, nove horas da noite, eu estou trancada dentro de casa... Aí, a minha irmã liga para mim e fala 'vem aqui, eu vou passando roupa e a gente vai conversando', eu falo 'não, eu prefiro ficar'. Eu ligo o rádio bem baixinho, deito no sofá e ali eu fico, ali eu choro... E durmo, né... aí, depois, eu espero eles (os filhos) chegarem, para abrir a porta... Levanto de manhã e vou só na missa, também... e o resto do dia eu fico sozinha, prefiro ficar sozinha." (G4).
}

O diagnóstico de câncer das mamas geralmente acarreta às pacientes uma sobrecarga emocional, podendo desencadear reações de ajustamento ou mesmo ser um fator disparador de quadros afetivos, a exemplo da ansiedade e depressão, situação representada pelas participantes deste estudo (Cantinelli et al., 2006).

Frente ao sofrimento psíquico decorrente de se vivenciar uma doença com forte significado existencial e altamente temida por simbolizar proximidade com a morte, o grupo estudado, ao avaliar sua situação atual de vida como sendo sofrida e angustiante, verbalizou o desejo de recobrar seu ânimo e disposição, representando o lazer como estratégia possibilitadora para esse fim, como apontado no seguinte depoimento: 


\begin{abstract}
"Eu gostaria que fosse como era há uns dois anos atrás (anteriormente ao diagnóstico do câncer). Eu tinha disposição mesmo, nossa, se falassem que tinha gente para almoçar, num instantinho eu providenciava alguma coisa, então... eu gostaria que fosse assim... que voltasse a ser como antes, que eu era animada, agora não... Se falassem 'vamos sair?' 'vamos' 'vamos para a praia?' 'vamos'... Então, eu gostaria de voltar a ser como eu era, como eu era há uns dois anos atrás." (G4).
\end{abstract}

Observamos, no depoimento anterior, que na perspectiva do grupo estudado, o lazer foi concebido como fonte de prazer, de recuperação da energia física e psíquica, de socialização, discurso que valorizou a prática do lazer, embora o grupo tenha apresentado dificuldades para o seu desenvolvimento devido às questões explanadas nesta unidade temática.

Ao tomar como base o depoimento acima, consideramos que as depoentes, atentando à importância dos benefícios do lazer como nos termos por elas assinalados, já denota um indicativo de que sua prática pode vir a ser adotada também para o combate de sintomas depressivos, favorecendo novas oportunidades em seu fazer, ampliando suas possibilidades de interagir com o mundo. Nesse sentido, não somente por meio da reprodução de papéis voltados ao cuidar, porém, voltados para outras produções de seu interesse pessoal.

Entretanto, para as mulheres estudadas, a reprodução de seus papéis de gênero voltados aos cuidados dos outros foi algo fortemente arraigado e continuamente exercido mesmo em situações em que participaram, de forma muita próxima, da experiência do lazer, como mostraram os seguintes discursos:

\footnotetext{
"Eu também fiquei assim (refere-se ao cansaço e desânimo). Só que eu tenho uma filha de dez anos e ela está com problemas na escola, porque... Eu saía com ela duas vezes por semana, tinha uns lugares, certinho, ia ao shopping, ia ao cinema, essas coisas... Eu parei. Eu fiquei uns seis meses, acho... entre a quimio e a cirurgia. Aí ela teve problemas na escola, eu fui chamada, e eu falei, 'não, eu tenho que sair com ela...' Eu tomei essa decisão, porque eu fui à escola, cheguei lá, ela estava batendo nos meninos, ela tem dez anos e era bem tranqüila. Eu comecei a chorar na reunião da escola, minha filha batendo nas crianças ... Aí eu falei para mim, 'não, eu vou mudar', eu estava fazendo mal (em não sair com a filha). Eu não tinha vontade de sair... não conseguia sair, eu não tinha roupa que servisse, era aquela neura... O sentimento foi que...'eu vou conseguir', porque eu não tinha vontade, eu só saio para agradar minha filha.” (G1).

“Eu, às vezes, faço as coisas meio na marra, por exemplo, eu... eu não tenho vontade, como agora, no natal... Eu não gosto de sair no dia de natal, eu gosto de ficar na minha casa, mas já tem um problema porque a minha filha quer que eu vá para a casa dela. Então, muitas vezes, eu não tenho vontade, mas às vezes, eu vou... eи vou... assim, para poder contentar, para fazer a... eu acabo fazendo a vontade deles, mas por minha conta eu não iria em lugar nenhum, eu acabo indo para não contrariar. Porque, por exemplo, festa de natal, ano novo, tem que estar todo mundo junto... mas se deixar por minha
} 
conta, fico sozinha, eu como arroz e ovo e quietinha, não gosto nem de estar perto do barulho, quero ficar quietinha, eu não era assim não...então, eu acho assim... Eu, as vezes, eu falo 'não estou querendo ir, mas eu vou, porque preciso marcar presença, porque eu sou avó', né... Graças a Deus, também, quando termina tudo, né... Olha, eu dou graças a Deus quando é dois de janeiro, porque já acabou tudo (as festas de final de ano)... Às vezes, eu não estou com vontade de ir mas vou, marco presença, tudo... mas vou, porque a gente tem que fazer aquela obrigação, né... Mesmo contrariada, eu não demonstro que estou contrariada, mas vou..." (G4).

Os depoimentos acima evidenciam que as mulheres estudadas somente participaram de atividades de lazer em casos, considerados por elas, como sendo voltados à necessidade de cuidarem dos filhos e de manterem seus papéis de mães e, neste caso, também de avós. Nesse sentido, desempenhando lazer exclusivamente para atender a interesses de outras pessoas, mesmo referindo se sentirem insatisfeitas com a aparência do corpo pelo aumento do peso que lhes comprometeu o vestir, fazendo-as sentir-se expostas aos outros.

As atitudes adotadas pelas depoentes quanto à prática do lazer não foram vivenciadas como uma experiência possibilitadora de socialização ou pela oportunidade de participação em atividades em contextos fora do lar.

Suas falas traduzem sua opção por lazer para atender necessidades dos outros, o que confronta o próprio conceito de lazer apresentado por Dumazedier (2000) e Ferrari (2002): de se entendê-lo como sendo a oportunidade do indivíduo escolher atividades visando contemplar finalidades pessoais para a obtenção do prazer.

Assim, como observado nos depoimentos acima, para as mulheres estudadas não houve escolha pessoal para o exercício de seu lazer, na medida em que se colocaram na obrigatoriedade de participarem de atividades somente para a manutenção de seus papéis sociais. 


\section{CONSIDERAÇÕES FINAIS}

As representações elaboradas pelas mulheres estudadas, sobre alterações na imagem corporal, pós-tratamento por câncer das mamas, foram dadas frente à percepção de um corpo alterado interferente no desempenho ocupacional, levando-as a um distanciamento entre os ideais assimilados por elas sobre o próprio corpo, quanto à aparência e funcionalidade, com as reais possibilidades por ele apresentadas posteriormente ao acometimento da doença oncológica.

Ao buscar depreender dos discursos das mulheres as representações sociais por elas estabelecidas entre a imagem corporal de si, pós-tratamento da doença, e suas repercussões nas áreas de desempenho ocupacional, foi evidenciado que em decorrência dos tratamentos cirúrgico e quimioterápico as mulheres identificaram, no corpo, mudanças de ordem estética e funcional.

A visibilidade da mutilação parcial ou total das mamas após a cirurgia, como o aumento do peso corpóreo, a alopecia, a fadiga e o linfedema de braço sinalizaram às mulheres a necessidade de lidar com seqüelas visíveis da doença, o que lhes coloca em contato permanente com a situação de portarem uma doença temida por sua cronicidade e, ainda, atentarem ao modo como o corpo se apresenta para elas e para outros nas diferentes áreas de desempenho ocupacional.

A presença de limitações físicas foi, também, vivenciada de forma problemática, tendo sido representada por redução da força muscular e da amplitude de movimentos, dor, entre outras alterações, restringindo o desempenho ocupacional das mulheres estudadas.

As mulheres, ao se depararem com alterações na aparência pessoal e limitações físicas, vivenciaram sentimentos de fragilidade e revolta, visto trazerem marcas corporais concretas que se confrontaram com a imagem de corpo mentalmente idealizada, desconstruída pelo tratamento do câncer, embora tenham, também, apontado conformismo ante a experiência vivida com a doença.

O processo de lidar com tais sentimentos, a partir da representação de um corpo alterado, as fez questionar as condutas adotadas pelas equipes de saúde quanto à omissão de informações acerca da natureza da cirurgia a que foram submetidas e a extensão de seus resultados que, ao causarem prejuízos estéticos e funcionais inesperados, acentuou nas mulheres sentimentos de inadequação com a imagem corporal. 
Os efeitos colaterais do tratamento da doença, na perspectiva das mulheres estudadas, tornaram seus corpos diferentes dos de outras mulheres.

Não corresponder aos padrões e valores normativos construídos com base em uma sociedade masculina, sobre como se deve ser o corpo feminino, levou o grupo estudado a vivenciar o câncer como uma doença estigmatizante.

Parte desses valores, orientados para o papel produtivo da mulher exclusivamente voltado ao exercício de funções na internalidade do lar e dos cuidados com os outros foram determinantes para as mulheres, pós-tratamento da doença, terem reforçado o estigma de incapacidade, pelas restrições impostas em seus afazeres, decorrentes das seqüelas do tratamento cirúrgico e devido à necessidade de cuidados.

A partir dessas representações sobre a imagem do corpo pós-tratamento, as mulheres verbalizaram restrições em parte das atividades da vida diária, especialmente nos domínios da mobilidade na comunidade, na comunicação funcional e expressão sexual, o que abre extensas possibilidades para a atuação de terapeutas ocupacionais e outros profissionais de saúde com essa clientela, diante da complexidade da problemática assinalada.

Em contrapartida, a possibilidade de realização das AVDs, relacionadas aos cuidados pessoais, à socialização e à manutenção da saúde, denotaram a necessidade das mulheres de reassumirem o domínio sobre o próprio corpo, assim como a busca pelo controle da doença oncológica.

Nessa representação, apontaram o REMA como sendo importante em suas vidas, pelas possibilidades oferecidas a elas para a reabilitação física e psicossocial, assim como pelas orientações e informações técnicas oferecidas pelo serviço, sobre a doença e seus cuidados, embora na prática diária tenham assumido dificuldades de seguí-las.

Nesse sentido, o grupo estudado, ao vivenciar restrições durante a execução de seus afazeres domésticos e de trabalho, assumiu sentir-se incapaz frente às limitações impostas pelo corpo e pela necessidade de cuidados.

Ao sentirem-se expostas aos outros, durante suas atividades produtivas, as mulheres adotaram estratégias para continuidade dessas atividades, de forma questionável, arriscando a integridade física e emocional, sobrecarregando-se com afazeres por elas como assumidos responsáveis, exclusivamente, a si. 
A exacerbação nos afazeres domésticos, neste grupo, significou a possibilidade de desconstrução do estigma de se portar uma doença crônica, incapacitante, debilitante e temida, embora tenha contribuído para a elevação da fadiga e de alterações físicas como o aumento do volume e da temperatura dos braços, ainda atuando para a manutenção de papéis sociais destinados, predominantemente, ao cuidar.

Nesse sentido, aproximou-o de um estado de "normalidade" em que a reprodução de papéis, tidos como femininos, foi reforçadora da idéia do lugar da mulher no espaço doméstico, impedindo visibilidade e compreensão do grupo quanto a esses papéis serem uma estratégia manipuladora para a manutenção dos valores androcêntricos, que as colocam em desvantagem social constituindo, ainda, fatores impeditivos para um processo de reabilitação efetivo e necessário, após o câncer de mama.

Assim, o olhar do terapeuta ocupacional e outros profissionais de saúde, para esta situação vivida pelas mulheres, torna-se necessário para auxiliá-las a descobrir novas formas para a continuidade adequada de suas atividades produtivas.

O lazer, para o grupo estudado, foi inviabilizado por questões de ordem emocional também associadas ao estigma da doença, fazendo com que as mulheres apresentassem desmotivação para a sua prática, somente o fazendo para atender a interesses de familiares, denotando necessidade de manterem seus papéis sociais, embora a contragosto.

Diante do que foi exposto, a avaliação da imagem corporal em mulheres com câncer mamário, é relevante para a identificação das diferentes expectativas e valorações das mesmas quanto à aparência pessoal, funcionalidade do corpo e suas repercussões no fazer, buscando auxiliá-las para a estruturação de uma rotina mais adequada às necessidades físicas e psicossociais.

Este estudo dá visibilidade, para terapeutas ocupacionais e para outros profissionais atuantes com mulheres com câncer de mama, sobre os desdobramentos do fazer humano em suas múltiplas possibilidades, seja para o cuidado próprio, para a produtividade e para o lazer. O equilíbrio entre essas áreas de ação humana são importantes para a manutenção ou recuperação da saúde física e psicossocial das mulheres tratadas por câncer mamário, provendo um senso de controle e apropriação sobre o próprio corpo, base do seu fazer.

A busca por esse equilíbrio no desempenho de atividades é algo que se deve tomar em conta nos processos de práticas de reabilitação pós-cirurgia, pois, como visto neste estudo, as mulheres pesquisadas, ao enfatizarem a realização de suas atividades produtivas que lhes possibilitam o exercício de seus papéis de cuidadoras, não vislumbram outras 
áreas do fazer humano que lhes dêem oportunidade de escolhas pessoais, conhecimento de si e prazer, o que, como acreditamos, facilitaria o processo de enfrentamento da doença. 


\section{REFERÊNCIAS}

ABRIC, J. C. A abordagem estrutural das representações sociais. In: MOREIRA, A. S. P.; OLIVEIRA, D. C. (orgs.) Estudos interdisciplinares de representação social. Goiânia: AB, 1998. p.27-38.

AFONSO, L.; PINTO, M. C. V. A oficina como um grupo aberto: a experiência do grupo cinco. In: AFONSO, L. (org.). Oficinas em dinâmica de grupo: um método de intervenção psicossocial. Belo Horizonte: Edições do Campo Social, 2002. p. 109-116.

AL-GHAZAL, S. K.; FALLOWFIELD, L.; BLAMEY, R. W. The psychological impact of immediate rather than delayed breast reconstruction. European Journal of Surgical Oncology, v.26, p.17-19, 2000.

ALMEIDA, A. M.; MAMEDE, M. V.; PANOBIANCO, M. S.; PRADO, A. S.; CLAPIS, M. J. Construindo o significado da recorrência da doença: a experiência de mulheres com câncer de mama. Rev. Latino-am Enfermagem, v.9, n.5, p.63-69, 2001.

ALMEIDA, A. M. Vivendo com a incerteza da doença: a experiência de mulheres com câncer de mama. 1997. 153 f. Tese (Doutorado em Enfermagem)- Escola de Enfermagem de Ribeirão Preto, Universidade de São Paulo, Ribeirão Preto, 1997.

ALVES-MAZZOTTI, A. J. O planejamento de pesquisas qualitativas. In: ALVESMAZZOTTI, A. J.; GEWANDSZNADJER, F. O método nas ciências naturais e sociais: pesquisa quantitativa e qualitativa. 2. ed. São Paulo: Pioneira, 2001. p.147-176.

AMARAL, L. A. Integração social e suas barreiras: representações culturais do corpo mutilado. Revista de Terapia Ocupacional USP, v.2, n.4, p.188-195, 1991.

ANADON, M.; MACHADO, P. B. Representações sociais: origem do estudo e conceituação. In: __ Reflexões teórico-metodológicas sobre representações sociais. Salvador: Ed. UNEB, 2001. p. 9-32.

ARRUDA, A. Teoria das representações sociais e teorias de gênero. Cadernos de Pesquisa, n.117, p.127-147, novembro 2002.

BARDIN, L. Análise de conteúdo. 3. ed.Tradução Luiz Antero Reto; Augusto Pinheiro. Lisboa: Edições 70, 2004. 223p.

BOGDAN, R.; BIKLEN, S. Investigação qualitativa em educação. Porto: Porto, 1994. 336p.

BONASSA, E. M. A. Fadiga. In: BONASSA, E. M. A.; SANTANA, T. R. Enfermagem em terapêutica oncológica. 3.ed. São Paulo: Editora Atheneu, 2005. p. 203-213.

BRASIL. Conselho Nacional de Saúde.

http://conselho.saude.gov.br/resolucoes/1996/Reso196.doc 
BRASIL. Ministério da Saúde. Instituto Nacional do Câncer. Disponível em: http://www.inca.org.br/cancer/tipos/mama.html. Acesso em: 20 de julho de 2002.

BRASIL. Ministério da Saúde. Instituto Nacional do Câncer. Disponível em: http://www.inca.org.br/cancer/tipos/mama.html. Acesso em: 3 de junho de 2006.

BREDIN, M. Mastectomy, body image and therapeutic massage: a qualitative study of women's experience. Journal of Advanced Nursing, v.29, n.5, p.1113-1120, 1999.

BRUSCHINI, C. LOMBARDI, M. R. A bipolaridade do trabalho feminino no Brasil contemporâneo. Cadernos de Pesquisa, n. 110, p. 67-104, julho 2000.

CANTINELLI, F. S.; CAMACHO, R. S.; SMALETZ, O.; BRAGUITTONI, E.; RENNÓ JUNIOR, J. A oncopsiquiatria no câncer de mama: considerações a respeito de questões do feminino. Rev. Psiq. Clín., v.33, n.3, p.124-133, 2006.

CAPONERO, R.; VIEIRA, D. E.; TEIXEIRA, M. J. Dor no paciente com câncer. Prática Hospitalar, ano VI, n.35, set/out 2004. Disponível em: http://www.praticahospitalr.com.br/pratica\%2041/pgsmateria\%2032-41.html. Acesso em: 1 setembro 2006.

CARNEIRO, F.; AGOSTINI, M. Oficinas de reflexão: espaços de liberdade e saúde. In: AGOSTINI, M; D’ACRI, V.(orgs.) Trabalho feminino e saúde. Rio de Janeiro: FIOCRUZ ENSP, 1994. p.53-83.

CARRILO, O.; JAVIER, F. Rehabilitación integral posmastectomia. Cir. Gen., v.19, n.3, p.220-226, 1997.

CHIESA, A. M. Mulher, corpo e agravo à saúde: do ingênuo ao crítico através do conhecimento. In: FONSECA, R. G. S. (org.) A mulher e cidadania na nova ordem social. São Paulo: Núcleo de Estudos da Mulher e Relações Sociais de Gênero, 1996. p.129-150.

CLAPIS, M. J. Qualidade de vida de mulheres com câncer de mama - uma perspectiva de gênero. 1996. 252 f. Tese (Doutorado em Enfermagem)- Escola de Enfermagem de Ribeirão Preto, Universidade de São Paulo, Ribeirão Preto, 1996.

CONDE, D. M.; PINTO-NETO, A. M.; FREITAS JÚNIOR, R.; ALDRIGHI, J. M. Qualidade de vida de mulheres com câncer de mama. Rev Bras de Ginecol Obstet., v.28, n.3, p.195-204, 2006.

CORREIA, M. I. T. D. Perda de peso em pacientes com câncer e seu impacto no tratamento. Revista Prática Hospitalar, ano VII, n.41, set/out 2005. Disponível em: http://www.praticahospitalar.com.br/pratica\%2041/pgs/materia\%2029-41.html. Acesso em: 1 setembro 2006.

COSTA, L. J. M.; VARELLA, P. C. S.; GIGLIO, A. Weight changes during chemotherapy for breast cancer. São Paulo Medical Journal/ Revista Paulista de Medicina, v.120, n.4, p.113-117, 2002. 
DINIZ, N. M. F.; LOPES, R. L. M.; ALMEIDA, M. S.; GESTEIRA, S. M. A.; OLIVEIRA, J. F. Psicodrama como estratégia pedagógica: vivências no ensino de graduação na área de saúde da mulher. Rev. Latino-am Enfermagem, v.8, n. 4, p.88-94, agosto 2000 .

DUARTE, T. P.; ANDRADE, A. N. Enfrentando a mastectomia: análise dos relatos de mulheres mastectomizadas sobre questões ligadas à sexualidade. Estudos de Psicologia, v.8, n.1, p.155-163, 2003.

DUMAZEDIER, J. Sociologia empírica do lazer. São Paulo: Perspectiva, 2000. 244p. (Debates, 164).

DURKHEIM, E. As regras do método sociológico. Tradução Pietro Nassetti. São Paulo: Martin Claret, 2002. 157p.

EARLY, M. B. Desempenho ocupacional. In: PEDRETTI, L. W.; EARLY, M. B. Terapia ocupacional: capacidades práticas para disfunções físicas. Tradução Lúcia Speed Ferreira de Mello, Cláudio Assencio Rocha. São Paulo: Roca, 2004. p. 125-131.

ETCOFF, N. A lei do mais belo: a ciência da beleza. Tradução Ana Luiza Borges de Barros. Rio de Janeiro: Objetiva, 1999. 369p.

FARR, R. M. Representações sociais: a teoria e sua história. In: GUARESCHI, P.; JOVCHELOVITCH, S. (orgs.). Textos em representações sociais. 8. ed. Petrópolis: Vozes, 1995. p.31-59.

FERNANDES, A. F. C. O cotidiano da mulher com câncer de mama. Fortaleza: PósGraduação/ DENF/ UFC/ Fundação Cearense de Pesquisa e Cultura, 1997. 96p.

FERRARI, M. A. C. Lazer e ocupação do tempo livre na terceira idade. In: PAPALEO NETTO, M. Gerontologia: a velhice e o envelhecimento em visão globalizada. São Paulo: Editora Atheneu, 2002. p. 99-105.

FERREIRA, M. L. S. M.; MAMEDE, M. V. Representação do corpo na relação consigo mesma após mastectomia. Rev. Latino-am Enfermagem, v.11, n.3, p.299-304, maiojunho 2003.

FERREIRA, M. L. S. M. Vivenciando os primeiros meses de pós-mastectomia: um estudo de caso. 1999. 145 f. Tese (Doutorado em Enfermagem)- Escola de Enfermagem de Ribeirão Preto, Universidade de São Paulo, Ribeirão Preto, 1999.

FERREIRA, S. L.; NASCIMENTO, E. R. Grupos de autoconsciência: uma alternativa para educação em saúde da mulher nos serviços de saúde. Femina, v.5, p.451-454, 1992.

FRANCISCO, B. R. Terapia ocupacional. 2.ed. Campinas, São Paulo: Papirus, 2001.

FREIRE, P. Pedagogia da autonomia: saberes necessários à prática educativa. São Paulo: Paz e Terra, 1996. 148p. 
FRIES, A.; REINHARD, G. The impact of mastectomy on dimensions of psychological and psychosocial experience and behaviour in affected women. Rehabilitation, v.35, n. 1, p.54-64, 1996.

FUNG, K. W.; LAU, Y.; FIELDING, R.; OR, A.; YIP, A. The impact of mastectomy, breast- conserving treatment and immediate breast reconstruction on the quality of life of chinese women. ANZ J. Surg., v.71, p. 202-206, 2001.

GIGLIO, A. A quimioterapia por câncer de mama engorda? Rev Assoc Med Bras, São Paulo, v.50, n.3, p.238, 2004.

GOFFMAN, E. Estigma: notas sobre a manipulação da identidade deteriorada. 4.ed. Rio de Janeiro: Guanabara Koogan, 1988. 158p.

GOLDENBERG, M. A arte de pesquisar: como fazer pesquisa qualitativa em ciências sociais. Rio de Janeiro: Record, 1997. 107 p.

GRADIM, C. V. C. Sexualidade de casais que vivenciaram o câncer de mama. 2005. 182 f. Tese (Doutorado em Enfermagem)- Escola de Enfermagem de Ribeirão Preto, Universidade de São Paulo, Ribeirão Preto, 2005.

HARTCOURT, D.; RUMSEY, N. Psychological aspects of breast reconstruction: a review of the literature. Journal of Advanced Nursing, v.35, n.4, p.477-487, 2001.

HARTCOURT, D.; RUMSEY, N.; AMBLER, N. R.; CAWTHORN, S. J.; REID, C. D.; MADDOX, P. R.; KENEALY, J. M.; RAINSBURY, R. M.; HARRY, C. The psychological effect of mastectomy with or without breast reconstruction: a prospective, multicenter study. Plastic \& Reconstructive Surgery, v.111, n.3, p.1060-1068, march 2003.

HECKERT, U. Reações psíquicas à mastectomia. H.U. Rev., v.21, n.1, p.97-102, 1995.

HERZLICH, C. A problemática da representação social e sua utilidade no campo da doença. Physis- Revista de Saúde Coletiva, v.1, n.2, p.23-34, 1991.

HINMAN, M. R. Factors influencing work disability for women who have undergone mastectomy. Women and Health, v.34, n. 2, p. 45-60, 2002.

ISHIKAWA, N. M.; DERCHAIN, S. F. M.; THULER, L. C. S. Fadiga em pacientes com câncer de mama em tratamento adjuvante. Revista Brasileira de Cancerologia, v.51, n.4, p.313-318, 2005.

JUNQUEIRA JUNIOR, G.; QUADROS, C.; SANTOS, A. C. Protocolo para prevenção do linfedema pós- mastectomia: uma proposta. Rev. HCPA \& Faculdade de Medicina da Universidade Federal do Rio Grande do Sul, v.8, n. 2, p. 9-12, 1988.

KNOX, S. H. Avaliação da recreação e lazer. In: NEISTADT, M. E.; CREPEAU, E. B. Willard \& Spackman: terapia ocupacional. 9. ed. Rio de Janeiro: Guanabara Koogan, 2002. p.195-201. 
KRYNSKY, S. Reações psicológicas e psicopatológicas relacionadas à cirurgia da mama. Bol. CEPP, v.4, n. 2, p. 59-65, 1986.

LEME, M. A. V. S. O impacto da teoria das representações sociais. In: SPINK, M. J. (org.). O conhecimento no cotidiano: as representações sociais na perspectiva da psicologia social. São Paulo: Brasiliense, 1995. p.46-57.

LOURO, G. L. Gênero, sexualidade e educação: uma perspectiva pós-estruturalista. Petrópolis: Vozes, 1997. 179p.

MALUF, M. F. M.; MORI, L. J.; BARROS, A. C. S. D. O impacto psicológico do câncer de mama. Revista Brasileira de Cancerologia, v.51, n.2, p.149-154, 2005.

MAMEDE, M. V. Reabilitação de mastectomizadas: um novo enfoque assistencial. 1991. 140 f. Tese (Livre Docência em Enfermagem) - Escola de Enfermagem de Ribeirão Preto, Universidade de São Paulo, Ribeirão Preto, 1991.

MAMEDE, M. V.; CLAPIS, M. J.; ALMEIDA, A. M.; PRADO, M. A. S.; MEIRELLES, M. C. C., BIFFI, R. G.; PANOBIANCO, M. S.; GOMES, F.; KEBBE, L. M.; KANEHIRA, A. S.; SCHERER, E. A.; RODRIGUES, L. M. Manual de orientação para mulheres com câncer de mama. Ribeirão Preto: S.P., 1999.

MAMEDE, M. V.; CLAPIS, M. J.; PANOBIANCO, M. S.; BIFFI, R. G.; BUENO, L. V. Orientações pós mastectomia: o papel da enfermagem. Rev. Bras. Cancerol., v.46, n.1, p.57-62, 2000.

MATHIAS, C. O impacto do diagnóstico e tratamento do câncer de mama na função sexual. Revista Prática Hospitalar, ano VII, n.41, set/out 2005. Disponível em: http://wwwpraticahospitalar.com.br/pratica\%2041/pgs/materia\%2032-41.html. Acesso em: 1 setembro 2006.

McPHAIL, G.; WILSON, S. Women's experience of breast conserving treatment for breast câncer. European Journal of Cancer Care, v.9, p.144-150, 2000.

MEDEIROS, M. H. R. Terapia ocupacional: um enfoque epistemológico e social. São Carlos: EdUFSCAR, 2003. 185 p.

MELO, E. M.; ARAUJO, T. L.; OLIVEIRA, T. C.; ALMEIDA, D. T. Mulher mastectomizada em tratamento quimioterápico: um estudo dos comportamentos na perspectiva do modelo adaptativo de Roy. Revista Brasileira de Cancerologia, v.48, n.1, p.21-28, 2002.

MINAYO, M. C. S. Pesquisa social: teoria, método e criatividade. 19. ed. Petrópolis: Vozes, 2001. $80 \mathrm{p}$.

O desafio do conhecimento: pesquisa qualitativa em saúde. Rio de Janeiro: Hucitec-Abrasco, 1999. 270p. 
O conceito de representações sociais dentro da sociologia clássica. In: GUARESCHI, P.; JOVCHELOVITCH (orgs.). Textos em representações sociais. 8. ed. Petrópolis: Vozes, 1995. p.89-111.

MOSCOVICI, S. A representação social da psicanálise. Tradução de Álvaro Cabral. Rio de Janeiro: Zahar Editores, 1978. 291 p.

MURARO, R. M.; BOFF, L. Feminino e masculino: uma nova consciência para o encontro das diferenças. Rio de Janeiro: Sextante, 2002. 288p.

NEISTADT, M. E.; CREPEAU, E. B. Introdução à terapia ocupacional. In: Willard \& Spackman: terapia ocupacional. 9. ed. Rio de Janeiro: Guanabara Koogan, 2002. p.3-9.

NÓBREGA, S. M. Sobre a teoria das representações sociais. In: MOREIRA, A.S.P. (Org.) Representações sociais: teoria e prática. João Pessoa: Ed. Universitária, 2001. p. 55-87.

O que é representação social. Paris: Ècole des Hautes en Sciences Sociales, 1990. /Mimeografado/

OLIVEIRA, F. O. F.; WERBA, G. C. Representações sociais. In: STREY, M. N. et al Psicologia social contemporânea: livro-texto. Petrópolis: Vozes, 2001. p. 104-117.

ORTNER, S. B. Está a mulher para o homem assim como a natureza para a cultura? In: ROSALvO, M.Z.; LAMPHERE, L. A mulher a cultura a sociedade. Tradução Cila Ankier; Rachel Gorenstein. Rio de Janeiro: Paz e Terra, 1979. p.95-120.

PANOBIANCO, M. S. O significado do linfedema na vida de mulheres com câncer de mama. 2002. 137 f. Tese (Doutorado em Enfermagem)- Escola de Enfermagem de Ribeirão Preto, Universidade de São Paulo, Ribeirão Preto, 2002.

Acompanhamento dos três primeiros meses pós-tratamento cirúrgico do câncer de mama: estudo das complicações e intercorrências associadas ao edema de braço. 1998. 94 f. Dissertação (Mestrado em Enfermagem)- Escola de Enfermagem de Ribeirão Preto, Universidade de São Paulo, Ribeirão Preto, 1998.

PEDRETTI, L. W.; EARLY, M. B. Desempenho ocupacional e modelos de prática prática para disfunção física. In: PEDRETTI, L. W.; EARLY, M. B. Terapia ocupacional: capacidades práticas para disfunções físicas. Tradução Lúcia Speed Ferreira de Mello, Cláudio Assencio Rocha. São Paulo: Roca, 2004. p. 3-13.

PENGO, M. M. S. B.; SANTOS, W. A. O papel do terapeuta ocupacional em oncologia. In: DE CARLO, M. M. R. P.; LUZO, M. C. M. (orgs.) Terapia ocupacional: reabilitação física e contextos hospitalares. São Paulo: Roca, 2004. p. 233-255.

PICANÇO, F. S. Amélia e a mulher de verdade: representação dos papéis da mulher e do homem em relação ao trabalho e à vida familiar. In: ARAÚJO, C.; SCALON, C. (orgs.) Gênero, família e trabalho no Brasil. Rio de Janeiro: Editora FGV, 2005. p.149-172. 
PRADO, M. A. S. Aderência a atividade física em mulheres submetidas a cirurgia por câncer de mama. 2001. 108 f. Dissertação (Mestrado em Enfermagem) - Escola de Enfermagem de Ribeirão Preto, Universidade de São Paulo, Ribeirão Preto, 2001.

ROCHA, E. F. Corpo deficiente: um desvio da norma? Revista de Terapia Ocupacional USP, v.2, n.4, p.182-187, 1991.

ROCHA, E. F.; MELLO, M. A. F. Os sentidos do corpo e da intervenção hospitalar. In: DE CARLO, M. M. R. P.; LUZO, M. C. M. (orgs.) Terapia ocupacional: reabilitação física e contextos hospitalares. São Paulo: Roca, 2004. p.29-46.

RODRIGUES, J. C. Tabu do corpo. 4. ed. Rio de Janeiro: Dois Pontos Ed., 1986. 174p.

SÁ, C. P. Representações sociais: o conceito e o estado atual da teoria. In: SPINK, M. J. (org.). O conhecimento no cotidiano: as representações sociais na perspectiva da psicologia social. São Paulo: Brasiliense, 1995. p.19-45.

SALES, C. A. C. C.; PAIVA, L.; SCANDIUZZI, D.; ANJOS, A. C. Y. Qualidade de vida de mulheres tratadas de câncer de mama: funcionamento social. Rev. Bras. Cancerol., v.47, n.3, p.263-272, julho-agosto-setembro 2001.

SASAKI, T.; LAMARI, N. M. Reabilitação funcional precoce pós mastectomia. HB Cient., v.4, n.2, p.121-127, 1997.

SCHIERONI, M. P.; CARLONE, M.; REVELLO, M. P.; CANE, L.; CAMPAGNOLLI, M. Serratus anterior muscle palsy after mastectomy: rehabilitative considerations. Europa Medicophysica, v.31, n.2, p.83-88, 1995.

SCHILDER, P. A imagem do corpo. Tradução de Rosanne Wertman. São Paulo: Martins Fontes, 1981. 316 p.

SCHNEIDER, I. J. C.; LOPES, S. M. S.; FURTADO, C. M. R. Fadiga relacionada o câncer. Revista Prática Hospitalar, ano VI, n.35, set/out 2004. Disponível em: http://www.praticahospitalar.com.br/pratica\%2035/paginas/materia\%2007-35.html. Acesso em: 1 setembro 2006.

SCOTT, J. W. El género: una categoria útil para el análisis histórico. In: LAMAS, M. (org.) El género: la construcción cultural de la diferencia sexual. México: PUEG, 2000. p. 265-302.

SHEARSMITH, F. K. The management of altered body image: a role for occupational therapy. British Journal of Occupational Therapy, v. 64, n. 8, p.387-392, 2001.

SHIMOZUMA, K.; GANZ, P. A.; PETERSEN, L.; HIRJI, K. Quality of life in the first year after breast cancer surgery: rehabilitation needs and patterns of recovery. Breast Cancer Research and Treatment, v.56, n.1, p.45-57, 1999.

SILVA, V. C. E. O impacto da revelação do diagnóstico de câncer na percepção do paciente. 2005. 218 f. Dissertação (Mestrado em Enfermagem)- Escola de Enfermagem de Ribeirão Preto, Universidade de São Paulo, Ribeirão Preto, 1997. 
SILVA, R. M.; MAMEDE, M. V. Conviver com a mastectomia. Fortaleza: UFC, 1998. $155 \mathrm{p}$.

SONTAG, S. A doença como metáfora. Tradução Márcio Ramalho. Rio de Janeiro: Edições Graal ltda. 2002. 108p.

SPINK, M. J. O estudo empírico das representações sociais. In: (org.). $\mathbf{O}$ conhecimento no cotidiano: as representações sociais na perspectiva da psicologia social. São Paulo: Brasiliense, 1995. p.85-108.

O conceito de representação social na abordagem psicossocial. Cad. Saúde Pública, Rio de Janeiro, v.9, n.3, p.300-308, jul/set 1993.

SUMSION, T. Perspectiva da prática baseada no cliente. In: Prática baseada no cliente em terapia ocupacional. Tradução Vagner Raso. São Paulo: Roca, 2003. p.1-24.

SVATICS, E. Rehabilitation of breast cancer patients. Lege Artis Medicine, v.8, n.10, p.664-668, 1998.

TAVARES, M. C. G. C. F. Imagem corporal: conceito e desenvolvimento. Barueri, São Paulo: Manole, 2003. 147 p.

TEIXEIRA, E. Atividades da vida diária. In: TEIXEIRA, E.; SAURON, F. N.; SANTOS, L. S. B.; OLIVEIRA, M. C. Terapia ocupacional em reabilitação física. São Paulo: Roca, 2003. p.194-219.

TULMAN, L.; FAWCETT, J. A framework for studying functional status after diagnosis of breast cancer. Cancer Nurs, v.13, n. 2, p. 95-99, 1990.

TURA, L. F. R. Representações coletivas e representações sociais: notas introdutórias. In: TURA, L. F. R; MOREIRA, A. S. P (orgs.). Saúde e representações sociais.João Pessoa: Editora Universitária/ UFPB, 2004. p.15-27.

TURA, L. F. R.; MOREIRA, A. S. P. (orgs.) Saúde e representações sociais. João Pessoa: Editora Universitária/ UFPB, 2004. 253p.

UNIVERSIDADE DE SÃO PAULO. Escola de Enfermagem de Ribeirão Preto. Rema. Disponível em: http:// www.eerp.usp.br/rema/index1.html. Acesso em: 1 de junho de 2006.

VINOGRADOV, S.; YALOM, I. D. Manual de psicoterapia de grupo. Tradução Dayse Batista. Porto Alegre: Artes Médicas, 1992. 215p.

VOCKINS, H. Occupational therapy intervention with patients with breast cancer: a survey. European Journal of Cancer Care, v.13, p.45-52, 2004.

WOLF, N. O mito da beleza: como as imagens de beleza são usadas contra as mulheres. Tradução Waldéa Barcellos. Rio de Janeiro: Rocco, 1992. 439p. 
WOLFF, L. R. Rede de suporte social da mulher mastectomizada. 1996. $187 \mathrm{f}$. Dissertação (Mestrado em Enfermagem)- Escola de Enfermagem de Ribeirão Preto, Universidade de São Paulo, Ribeirão Preto, 1996.

YALOM, M. História do seio. Tradução Maria Augusta Júdice. Lisboa: Teorema, 1998. $364 p$. 


\section{ANEXO A}
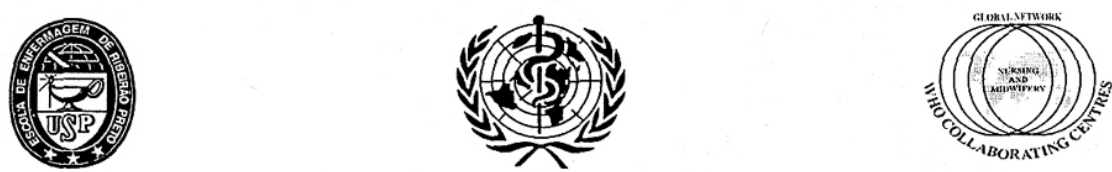

ESCOLA DE ENFERMAGEM DE RIBEIRÃO PRETO - UNIVERSIDADE DE SÃO PAULO CENTRO COLABORADOR DA ORGANIZAÇÃO MUNDIAL DA SAÚDE PARA

O DESENVOLVIMENTO DA PESQUISA EM ENFERMAGEM

Avenida Bandeirantes, 3900 - Campus Universitário - Ribeirāo Preto - CEP 14040-902 - São Paulo - Brasil FAX: 55 - 16 - 633-3271/55 - 16 - 630-2561 - TELEFONES: 55 - 16 - 633-0379/602-3382

\section{COMITÊ DE ÉTICA EM PESQUISA DA EERP/USP}

Of.CEP-EERP/USP - 064/2005

Ribeirão Preto, 19 de maio de 2005

Prezada Senhora,

Comunicamos que o projeto de pesquisa, abaixo especificado, foi analisado e considerado APROVADO pelo Comitê de Ética em Pesquisa da Escola de Enfermagem de Ribeirão Preto da Universidade de São Paulo, em sua $75^{\circ}$ Reunião Ordinária, realizada em 18 de maio de 2005.

Protocolo: $\quad n^{\circ} 0535 / 2005$

Projeto: O fazer mediado pelo corpo: oficinas de reflexão com mulheres mastectomizadas na perspectiva da terapia ocupacional

Pesquisadores: Ana Maria de Almeida (Orientadora) Leonardo Martins Kebbe (Doutorando)

Em atendimento à Resolução 196/96, deverá ser encaminhado ao CEP - relatório final da pesquisa e a publicacão de seus resultados, para acompanhamento, bem como comunicada qualquer intercorrência ou a sua interrupção.

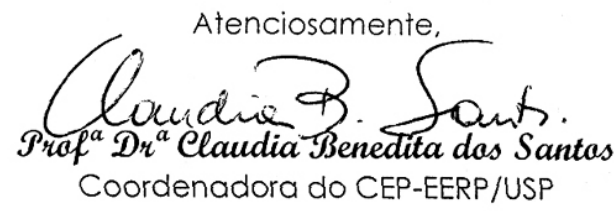

$\| m^{a} . S r^{a}$.

Prof $^{\circ}$ Dr $^{\circ}$ Ana Maria de Almeida (Orientadora)

Departamento de Enfermagem Materno-Infantil e Saúde Pública Escola de Enfermagem de Ribeirão Preto - USP 


\section{APÊNDICE - B}

\section{TERMO DE CONSENTIMENTO LIVRE E ESCLARECIDO}

Prezada

Convido você a participar desta pesquisa, intitulada "O fazer mediado pelo corpo: oficinas de reflexão com mulheres mastectomizadas na perspectiva da terapia ocupacional", sob orientação da Prof ${ }^{a}$. Dr ${ }^{a}$. Ana Maria de Almeida, do Departamento de Enfermagem Materno Infantil e Saúde Pública da Escola de Enfermagem de Ribeirão Preto da Universidade de São Paulo. Essa pesquisa pretende compreender como você percebe o seu corpo após a cirurgia para retirada da mama, como esse sentimento interfere nas suas atividades diárias e de que formas você se utiliza para manter as atividades de seu interesse.

Esse assunto será discutido em 4 encontros grupais com outras mulheres que realizaram a mesma cirurgia. Estes encontros grupais terão duração de aproximadamente 1 hora e 30 minutos e não te causará risco algum.Se você concordar em participar, sua participação será filmada e suas respostas gravadas, e suas falas serão identificadas por um nome escolhido por você. As fitas gravadas ficarão arquivadas com o registro das oficinas e as datas em que ocorreram. Essas fitas serão utilizadas apenas para o registro de dados da pesquisa e só terão acesso a elas os pesquisadores envolvidos.

Sua participação não é obrigatória, ou seja, você decidirá pela sua participação ou não neste estudo.

A você será dado o direito de desistir em qualquer momento da pesquisa, sem precisar apresentar justificativas para essa desistência. Essa desistência não fará com que você seja prejudicada em nenhum atendimento dentro deste serviço.

A participação nas oficinas não implicará em custos adicionais porque serão realizadas nos mesmos dias e horários de atendimento do serviço.

Você terá informações e esclarecimentos atualizados durante sua participação neste estudo e os pesquisadores assumirão o compromisso de que você será devidamente acompanhada e assistida durante todo o período de sua participação neste projeto, bem como será garantida a continuidade do seu tratamento, após a conclusão dos trabalhos de pesquisa.

Tenho ciência do exposto acima e desejo participar desta pesquisa como forma de contribuir com o responsável que subscreve este documento.

Ribeirão Preto, de

de

PARTICIPANTE

\section{PESQUISADOR RESPONSÁVEL} Leonardo Martins Kebbe

Aluno do Programa de Doutorado em Enfermagem em Saúde Pública da Escola de Enfermagem de Ribeirão Preto da Universidade de São Paulo.

Endereço do pesquisador: Avenida Caramuru no 2100 apto.831- Bairro República, Ribeirão Preto, SP. CEP: 14030-000- Tel(16) 3620 3849. E-mail: kebbe@uol.com.br 
APÊNDICE- A

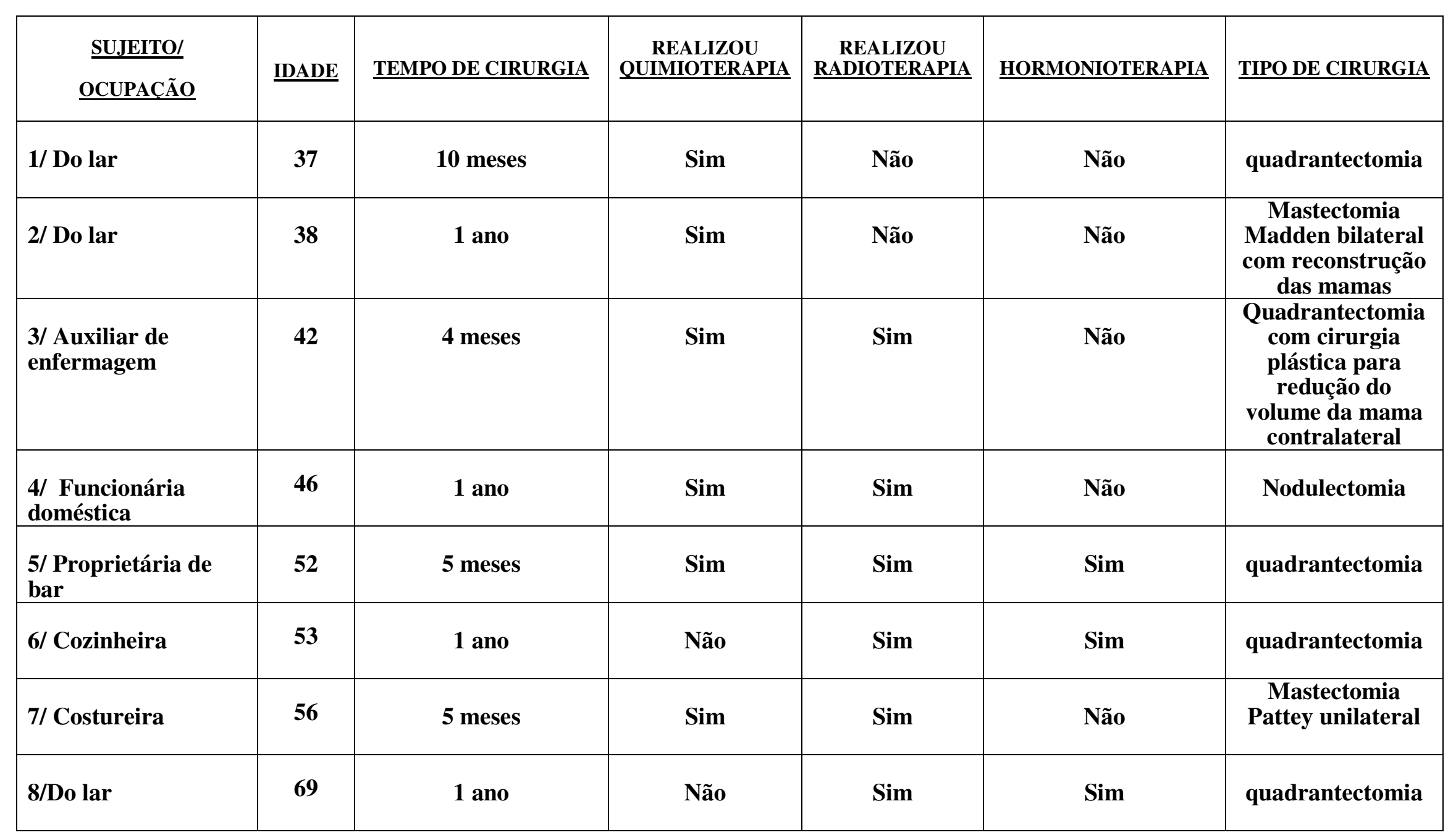


